\title{
HoofDSTUK VII
}

\section{Naar een tempel aan het Koningsplein (1861-1867)}

Aan het genootschap was door oprichter Radermacher in 1779 een woonbedrijfspand aan de Grote Rivier geschonken. Het kreeg een kant en klaar genootschapshuis en museum in de schoot geworpen. Raffles had in 1814 van een nieuw gebouw achter de sociëteit de Harmonie de bestemming veranderd. In plaats van winkels en eethuizen te huisvesten, was het pand aan de Rijswijkstraat onderdak gaan bieden aan het genootschap. De periode die we nu bespreken, wordt gemarkeerd door de bouw van een eigen, als museum en genootschapshuis ontworpen gebouw. Dat nieuwe gebouw zou een einde maken aan een lange reeks problemen en het genootschap de mogelijkheid bieden zich verder te ontplooien, niet meer geremd door een te kleine en slechte behuizing. Met voldoende ruimte konden eindelijk de collecties in hun volle omvang worden getoond. Het publiek kon gestimuleerd worden om te komen kijken. Het genootschap, dat zich beroemde op zijn ouderdom en op de publicaties, kon nu proberen aan het publiek te tonen dat die reputatie ook door de collecties gedragen werd.

De niet zo vlotte bouwgeschiedenis domineert dit tijdperk dat echter evenzeer andere belangrijke wapenfeiten telt: grotere aandacht voor de oudheden, aandacht voor de inheemse talen, uitbouw van de collectie etnografica en tenslotte een stabilisering van het publicatiebeleid. In zeven jaar verschenen vier delen Verhandelingen, zeven jaargangen van het Tijdschrift en vijf bundels Notulen van vergaderingen, een nieuwigheid. We kunnen met recht zeggen dat het genootschap in 1867 volgroeid was. Het kon in een eigen gebouw aan de bloeiperiode beginnen, waarop nog steeds de reputatie van de organisatie is gefundeerd: de jaren 1868-1950. Omdat de interessante bouwgeschiedenis en de ingebruikneming van de nieuwe 'tempel' tevens het einde van dit tijdperk kenmerken en het begin van een nieuw, komt dat aspect aan het eind van dit hoofdstuk aan de orde. Eerst kijken we naar de organisatie zelf en naar de zojuist genoemde wapenfeiten. 


\section{Een bestuur van ambtenaren}

Aan het begin van de hier beschreven periode werden de bestuurszetels in de Rijswijkstraat verdeeld tussen militairen en ambtenaren. Aan het eind van dezelfde periode, toen die zetels aan het Koningsplein waren neergezet, hadden de ambtenaren het heft in handen. Bij deze verschuiving verdwenen in betrekkelijk korte tijd twee soorten bestuursleden uit beeld, die in het verleden nogal prominent aanwezig waren: de predikanten en de militaire geneeskundigen. De verschuiving valt samen met de grotere bureaucratisering en het toenemen van bestuurstaken door de overheid. De instelling in Batavia van departementen van bestuur kreeg in 1866 haar beslag. Toen werd ook het Departement van Onderwijs, Eeredienst en Nijverheid ingesteld dat zich in het vervolg ook met de zaken van taal-, land en volkenkunde, kunsten en wetenschappen, kortom met het genootschap, zou bezighouden. In plaats van brieven van de eerste gouvernementssecretaris, kreeg het bestuur de overheidspost voortaan van de directeur van dat nieuwe departement.

Op 1 januari 1861 waren tien van de elf bestuursplaatsen bezet. Twee generaals hadden de leiding: voorzitter was de opperbevelhebber van het leger, J. van Swieten, terwijl G. Wassink, hoofd van de Geneeskundige Dienst, vice-voorzitter was. Thesaurier was de hoofd-intendant van de militaire administratie, J.J. van Emmerik. De andere militairen waren de genie-officier Versteeg en de oud-luitenant-ter-zee G.F. de Bruijn Kops, directeur van het Bataviase Prauwenveer. De enige predikant in het bestuur, J. Brumund, was al wel terug van zijn Europees verlof, maar hij zou pas in mei 1861 zijn plaats opnieuw innemen. Meer dan bovengenoemde militairen was hij om zijn kennis van de oudheidkunde en taal- en volkenkunde in het bestuur gekomen, al werd Versteegs naam wel genoemd in verband met het maken van de oudheidkundige kaart. Wassinks aanwezigheid leek er meer een van traditie: zijn voorgangers bij de dienst Fritze, Godefroij en Bosch hadden ook in het bestuur gezeten. Een machtig voorzitter als de legeraanvoerder gaf het genootschap aanzien. Hem kon niet gemakkelijk iets geweigerd worden.

De hoogste ambtenaar-niet militair in 1861 was het lid van de Raad van Indië, jhr. H.C. van der Wijck. De hoofdcommiezen bij de Algemene Secretarie, Netscher en Van der Chijs, de griffier van de beide gerechtshoven, Der Kinderen en tenslotte oud-geografisch-ingenieur G.A. de Lange completeerden de groep ambtenaren. Van dezen had Netscher zich sinds zijn intrede in het bestuur (1855) zeer verdienstelijk gemaakt. Hij zou echter spoedig verhuizen naar zijn nieuwe standplaats in Riouw. Van der Chijs en Der Kinderen, de laatste nog geen jaar in het bestuur, zouden zich voor veel zaken inzetten.

Kijken we naar het bestuur op 1 januari 1868, dan wordt de verschuiving zichtbaar. Vier personen hadden de acht jaar overleefd: naast Der Kinderen 
en Van der Chijs aan het hoofd, waren dat De Lange en De Bruijn Kops. De nieuwelingen waren Levyssohn Norman (1862) en W. Stortenbeker (1862), de eerste hoofdcommies, de laatste commies bij de Algemene Secretarie, verder de commies bij de Faktorij, N.P. van den Berg (1863), het lid van de Raad van Indië, Alexander Loudon (1864) en de conrector van het gymnasium Koning Willem III, L.W.G. de Roo (1865). In 1867 kwamen daar nog bij het lid van de Rekenkamer J.S. van Coevorden en tenslotte het hoofd van het Topografisch Bureau, A.W. Egter van Wissekerke, een oud-militair. Het tableau de la troupe laat duidelijk zien dat de ambtenaren de militairen nagenoeg hadden uitgeschakeld. Alleen De Bruijn Kops en Egter van Wissekerke hadden een militair verleden.

Na het vertrek van Van Swieten in augustus 1862 was Wassink voorzitter geworden. Met diens dood in november 1864 verdween de laatste militair van de voorzitterszetel. Hij werd opgevolgd door Alexander Loudon, tot dat moment gewoon lid, die zelf in 1868 in Batavia zou overlijden. Vice-voorzitter Der Kinderen, procureur-generaal van het Hooggerechtshof, nam toen de voorzittershamer over, die hij negentien jaar zou vasthouden, een record in de genootschapsgeschiedenis.

\section{De relatie met de overheid}

Deze lijst met namen en functies dient niet zo zeer een behoefte aan volledigheid, als wel ter adstructie van de hiervoor genoemde verschuiving. $\mathrm{Na}$ de dood van Brumund kwam er geen nieuwe predikant in het bestuur, er werden geen particulieren voorgedragen. De kunstenaars Van Kinsbergen en Raden Saleh werden geen bestuurslid. Er was geen plaats voor journalisten in het bestuur. De hierboven niet genoemde namen - er waren 24 bestuursleden in de besproken periode, sommigen waren weer snel verdwenen - waren personen die dit beeld niet aantasten. De overmacht van ambtenaren van de Algemene Secretarie met hun collega's, onder aanvoering van twee leden van de Raad van Indië, waarborgde een goed contact met het gouvernement, zonder welke het genootschap niet kon leven. De jaarlijkse subsidie van $f 8.000$ verzekerde het voortbestaan van het genootschap, dat anders failliet was gegaan. De bouw van het museum-genootschapsgebouw op gouvernementskosten, zorgde ervoor dat de afhankelijkheid van het genootschap van het gouvernement nog groter werd. Dat ten tijde van de opening van het museum zeven van de elf bestuursleden ambtenaren van het gouvernement waren, naast twee oud-militairen, een onderwijsman en een faktorij-beambte, geeft duidelijk aan dat de band tussen gouvernement en genootschap weer net zo hecht was als ten tijde van de oprichting (1778). Soms was die ook wel eens nauwer dan men van een formeel zelfstandige organisatie ten opzichte 
van zijn subsidiegever zou verwachten.

Andere factoren versterken nog de indruk van de grote overheidsbetrokkenheid. De ambtenaar voor het Javaans, Cohen Stuart, erelid en conservator voor de oosterse handschriften, was geen bestuurslid maar woonde wel bijna alle bestuursvergaderingen bij. Hij formuleerde voor het genootschap belangrijke adviezen aan het gouvernement, zijn werkgever, onder andere over taalen onderwijsbeleid. Het moet voor het toekijkende publiek steeds minder duidelijk zijn geweest, dat het genootschap zelfstandig was, gedragen door leden, die het bestuursoptreden tijdens de algemene vergaderingen mochten bevragen. Dat gebeurde dan ook nauwelijks. De algemene vergaderingen werden niet door een grote groep leden bezocht en het bestuur had een aantal taken van weleer, zoals het benoemen van nieuwe leden, aan zich getrokken. Deze bijeenkomsten hadden dan ook meer het karakter van verslaggeving dan van verantwoording afleggen. Na 1866 duurde het vijf jaar voor er weer een algemene vergadering werd belegd. Van het betrekken van de leden bij een openingsceremonie van het nieuwe gebouw in 1867, blijkt niets. Dit bevestigt het beeld van een semi-overheidsinstelling die een aantal taken uitvoert, waarvoor in de bestuursstructuur van het gouvernement in Batavia anders geen orgaan zou zijn. Het beheer over een museum en het verzorgen van publicaties op het gebied van de taal-, land- en volkenkunde behoorden daartoe. Het kon tevens contacten onderhouden met organisaties in de regio en in Europa, waarvoor anders het secretariaat van het gouvernement en later het Departement van Onderwijs ambtenaren had moeten aanstellen. Als het genootschap de hoofden van gewestelijk bestuur aanschreef met het verzoek om opgaven te sturen voor de oudheidkundige kaart, om gegevens over etnografica, om een woordenlijst ingevuld terug te krijgen, voor hoeveel van de betrokkenen was het dan niets anders dan de verlengde arm van het gouvernement of de arm van het gouvernement zelf?

\section{Het bestuur en de leden}

Het bestuur besloot over het lidmaatschap van nieuwe leden, terwijl het zelf ook besloot over de voordrachten voor het opvullen van open plaatsen in de eigen gelederen. De leden, die nog steeds veertig gulden lidmaatschapsgeld per jaar betaalden, speelden een marginale rol. Soms leek het wel dat hun belangrijkste functie was om die bijdrage te voldoen en de publicaties in ontvangst te nemen. Hoeveel van de leden lazen de Verhandelingen, het Tijdschrift, de Notulen? Was voor het merendeel van hen het lidmaatschap niet eenvoudig iets dat erbij hoorde, waar men als ambtenaar niet goed onderuit kon? Een vrijbuiter als Van der Tuuk hoefde zich van zo iets niets aan te trekken. Hij werd geen lid toen hij in Indië was, al werd hij in 1866 wel verkozen 
tot corresponderend lid, toen hij tussen zijn bezoeken aan Sumatra en Bali in een aantal jaren in Amsterdam verbleef. Het aantal leden dat een actieve rol speelde buiten het bestuur, was zeer beperkt. In de laatste jaren waren het Holle, Riedel, Netscher (oud-bestuurslid), Cohen Stuart en Raden Saleh.

In 1861 had het genootschap 358 leden. In 1853 waren dat er 341 geweest. Van die leden betaalden in 1861 alleen de 184 gewone leden binnen NederlandsIndië de contributie. De 25 honoraire leden, de 109 corresponderende leden en de 34 gewone leden buiten Nederlands-Indië (verlofgangers) betaalden die niet. De zes buitengewone leden betaalden evenmin contributie (TBG 12:160). De kernleden waren de gewone leden in Nederlands-Indië, 193 bij de aanvang van 1868. Dat wees op een vrij stabiel ledental. Weliswaar waren er ieder jaar vrij veel afzeggingen, er kwamen ook steeds genoeg nieuwe leden bij. In 1866 meldde het bestuur aan de algemene vergadering dat het 20 leden had verloren en dat er 35 nieuwe leden bij waren gekomen (Notulen 4:139). Dat verlies werd verklaard door overlijden of vertrek naar patria.

De leden, het bestuur, het waren ook in de periode 1861-1867 in grote meerderheid Nederlandse mannen, die als ambtenaar of militair in Batavia of de buitengewesten werkzaam waren. Een lijstje van de nieuwe Indonesische leden in deze jaren is snel gegeven:

1863 Radhen Adhipatie Tjokro Negoro, oud-regent van Poerworedjo (b.l.) Hadjie Mahamad Moesa, hoofdpanghoeloe van Limbangan (b.l.)

1864 Radhen Toemenggong Danoe Koesoemoe, regent van Malang (g.1.) ${ }^{1}$ Radhen Adhipatie Soerio Koesoemoe Adi Noto, te Soemedang (g.l.)

1865 Raden Saleh, kunstschilder te Batavia (g.l.)

Radhen Adipati Aria Koesoema Diningrat, regent van Galoe (g.l.)

1866 Toemenggong Wira Adek Daha, regent van Soekapura (g.1.) Raden Saleh (e.1.) $)^{2}$

(b.l. buitengewoon lid g.l. gewoon lid e.l. erelid)

In de notulen van 1861-1867 komen alleen en passant twee andere Indonesische leden ter sprake: het buitengewoon lid R.A. Ario Donoe Diningrat uit Magelang en het erelid Pangeran Adipati Mangkoe Negoro uit Soerakarta. Van zes Indonesische leden in 1861 was dat aantal in 1867 opgelopen tot twaalf op een totaal van 305 leden. De Indonesische leden waren tegenover Nederlandse ambtenaren in het genootschap in een overduidelijke minder-

1 Zijn lidmaatschap was van korte duur. Hij zegde op 27-12-1866 weer op. Notulen 4:276.

$2 \quad$ Notulen 1:131, 2:99, 101, 3:127, 4:135, 216. 
heidspositie. In de periferie waren zij nog minder bij de zaken betrokken dan de Bataviase leden dat waren. Hun stem werd nauwelijks gehoord. Raden Saleh was door zijn drieëntwintig jaren durend verblijf in Nederland en zijn bevoorrechte behandeling aldaar in een bijzondere positie op het moment van terugkomst (Spaanjaard 1998:15-21). Vandaar dat naar hem geluisterd werd. De inschakeling van Ida Ketoet Anom uit Boeleleng, door Van Kinsbergen 'meegebragt' uit Bali (1866) in een gezelschap van nog vier andere Balinezen, was een poging om 'Balische geleerdheid' in te schakelen bij het verklaren van de inhoud van de handschriften van dat eiland. Het is een van de weinige voorbeelden van actieve betrokkenheid van inheemsen bij de zaken van het genootschap. Van Ketoet Anoms kennis van het Kawi profiteerde het genootschap maar met mate. De zending liep op een teleurstelling uit voor wat het Kawi betreft, al werd van hem wel gebruik gemaakt voor het catalogiseren van de handschriften en van de Balinese etnologische voorwerpen. De vijf Balinezen bij Van Kinsbergen in huis zullen een schilderachtig tafereel hebben opgeleverd (Notulen 4:103, 149-50). Van Kinsbergen maakte er een prachtig portret van. Het genootschap stond in dit geval open voor de deskundigheid van Indonesiërs.

De grootste uitdaging voor het bestuur en het genootschap als geheel was om verder te professionaliseren, het beheer van het museum te verbeteren en de collecties beter open te leggen. Dat zou ook in het overblijvende deel van de negentiende eeuw vooral door Nederlanders worden aangepakt.

\section{Een nieuw reglement}

Op 16 november 1861 keurde de algemene vergadering van het genootschap een nieuw reglement goed, dat op 1 januari 1862 van kracht werd. Het verving de oude wetten van 1823, die onbruikbaar waren geworden. Eerdere pogingen om nieuwe wetten vast te stellen, waren vooral uitgegaan van oudsecretaris Bleeker. Zijn ideeën over een koloniale academie van wetenschappen vonden geen weerklank in het genootschapsbestuur. Zijn voorstellen om het ledental drastisch te beperken en de contributie aanzienlijk te verhogen leden schipbreuk op de reacties van de leden zelf. Daarna was de zaak blijven rusten, al bleef het duidelijk dat het genootschap niet langer kon steunen op het reglement dat door Van der Vinne onder het beschermheerschap van Van der Capellen was vastgesteld.

Het meest opvallende aan het nieuwe reglement is de terugkeer in de tekst van de rol van het gouvernement en daarmee de erkenning dat de overheid een belangrijke plaats innam. In 1823 was die rol helemaal uit de tekst verdwenen, wat ten opzichte van de eerdere formuleringen in wetten en grondwetten een grote verandering was geweest. Het reglement van 1861 
noemde zelfs in de aanhef meteen het gouvernement. 'Onder de bescherming der regering van Nederlandsch-Indië stelt het genootschap zich ten doel bevordering van kennis en wetenschap'. De naam van het genootschap en de zinspreuk, 'Tot nut van 't Algemeen', bleven gehandhaafd, maar in het eerste artikel werden de kunsten niet genoemd. Door nadrukkelijk kennis en wetenschap te omschrijven als het werkterrein van het genootschap werd bevestigd dat de kunsten vooral in de langzamerhand verouderde betekenis van 'kennis en kunde' dienden te worden opgevat. Een genootschap dat zich richtte op schone kunsten had nooit in de bedoeling gelegen. Het bestuur van 1861 legde daarmee het sinds lang gevoerde beleid in het reglement vast.

Nog drie andere punten waren anders dan in 1823. De 'voortplanting en uitbreiding van beschaving en verlichting in de Nederlandsch-Oost-Indische bezittingen' werd geschrapt. De tekst van 1861 was veel kaler en zakelijker en voor de beschavende arbeid hoefde geen plaats te worden ingeruimd. Door kennis en wetenschap te bevorderen werkte men al 'beschavend en verlichtend'. Uit het werkterrein van het genootschap viel nu ook de natuurlijke historie zo goed als weg, een wetenschapsterrein dat immers al jaren eerder door de Natuurkundige Vereeniging was overgenomen. Alleen de mineralogische verzameling bestond nog. Verder werd niet meer gesproken over het bevorderen van de landbouw, de economie en de nijverheid. Ook die terreinen hadden in de Nederlandsch-Indische Maatschappij van Nijverheid hun eigen organisatievorm gevonden. Het genootschap wilde een moderne organisatie met wetenschappelijke doelstellingen zijn en schudde een stuk van het verleden definitief van zich af. Het werkterrein werd in vier punten omschreven, zaken die in hoofdzaak gebleven waren:

a. de geschiedenis, talen, oudheden, zeden, gewoonten en instellingen der Indische en andere Oostersche volkeren;

b. de aardrijkskundige gesteldheid van den Indischen Archipel;

c. de geschiedenis der Nederlanders in Indië; en

d. de statistiek van Nederlandsch-Indië, in verband met de staathuishoudkunde (TBG 12:193).

De volken, talen, zeden, oudheden en geschiedenis van de Indische gewesten hadden al in 1778 de belangstelling van het genootschap gehad. In dat opzicht is het begrijpelijk dat het bestuur in 1861 de band met de oprichters wilde bewaren door de naam van het genootschap ongewijzigd te laten. Er was geen sprake van een radicale breuk met het verleden. Het vereenvoudigde reglement, dat in zeventien artikelen kon vastleggen waar in 1823 nog vijfenveertig artikelen voor nodig waren, vroeg wel om nadere bepalingen van een aantal huishoudelijke zaken. Daarom kreeg het bestuur mandaat om een reglement van orde vast te stellen, wat al op 4 januari 1862 gebeurde (TBG 12:199-206).

Wat de werkzaamheden betreft werd het uitbrengen van verslagen over het werkterrein van het genootschap, op verzoek van de regering of anderen, 
voorop gesteld. Daarna volgde het uitgeven van een of meer tijdschriften en bundels met verhandelingen. Prijsvragen uitschrijven werd als mogelijkheid nog steeds vermeld. Verder zou het genootschap 'zooveel mogelijk zijne verzameling van natuur- en kunstvoortbrengselen uitbreiden, vooral in verband met de onderwerpen, aan welke het zijn bijzondere zorg wijdt' (TBG 12:194). Die onderwerpen, punt a tot en met $d$, waren al in het eerste artikel opgesomd. Tenslotte wilde het genootschap met zusterinstellingen die elders gevestigd waren, tot uitwisseling van uitgaven blijven komen.

De categorieën leden bleven onveranderd: gewone, buitengewone, corresponderende en ereleden. Belangstelling in kunsten en wetenschappen vormde de enige voorwaarde voor het lidmaatschap. 'Braafheid, verdiensten en kundigheden', die in 1823 nog voorop hadden gestaan voor aspirant-leden, verdwenen. Het lidmaatschapsgeld bleef onveranderd veertig gulden per jaar bedragen, alleen te betalen door de gewone leden in Nederland-Indië. Het bestuur van elf leden telde een voorzitter, ondervoorzitter, secretaris, bibliothecaris, penningmeester, een of meer directeuren van de verzamelingen en een directeur van de gebouwen. Het secretariaat, het bibliothecarisambt en het penningmeesterschap waren bezoldigd, elk met honderd gulden per maand. Het bestuur was oppermachtig. Het besliste over de benoeming van nieuwe leden, waartoe eertijds de algemene ledenvergadering gemachtigd was. Die vergaderingen beperkten zich nu tot het doen van mededelingen en voorstellen (maar niet over nieuwe leden), het bespreken van wetenschappelijke onderwerpen, het houden van lezingen en het uitreiken van beloningen voor bekroonde prijsvragen (TBG 12:196-7). Dat laatste kwam echter in de praktijk niet meer voor. De laatste prijsvraag was in 1852 uitgeschreven. De gewone leden waren, als zij naar de algemene vergaderingen zouden komen, eigenlijk tot luisteraars geworden. Het is veelzeggend dat op de algemene vergadering van 16 november 1861, waar dit alles werd besloten, slechts vier gewone leden aanwezig waren, terwijl de tien zittende bestuursleden er wel allen waren. Het zittende bestuur had zichzelf in een nog prominenter positie geplaatst dan voorgaande besturen al hadden gedaan. In het reglement was dat bovendien vastgelegd.

In het nieuwe reglement werd over een beschermheer niet gesproken, maar op de algemene vergadering van 16 november werd besloten om de nieuwe gouverneur-generaal, L.A.J.W baron Sloet van de Beele, het beschermheerschap aan te bieden, zoals ook met zijn voorgangers was gebeurd. Daarbij werd in de overwegingen gememoreerd dat de gouverneur-generaal en de leden van de Raad van Indië eertijds de directie van het genootschap uitmaakten, maar dat 'ten gevolge van veranderde omstandigheden, de directie niet meer in handen was van de regering'. ${ }^{3}$ Sloet van de Beele zou in december al instemmen. 
De man die zich over het nieuwe reglement had gebogen, was de jurist Timon Henricus der Kinderen. Hij was in 1823 in Den Haag geboren en was in 1847 in Leiden in de rechten gepromoveerd. Na een korte periode als advocaat in Den Haag werkzaam te zijn geweest, vertrok hij naar Batavia, waar hij in september 1849 als eerste commies bij het parket van de procureurgeneraal kwam te werken. Na een korte tijd in Soerabaija als griffier bij de Raad van Justitie te heben gewerkt, werd hij in 1854 benoemd tot griffier en in 1861 tot raadsheer bij het Hooggerechtshof in Batavia. Zijn carrière zou hij vervolgen als procureur-generaal (1866), directeur van het nieuw opgerichte Departement van Justitie (1869), president van het Hooggerechtshof (1871) om te eindigen als lid van de Raad van Indië (1872-1887). In dat laatste jaar vroeg hij om gezondheidsredenen verlof aan. Der Kinderen was een hardwerkend en bekwaam jurist, die aan de wieg stond van veel wetgevende maatregelen. In 1863 was hij benoemd tot regeringscommissaris tot het ontwerpen van een regeling van het rechtswezen in de buitenbezittingen. Daaraan werkte hij vele jaren naast zijn zojuist opgesomde functies. Als gevolg daarvan kwam tussen 1875 (West-Sumatra) en 1892 (Billiton) een hele serie, aan de verschillende eilanden en streken aangepaste regelingen tot stand (L.W.C. van den Berg 1899).

Der Kinderen was spoedig na zijn overkomst lid geworden van het genootschap (1850), maar in het bestuur werd pas een plaats voor hem gevonden in juli 1860, toen Bleeker aftrad als secretaris. Netscher nam toen het secretariaat over en Der Kinderen werd gewoon bestuurslid. Zijn eerste taak in het bestuur kreeg hij in februari 1861, toen hem werd verzocht een nieuwe 'wet' voor het genootschap te ontwerpen. ${ }^{4}$ Dat deed hij snel en vaardig, zodat nog met ingang van 1862 het nieuwe reglement in werking kon treden. Het voldeed de hele lange bestuursperiode van Der Kinderen en hoefde pas in 1888 vervangen te worden. Na Netschers vertrek naar Riouw nam Der Kinderen in mei 1861 het secretariaat over, terwijl hij ook voorlopig de redactie van de Verhandelingen en het directeurschap van het museum op zich nam. In 1864 werd Der Kinderen tot vice-voorzitter gekozen, toen Van der Wijck naar Nederland vertrok. Na de dood van Alexander Loudon werd hij voorzitter, van december 1868 tot juli 1887, bijna negentien jaar. Hij was door zijn lange ambtsperiode in Batavia, zijn langdurig lidmaatschap van de Raad van Indië en zijn juridische vakkennis een autoriteit in de hoofdplaats en daarbij paste het voorzitterschap van het genootschap. Met zevenentwintig jaar in het bestuur domineert zijn persoonlijkheid een kwart eeuw genootschapsgeschiedenis. Het honderdjarig bestaan (1878) viel midden in de periode van zijn voorzitterschap en werd dan ook door hem geregisseerd. 
Der Kinderen kwam niet terug naar Indië. In Nederland zette hij zich onder meer in voor de armenzorg. Ook was hij bijna negen jaar voorzitter van het KITLV en bestuurslid van het Indisch Genootschap. In 1898 overleed hij, het einde van een welbesteed leven (L.W.C. van den Berg 1899:206-7).

\section{Beheer en behoud van oudheden op Java}

De aandacht voor de oudheidkundige resten op Java had al onder gouverneur-generaal Van der Capellen geleid tot het instellen van een oudheidkundige commissie (1822), die overigens tot niets kwam. In de jaren 1830 werd door de directeur van het Rijksmuseum van Oudheden in Leiden, de hoogleraar archeologie Caspar Reuvens (1793-1835), gewezen op de noodzaak van maatregelen en daarna door zijn opvolger bij het museum, Conrad Leemans (1809-1893), opnieuw. Weliswaar had het gouvernement vanaf 1840 meer structurele maatregelen genomen, die neerkwamen op een uitvoerverbod van oudheidkundige voorwerpen, maar de naleving daarvan liet zeer veel te wensen over. De belangstelling werd binnen het genootschap vooral gedragen door eenlingen, zoals Van Hoëvell, die op zijn reizen tempelresten bezocht en ervoor zorgde dat verspreide stenen en beelden naar Batavia werden vervoerd. In de periode van de bouw van het museum ontwikkelde de overheid steeds duidelijker een door maatregelen onderbouwd en met subsidies gedoteerd beleid voor het beheer en behoud van de oudheidkundige resten. Terwijl het nog tot 1901 duurde eer er een apart overheidsorgaan zou komen dat deze zorg op zich nam, de nieuwe Oudheidkundige Commissie, werd het genootschap meer en meer de voorloper van deze instelling. Het gaf gevraagd en ongevraagd advies aan het gouvernement in Batavia en nam initiatieven die van visie en ambities getuigden. Met de oudheidkundige missie van Brumund en het werk voor een oudheidkundige kaart, de samenstelling van een collectie inscripties en de opdracht voor het documenteren van de oudheden aan de fotograaf Van Kinsbergen kreeg de zorg voor oudheden op Java naast de zorg voor de eigen oudheidkundige afdeling in het museum een duidelijker gezicht. Zo vonden het genootschap en de overheid ieder hun plaats op dit verwaarloosde terrein.

$\mathrm{Nu}$ was vóór 1860 ook wel iets gedaan, maar het had allemaal veel tijd gekost. Een brief van de minister van koloniën van 25 november 1853 over het onderwerp had in april 1854 geleid tot het verzoek van het gouvernement aan het genootschap om daar 'haar gevoelen' over uit te brengen. Daarna had dat verzoek precies drie jaar onbeantwoord gelegen. ${ }^{5}$ Toen het in 1857 eindelijk tot 
iets kwam, ging het advies van het genootschap de regering te ver. Het stelde namelijk voor te bepalen, dat alle oudheidkundige voorwerpen die zich op publiek terrein bevonden, voortaan als openbaar eigendom zouden worden beschouwd en dat vernieling, beschadiging of wegvoering ervan strafbaar zou worden. Verder zouden oudheidkundige voorwerpen in particulier bezit niet zonder meer van Java mogen worden meegenomen. Eerst zou daarvoor toestemming van de gouverneur-generaal moeten worden verkregen. Uitvoer naar Nederland zou wel gemakkelijker worden, maar dan wilde het genootschap vooraf in de gelegenheid zijn gesteld om met de eigenaars te overleggen over overname (TBG 12:184-6). Het is jammer voor het genootschap, dat deze verregaande voorstellen niet door het gouvernement werden overgenomen. Er had toen al een duidelijke rol voor de initiatiefnemers kunnen zijn weggelegd: een oudheidkundige inspectiedienst. Wel profiteerde het genootschap sinds 1855 van een maatregel, waardoor het gouvernement beschikte over opgegraven munten en andere waardevolle voorwerpen. Daardoor groeide de collectie van munten en kleinere voorwerpen van edelmetalen, die tegen betaling van de overheid werden overgenomen. In 1861 vroeg het genootschap in aanvulling hierop aan de hoofden van het gewestelijk bestuur dat ook vondsten van 'voorwerpen in steen en onedele metalen' aan het genootschap zouden worden gemeld. Het had de indruk gekregen dat de regeringsmaatregel van 1855 te strikt werd uitgelegd (TBG 12:186-7).

Het voorzitterschap van F.V.A. ridder De Stuers, die in 1857 de hamer overnam van het weinig toeschietelijke lid van de Raad van Indië Visscher, werkte voor de oudheden gunstig. Juist onder Visscher was het verzoek om advies over de Javaanse oudheden drie jaar blijven liggen. De Stuers, zelf geïnteresseerd in het beheer van cultuurgoed, in het bijzonder in het behoud van de oudheden op Java, had op een reis over het eiland (1857) kunnen zien dat er veel moest worden gedaan. Her en der waren hem door bestuursambtenaren beloften gedaan dat er beter op de zaken zou worden gepast (TBG 12:186-7). Tenslotte had het genootschap in 1858 een oproep geplaatst om opgaven te ontvangen van overblijfselen 'uit Java's voortijd', te onderscheiden in 'ruïnen van groote en kleine tempels, ruïnen van andere gebouwen, beschreven steenen, zorgvuldig bewerkte steenen beelden en ruw bewerkte steenen beelden'. Een soortgelijke oproep aan de hoofden van gewestelijk bestuur ten behoeve van een samen te stellen oudheidkundige kaart van Java, ging eind 1860 uit (TBG 12:187-8).

Een hele reeks gebeurtenissen op het terrein van het oudheidkundig onderzoek kwam voort uit beslissingen die werden uitgelokt door een nota van de al genoemde directeur van het Rijksmuseum van Oudheden in Leiden, Leemans, en een tweede van de conservator bij hetzelfde museum, L.J.F. Janssen. Janssen had op 1 augustus 1861 in Leiden de laatste hand gelegd aan een nota getiteld 'Iets over de bevordering van de kennis der Oudheden, en 
in het algemeen van den vroegeren beschavingstoestand onzer Oost-Indische bezittingen'. Bij het samenstellen van zijn nota had hij gebruik gemaakt van gegevens, die hij van de net in patria teruggekeerde genootschapssecretaris Bleeker had ontvangen. Bleeker had Janssen onder meer onderhouden over de noodzaak om te komen tot een Indisch museum voor de verschillende organisaties in Batavia. ${ }^{6}$ Op 6 augustus 1861 had Leemans vanuit zijn zomerverblijf te Zaltbommel een tweede nota aan die van zijn conservator toegevoegd, bedoeld voor de nieuw benoemde gouverneur-generaal Sloet van de Beele, die later die maand naar Batavia zou vertrekken. Deed Janssen verslag van zijn gespek met Bleeker, Leemans had uitgebreid met Friederich gesproken, ook al met oog op de speciale opdracht die deze bij terugkeer naar Indië zou krijgen. Janssen en Leemans drongen aan op drie maatregelen:

1 het samenstellen van een oudheidkundige statistiek, in de zin van een beredeneerd overzicht gebaseerd op een nauwkeurige opname,

2 het actief verzamelen in Indië ten behoeve van het Museum van Oudheden in Leiden van zowel archeologische als etnologische voorwerpen, en

3 het maken van tekeningen van monumenten en het afdrukken van inscripties.

Leemans had geen hoge pet op van musea onder de tropenhemel: 'Van Museums op Java stel ik mij niet veel, op zijn meest slechts eene tijdelijke werking, voor. [...] Een goed Museum van Natuurlijke Historie schijnt daar, in dat klimaat, en de onveranderlijke omstandigheden, onmogelijk te zijn'. Oudheden waren minder problematisch, maar waren in Batavia slechts in beperkte kring van nut, aldus de Leidse directeur. Verder werkte de voortdurende wisseling van personeel 'zeer nadeelig op de onafgebroken, naauwkeurige zorg voor een Museum'. Daar voegde Leemans het voorbeeld bij van een in het museum van het genootschap zoekgeraakte, bronzen beker met Kawi-inscriptie.

De nota's werden op 8 januari 1862 door het gouvernement aan het genootschap aangeboden met het verzoek om advies. ${ }^{7}$ Uiteraard stonden in deze nota's de belangen van het onderzoek in Nederland en van de collecties in Leiden voorop. Leemans had in zijn nota hoog opgegeven van het vertrouwen dat hij stelde in Sloet van de Beele, de 'zoo verlichten, kundigen, scherpzinnigen man'. Even vanzelfsprekend is het dat het genootschap in zijn advies de belangen van het onderzoek op Java en van de collecties in Batavia voorop zou plaatsen. $\mathrm{Nu}$ ging het erom dat te doen op een overtuigende manier, opdat de belangen van Batavia niet ondergeschikt zouden worden gemaakt aan die van Leiden.

6 De nota's van Janssen en Leemans zijn te vinden in het ANRI Archief Algemene Secretarie bij het gouvernementsbesluit 24-5-1862 no 2.

7 TBG 12:514, vergadering 5-4-1862. 
Tussen januari en april 1862 werd binnen het bestuur uitgebreid overlegd over het advies, dat op 22 april aan Sloet van de Beele kon uitgaan. Het bestuur wees de bestaande, oudere gegevens, die zouden moeten dienen voor een oudheidkundig-statistisch overzicht, als onbruikbaar van de hand. Die gegevens waren grotendeels binnengekomen na een oproep van het gouvernement aan de plaatselijke autoriteiten in 1840. Ook de gegevens waarover het genootschap zelf beschikte naar aanleiding van een soortgelijke oproep uit 1860 waren onvoldoende. Het noemde de sinds 1840 bereikte resultaten ronduit 'zeer onbeduidend' (TBG 12:518). Dit stond in schril contrast tot de uitmuntende opgave, waarover Leemans zei te beschikken. Als enig mogelijke oplossing om te komen tot goede gegevens voor een oudheidkundig overzicht, zag het genootschap, dat aan een onderlegd oudheidkundige de opdracht zou worden gegeven om alles persoonlijk te gaan zien, beschrijven, uitleggen en toelichten. En dat zou niet moeten resulteren in 'eene dorre statistiek, maar eene in alle bijzonderheden afdalende beschrijving'. Na het formuleren van deze 'terms of reference' kon het bestuur met een bijbehorende persoon voor de dag komen: de predikant J.F.G. Brumund. Hij was de juiste man voor zo'n opdracht. Hij zou ontslag moeten krijgen als predikant en het laatste jaar voor zijn pensionering kunnen gebruiken voor een lange reis langs Java's monumenten en opgravingen. Het kader van Brumunds opdracht werd al in het advies aan het gouvernement opgenomen.

Een tweede aspect, het maken van afbeeldingen van monumenten en kopieën van inscripties, zou het beste via het nieuwe middel van de fotografie kunnen gebeuren. De voorstellen van Leemans en Janssen: afgaan op de tekeningen van Wilsen en kurkmodellen van de tempels laten maken door iemand uit Zutphen, werden van de hand gewezen. Leemans zag niets in de fotografie en was in dit opzicht behoudend, al was eigenbelang daaraan niet vreemd. Zijn Boroboedoer-studie met lithografieën moest nog verschijnen. Hij beschouwde het hele fotografie-project als weggegooid geld. Het genootschap stelde echter voor dat er in Europa een drietal 'uitstekende, wetenschappelijke photographisten (TBG 12:524)' zou worden opgeleid. Deze moderne methode van documenteren was veruit de beste. $\mathrm{Zij}$ zouden dan op aanwijzing van Brumund foto's moeten maken.

De derde aanbeveling van Leemans en Janssen, het verzamelen van archeologische en etnologische voorwerpen vooral voor het museum in Leiden, was door de Leidenaren aangekleed met een tweetal, al gesignaleerde argumenten: de verzameling in Batavia was voor een te beperkte kring voor wetenschappelijk onderzoek toegankelijk en de voortdurende wisseling in het bestuur werkte nadelig op de zorg voor het museum. Daardoor zouden voorwerpen wegraken (TBG 12:527). Het bestuur in Batavia stelde zich listig op door de argumenten te ondergraven, maar eerst toonde het zijn goede wil. Het had inderdaad als gevolg van de regeringsmaatregel van 1855 nogal 
wat opgegraven voorwerpen kunnen aankopen. Het had echter lang niet alles overgenomen. De niet overgenomen voorwerpen hadden door Leiden kunnen worden aangekocht. Het genootschap had wel bij die aankoop willen bemiddelen. Verder wilde het meewerken aan de vervaardiging van afgietsels van inscripties uit het museum in Batavia ten behoeve van Leiden. Ook zou het bestuur de leden van het genootschap kunnen vragen of zij instemden met het afstaan van doubletten aan de Leidse broeders. 'Maar op den voorgrond staat en moet blijven staan het museum van het genootschap' (TBG 12:526-7).

De aanbeveling van Leemans werd vervolgens door het bestuur uitgekleed: het bestuur kon moeilijk van eenzijdigheid bij het verzamelen worden beschuldigd. Eén enkel bezoek aan het museum zou volstaan om dat te zien. Bovendien was de voortdurende wisseling van bestuursleden juist een garantie dat niet één specialisme de overhand zou krijgen, dat niet 'eene afkeurenswaardige, éénzijdige rigting, lang dure'. Voorwaar een vondst, het nadeel volgens Leemans werd in een voordeel omgekeerd (TBG 12:527). Tenslotte werd de aantijging van de vermiste Kawi-beker met een persoonlijk argument gepareerd door de aangesproken persoon, de gouverneur-generaal, tot getuige te roepen.

En wat de zorg voor de verzameling betreft, die is zoo goed als hare ellendige, bekrompene woning slechts toelaat en de heer Leemans zou ongetwijfeld leed gevoelen over zijne aantijging van het verdwijnen van de zoogenoemden kawibeker, wanneer hij eens in de gelegenheid ware de verzameling te bezoeken en hem dan, onder een schat van merkwaardige oudheidkundige voorwerpen, mede die zoo zeldzame beker werd aangewezen, gelijk hij ook aan Uwe Excellentie, toen $\mathrm{Zij}$ het museum met een bezoek vereerde, werd vertoond (TBG 12:527-8).

Leemans en Janssen kregen en passant nog ingewreven dat geen enkele wetenschapper Batavia verliet zonder het museum van het genootschap te bezoeken. De gouverneur-generaal werd herinnerd aan de problematiek van de behuizing, maar vast stond dat het genootschap trots mocht zijn op zijn verzameling. Heel Nederlands-Indië had er recht op dat het museum de bewaarplaats zou blijven van Indië's oudheden: 'zij moet de hulpbron zijn en blijven van menigen jeugdigen Indischen geleerde' en 'een der eerste sieraden van Batavia' (TBG 12:528).

De argumentatie en de aanbevelingen van Leemans en Janssen waren - naar het gevoel van het bestuur - misschien op overtuigende wijze ondergraven, erg sterk komen de tegenargumenten niet over. Wie moest men zich voorstellen bij 'menigen jeugdigen Indischen geleerde'? Het gymnasium Koning Willem III had nog maar net zijn poorten geopend. En de omkering van Leemans' argument - veel afwisseling in het bestuur behoedde voor eenzijdigheid - was ook niet sterk. Toch is in de lange brief aan de gouverneur- 
generaal het nodige retorische vernuft gemengd met wat minzaamheid. Waarschijnlijk had secretaris Der Kinderen de hand in de formulering van het advies. Het museum in Leiden had nu de tweede keuze bij beschikbaar gekomen, opgegraven voorwerpen. Het kon doubletten en afgietsels van inscripties krijgen en etnologische voorwerpen konden voor Leiden verzameld worden 'zonder benadeeling van de belangen des genootschaps reeds zoo schoone, ethnographische verzameling' (TBG 12:529-30).

Het lange beleidsstuk reikte het gouvernement in antwoord op de drie gevraagde maatregelen van Leemans en Janssen een serie concrete adviezen aan. De belangrijkste waren de volgende.

1 Brumund zou de opdracht moeten krijgen om een beschrijving te maken van de hindoe-oudheden op Java. Hij zou het genootschap opgaven moeten doen voor het samenstellen van een oudheidkundige kaart, moeten aangeven welke beelden en gedenkstenen naar Batavia konden worden overgebracht en welke oudheden en inscripties moesten worden afgebeeld. De predikant zou daarvoor ontslag moeten nemen en met behoud van alle faciliteiten op reis kunnen gaan, tijdens welke reis hij alle hulp van de plaatselijke autoriteiten zou moeten krijgen.

2 Drie fotografen zouden onder toezicht van het genootschap op Brumunds aanwijzingen afbeeldingen moeten maken. Zowel Brumunds beschrijving als de foto's zouden ter beschikking komen van het genootschap.

3 Door Brumund aangewezen voorwerpen zouden door de hoofden van gewestelijk bestuur naar Batavia worden gestuurd, aan het adres van het genootschap. Die hoofden zouden ook opgeroepen moeten worden om etnologische voorwerpen te verzamelen. Het genootschap zou dan aan de regering opgeven welke van de voorwerpen het wenste te behouden en welke naar Leiden konden worden doorgestuurd.

4 Het genootschap tekende aan bereid te zijn aankopen te doen voor Leiden, afgietsels te maken en doubletten af te staan.

Sloet van de Beele noteerde op het origineel van de brief van het genootschap van 22 april 1862: 'Een goed rapport en voorstel dat ik reeds aan zoude nemen zoo het regelen der financien mij duidelijk was. Daarover wensch ik met spoed den Directeur te hooren, terwijl de alg. Secretarie mij het noodige licht kunne geven. ${ }^{8}$ Het gouvernement had daarna niet veel tijd nodig om de zaak af te handelen. Op 5 mei 1862 ging al een brief aan Brumund uit om diens ontslagaanvrage als predikant uit te lokken, op 24 mei van hetzelfde jaar gevolgd door een gouvernementsbesluit, dat de aanbevelingen van het genootschap grotendeels volgde. Alleen het uitbreiden van de opdracht

8 In het handschrift van de gouverneur-generaal op de brief van 22-4-1862. ANRI Archief Algemene Secretarie bij gouvernementsbesluit 24-5-1862 no 2. 
aan Brumund met een taak voor drie fotografen werd in beraad gehouden. Daarover werd eerst advies gevraagd aan de adviseur voor technische zaken van het ministerie van koloniën, T.J. Stieltjes, die in Indië verbleef voor spoorwegaangelegenheden en die over de fotograaf Elias beschikte. ${ }^{9}$

De positie van het genootschap was versterkt. Het museum in Leiden moest voorlopig afwachten met welke voorstellen het genootschap zou komen voor het doorzenden van oudheidkundige en etnologische voorwerpen. Niet alleen was Brumund een jaar lang voor de opdracht beschikbaar, het genootschap zou zowel over zijn beschrijving als over de statistische gegevens voor de oudheidkundige kaart komen te beschikken. Verder mocht verwacht worden dat er nogal wat voorwerpen naar Batavia zouden verhuizen. Anders dan de reizen van Van Hoëvell in de jaren 1840, die kerkelijke reizen waren, die hij voor een deel gebruikte voor het uitleven van zijn oudheidkundige belangstelling, was zijn ambtgenoot Brumund nu geheel voor het oudheidkundig onderzoek vrijgemaakt. Na Friederich had het genootschap zo voor het eerst weer iemand die zich voltijds aan onderzoek kon wijden. Op voorstel van de directeur van financiën kreeg hij daarvoor zijn tractement van $f$ 500, plus een verhoging van $f 450$ en een toelage voor het huishouden van $f$ 160. Tezamen $f 1.110$ per maand. ${ }^{10}$

Jan Frederik Gerrit Brumund was in 1814 in Amsterdam geboren. Hij studeerde theologie in Utrecht en werd in 1840 tot predikant voor Nederlands-Indië aangesteld. Zijn eerste standplaats was Soerakarta (1841), zijn laatste standplaats vóór zijn terugkeer naar Batavia in 1854, was Ambon (Nieuwenhuis 1978:130-2). Hij was naast predikant ook schrijver. Een reisimpressie van Bantam verscheen al in 1840 in het Tijdschrift voor Neêrland's Indië, gevolgd door stukken over de Aroe-eilanden en het Aroes. Hij had voor hij naar Soerakarta ging zeker Van Hoëvell in Batavia ontmoet, met wie hij zijn belangstelling voor land, volk en oudheden deelde. In twee bundels Indiana over de archeologische resten op Java (1853-54) had de predikant zich laten kennen als een goed oudheidkundige. Krom is in zijn Inleiding tot de HindoeJavaansche Kunst (1923) zeer positief over Brumund als oudheidkundige (Krom 1923, I:14-7). Brumund was, mede op grond van zijn publicaties na zijn terugkomst te Batavia op 24 april 1855 tot bestuurslid benoemd, in dezelfde vergadering als Netscher, Friederich en De Stuers. ${ }^{11}$ In februari 1857 verzocht hij ontslag als bestuurslid, in verband met een reis over Java, wegens een

9 Gouvernementsbesluit 24-5-1862 no 2 in TBG 12 (1862):552-7. Origineel in Archief Algemene Secretarie.

10 Het voorstel van de directeur van financiën 14-5-1862 zit bij het bedoelde gouvernementsbesluit.

11 ANRI KBG Dir 0209, vergadering 11-4-1855, punt 3; Dir 0210, vergadering 24-4-1855, punt 4; TBG 4:199. 
opdracht van het gouvernement om een beschrijving van de Boroboedoer te leveren, bedoeld ter ondersteuning van de in Nederland te publiceren tekeningen van Wilsen en Schönberg Müller. Zijn grote beschrijving zou echter tot zijn teleurstelling niet de hoofdmoot van de monumentale BôrôBoedoer van Leemans (1873) vormen, al maakte de Leidse museumdirecteur van Brumunds gegevens wel gebruik. Toen Brumund in Nederland was (1858-1859), stond hij verschillende opstellen af aan Van Hoëvell voor diens tijdschrift. Vóór zijn vertrek had hij het genootschap van zijn Javaanse reis verslag gedaan, onder andere over Singosari, en zijn Boroboedoer-stuk aangeboden, als het gouvernement daar toestemming voor zou geven, hetgeen niet gebeurde. ${ }^{12}$ We treffen in het tijdschrift van het genootschap in de eerste jaargangen van hem alleen een verhaal aan over een Molukse reis, maar van hem niets over de Boroboedoer, Penataran of Singosari of andere Javaanse oudheden. Zijn stukken kwamen in de eigen bundels Indiana terecht en in Van Hoëvells tijdschrift in Nederland.

Eenmaal terug in Batavia werd Brumund op 4 mei 1861 herbenoemd tot bestuurslid. ${ }^{13}$ Hij woonde echter geen vergaderingen bij tot die van 5 april 1862, toen zijn nieuwe opdracht werd besproken. Zijn afwezigheid bij de bestuursvergaderingen van 1861 en de eerste maanden van 1862 is opvallend. Met de nieuwe regeringsopdracht, die nauw aan het genootschap was verbonden, was hij weer helemaal terug in het bestuur. Eind juni 1862 was hij op reis.

In augustus deed hij verslag van zijn bezoek aan K.F. Holle met wie hij in Garoet Kawi-handschriften had bekeken. In oktober had hij plannen om over te steken naar Bali, waarvoor zijn opdracht, die zich tot Java beperkte, enigszins moest worden aangepast. In januari 1863 stuurde hij vanuit Pasoeroean verschillende stukken over Bantam, Buitenzorg en de Preanger Regentschappen, naast bijdragen voor de oudheidkundige kaart. Ook stuurde hij een lijst van te fotograferen objecten en deed hij opgave van de voorwerpen die naar Batavia zouden kunnen worden vervoerd. Hij meldde dat hij bezoeken had afgelegd aan Cheribon, Tegal, Pekalongan, Semarang, Pati, Rembang, Soerabaija, Pasoeroean, Banjoewangi en Bali, Panaroekan, Besoeki en Probolinggo. In februari 1863 stuurde hij nog twee brieven met het vervolg van de beschrijving van de oudheden in de Preanger Regentschappen, Cheribon, Tegal, Semarang en Bagelen. Hij was in Oost-Java opgehouden door de west-moesson, maar gebruikte zijn tijd door aan de beschrijving te werken (Notulen 1:17, 37, 90, 98). Brumund had het eerste half jaar goed gebruikt en veel gezien. Het genootschap had alle reden om opgeto- 
gen te zijn en het koesterde de verwachting dat Brumund zijn reis binnen het hem gegeven jaar zou voltooien. Groot was de schok toen op 13 maart 1863 het telegram van de resident van Pasoeroean, H.A. van der Poel, het bestuur inlichtte over het overlijden van Brumund in Malang, ten gevolge van een verwaarloosde leverontsteking. ${ }^{14}$ Het verlies voor het genootschap en voor de oudheidkunde op dat moment was groot.

Het bestuur benoemde een commissie om de stukken van Brumund te onderzoeken. Tevens zou die commissie bezien of een aanbod van Hageman uit Soerabaija om Brumunds opdracht af te maken, serieus genomen moest worden. ${ }^{15}$ Hageman zou die opdracht niet krijgen. Een deel van Brumunds aantekeningen over Bali zou direct gepubliceerd worden in het tijdschrift van het genootschap, een ander deel over hetzelfde eiland zou door de commissie worden bewerkt, terwijl een begin zou worden gemaakt met het drukken van Brumunds grote beschrijving over de oudheden op Java. ${ }^{16}$ Het verscheen als 'Bijdragen tot de kennis van het Hindoeisme op Java' pas in 1868 in de Verhandelingen. ${ }^{17}$

Mocht Hageman, in Soerabaija woonachtig als ambteloos burger, de opdracht van Brumund niet afmaken omdat hij daarvoor te weinig gekwalificeerd was? Op die vraag geven de notulen geen antwoord. Wie wel gekwalificeerd leek om de opdracht af te maken, was de voormalige adjunctbibliothecaris en eertijds bestuurslid, Friederich. Hij was in 1863, niet lang na het overlijden van Brumund teruggekomen van zijn ziekteverlof en had zich gemeld bij het genootschap met het verzoek om inzage te krijgen in de aantekeningen in het genootschapsarchief over oudheden. Ook vroeg hij toestemming om de inscripties in het museum af te drukken (Notulen 1:223). Friederich had namelijk bij zijn terugkeer naar Indië een regeringsopdracht meegekregen om inscripties op Java, Sumatra en Bali te verzamelen. Die opdracht had hij in den brede met Leemans besproken. ${ }^{18}$ Friederich mocht uiteindelijk terugreizen in het gezelschap van vier, in het Rijksmuseum van Oudheden in Leiden getrainde militairen, die afgietsels en afdruksels hadden leren maken en die ook tekeningen en opmetingen konden leveren. Deze opdracht was serieus voorbereid en Friederich had maar liefst vier assistenten meegekregen, terwijl Brumund alleen op reis was gegaan. Het

14 Notulen 1:109. Twee telegrammen van resident H.A. van der Poel, 13 en 14 maart 1863 in ANRI KBG Dir 0273, vergadering 24-3-1863.

$15 \quad$ Notulen 1:182, vergdering 18-4-1863.

16 Notulen 2:114-5, vergadering 30-4-1864.

17 VBG 33 (1868). Of er door de commissie nog veel aan gedaan moest worden, blijkt niet. Maar kennelijk was het manuscript niet meteen publicabel. Het genootschap liet in de delen 31 en 32 (1864 en 1865-1866) andere opstellen voor gaan.

18 Zie daarover Leemans' nota voor Sloet van de Beele, 6-8-1861, in ANRI Archief Algemene Secretarie, gouvernementsbesluit 24-5-1862 $\mathrm{nr} 2$. 
genootschap mocht, gezien het verleden, verwachten dat de interesse bij de voormalige adjunct-bibliothecaris om zijn oude stoel weer te bezetten niet groot was. Het bood Friederich dan ook geen plaats als bestuurslid aan. Maar kwam het niet in het bestuur op om Friederichs opdracht te combineren met de werkzaamheden die Brumund niet had kunnen afronden? Mogelijk bedankte Friederich zelf voor de eer. Hij was nu zelfstandig onderzoeker, niet gekoppeld aan het genootschap, dat hem zolang klein had gehouden.

Overigens was het verzamelen van inscripties ten behoeve van een corpus inscriptionum door Friederich zelf ter sprake gebracht in zijn publikatie 'Over inscripties van Java en Sumatra, voor het eerst ontcijferd' (VBG 26). Toen het Delftse Instituut de suggestie opnieuw deed, nam het genootschap die in 1859 over. ${ }^{19}$ Het stelde het gouvernement voor aan de hoofden van gewestelijk bestuur opdracht te geven tot het verzamelen van kopieën van inscripties. Er ging in november 1859 een circulaire over uit, nadat het gouvernement had aangegeven dat Friederich de binnenkomende kopieën zou kunnen verzamelen. Daarop kwamen nog hetzelfde jaar 1859 de eerste reacties binnen. In 1863 was het genootschap niet langer verantwoordelijk voor de verzamelen, ontcijferen en eventueel publiceren van inscripties. Dat was nu Friederichs taak. Zijn collectie afdruksels en kopieën van inscripties kwam na zijn ontslag in 1869 bij het genootschap terecht en vormde daar een belangrijke studiecollectie. Er was dan wel een corpus, de publicatie ervan liet nog op zich wachten.

Een project dat door de dood van Brumund eveneens verzandde, was het samenstellen van een oudheidkundige kaart. In november 1861 werd de algemene vergadering nog optimistisch voorgehouden dat die kaart zou worden gemaakt door Netscher en Versteeg op basis van de opgaven die daarover uit de verschillende gewesten op Java zouden binnenkomen (TBG 12:187-8). Het belang van zo'n kaart voor verder onderzoek was evident. Met die kaart in de hand zou de verspreiding van het hindoeïsme over Java in één oogopslag kunnen worden gevisualiseerd, een misschien wat optimistische gedachte. Toen bleek dat de inzendingen uit de gewesten tegenvielen, dan wel onbetrouwbaar waren, werd het project geïncorporeerd in de opdracht aan Brumund. Die opdracht zou dan een beschrijving én een oudheidkundige kaart opleveren. Na de dood van Brumund werkte een commissie wel aan zijn nalatenschap, maar zij concentreerde zich op de aantekeningen over Bali en de beschrijving van de oudheden op Java. De 'antiquarische kaart' ging weer een tijd de kast in.

Een project dat wel afgerond werd en dat rechtstreeks voortkwam uit de

19 Het gouvernement vroeg het genootschap op 14-4-1859 om advies. Het genootschap vergaderde erover op 14-5-1859. Zie TBG 9:226. 
opdracht aan Brumund, was de nevenopdracht aan de fotograaf Isidore van Kinsbergen. In het gouvernementsbesluit over de opdracht aan Brumund was het door het Bataviaasch Genootschap voorgestelde aantrekken van drie fotografen aangehouden in afwachting van het advies van Stieltjes over het inzetten van de fotograaf Elias. De naam van Elias werd echter niet meer genoemd.

Van Kinsbergen was geboren in 1821 in Brugge. Hij had zich bekwaamd in de zang- en schilderkunst en was en in 1851 met een operagezelschap naar Batavia gekomen. Daar raakte als decoratieschilder en zanger hij verbonden aan de Bataviase schouwburg. Hij was zich in Batavia gaan interesseren voor de fotografie, waartoe hij in de leer was gegaan bij Antoine Lecouteux. Fotografie werd gezien als een kunstvorm, dus bleef Van Kinsbergen in zijn branche werkzaam. In februari 1862 was hij zo bedreven dat hij als fotograaf mee kon op een diplomatieke reis naar Siam in het gevolg van algemeen secretaris Alexander Loudon. Aansluitend maakte hij in juni-juli 1862 een reis mee met gouverneur-generaal Sloet van de Beele naar Midden- en Oost-Java en Bali. Daarvan terug bood de gouverneur-generaal enkele van de door Van Kinsbergen gemaakte 'photographische afbeeldingen' van de Boroboedoer en de Prambanan-tempels aan het genootschap aan. Die werden begeleid door een brief van de eerste gouvernementssecretaris van 13 september 1862, waarbij deze meedeelde dat aan Van Kinsbergen was gevraagd of hij bereid was om mee te werken aan het vastleggen van de oudheden en inscripties die Brumund aan het beschrijven was. Sloet van de Beele nam op dat moment het initiatief om het fotografisch deel van de missie van Brumund te realiseren, echter op een andere wijze dan het genootschap had voorgesteld. Van Kinsbergen had er, onder bepaalde voorwaarden, wel oren naar. Het genootschap zag er, gezien de hoge kwaliteit van de geschonken foto's, veel in en koppelde er het voorstel aan vast dat Van Kinsbergen een assistent naast zich zou krijgen die hij zou moeten opleiden in de kunst. ${ }^{20}$

Nadat de directeur van financiën bezwaren had geuit tegen de voorwaarden die Van Kinsbergen had gesteld en een commissie van het genootschap met de fotograaf had onderhandeld, kwam het tot een definitief voorstel en een gouvernementsbesluit. Uiteindelijk werd op 2 december 1862 een overeenkomst gesloten tussen Van Kinsbergen en voorzitter Gerrit Wassink, waarbij het genootschap namens de regering optrad. ${ }^{21}$ De fotograaf zou drie

20 Notulen 1:5-6, vergadering 20-9-1862. Over Van Kinsbergen de studie en catalogus van zijn foto's door Theuns-de Boer en Asser (2005)

21 Notulen 1:36 (vergadering 11-10-1862), 40 (vergadering 22-11-1862), 57 (vergadering 27-121862) met gouvernementsbesluit 2-12-1862. Op 23-1-1863 blijkt de overeenkomst gesloten te zijn (Notulen 1:72). Het genootschapsexemplaar van de overeenkomst, getekend door Van Kinsbergen en Wassink, bevindt zich in een mapje Kinsbergiana in ANRI KBG Mus 0029. 
jaar over zijn opdracht mogen doen. Hij kreeg een maandelijkse vergoeding van $f 800$ in het eerste jaar, oplopend tot $f 1.000$ in het derde jaar. Ook mocht hij gebruik maken van gouvernements- en regentspaarden en van particuliere postpaarden. Van de door het genootschap opgegeven oudheidkundige objecten moest hij opnamen maken en aan het eind van iedere maand van ieder goedgekeurd cliché zes afdrukken leveren. Een interessante bepaling was nog dat elk door het genootschap afgekeurd cliché de fotograaf een boete van $f 100$ zou kosten. De financiering kwam, net als bij Brumunds missie, van het gouvernement. Fotograferen was niet goedkoop, dus werd er rekening mee gehouden dat het in het voor de opdracht aangewezen begrotingshoofdstuk genoemde bedrag van $f 37.500$ niet voldoende zou zijn. Dan zou aanvulling gevonden worden bij de post 'onvoorzien' van hetzelfde hoofdstuk. Zo had het genootschap begin 1863 een oudheidkundige én een fotograaf in dienst. Gouvernement en genootschap zaten op één lijn en de verwachtingen waren hooggespannen. De dood van Brumund in maart 1863 was een zware tegenvaller, maar het hinderde de opdracht aan de fotograaf niet. Zijn vertrek was vastgesteld op april 1863. Hij zou Brumunds reis als het ware nadoen en zou bij de uitvoering van zijn opdracht op de vingers gekeken worden door een commissie van maar liefst vier bestuursleden: Der Kinderen, Van der Chijs, Levyssohn Norman en Stortenbeker. ${ }^{22}$ In juli 1863 kwamen de eerste (21) foto's binnen, 'uitstekende photographische afbeeldingen', gemaakt in de residentie Buitenzorg. ${ }^{23}$

Terwijl Van Kinsbergen op reis was, stelde de commissie voor hoe het zou moeten met de clichés en de afdrukken van de foto's die hij maakte. Zij stelde voor van de zes afdrukken die Van Kinsbergen van iedere opname zou leveren, de eerste voor de koning te bestemmen, en de andere voor het genootschap zelf, voor het museum van oudheden in Leiden, en de resterende voor de Société Asiatique (Parijs), de Royal Asiatic Society of Bengal (Calcutta) en de Royal Asiatic Society of Great Britain and Ireland (Londen). Het was de bedoeling de foto's uit te geven bij de beschrijving van Brumund. Ze stonden niet op zich zelf. De regering - bang dat Van Kinsbergen teveel foto's zou gaan maken, waardoor de kosten te hoog zouden uitkomen - werd gerustgesteld: alleen wat bij Brumunds beschrijving zou horen, zou worden gefotografeerd. ${ }^{24}$ De kwaliteit van de door de gouverneur-generaal geschonken foto's en van de eenentwintig opnames die als eerste onderdeel van de genootschapsopdracht binnenkwamen, deed het bestuur beseffen dat de regering met de keuze voor deze fotograaf een schot in de roos had gedaan.

\footnotetext{
22 Notulen 1:99 (vergadering 27-3-1863), 145-6 (algemene vergadering 27-3-1863) en 191 (vergadering 18-4-1863).

$23 \quad$ Notulen 1:226, vergadering 3-7-1863.

24 Notulen 1:231-2 (vergadering 1-8-1863) en 286 (vergadering 24-10-1863).
} 
Vandaar dat over de verspreiding naar vier belangrijke instellingen al in een vroeg stadium werd beslist. De naam van het genootschap zou daardoor verder gevestigd worden als een instelling op het gebied van oudheidkunde. Om de resultaten echter niet tot de kleine kring van specialisten te beperken, onderzocht het genootschap de mogelijkheid om via een lithografisch procédé een ruimere verspreiding te verzekeren. De driehonderd foto's uit de opdracht zouden in een oplage van zeshonderd exemplaren (in totaal 180.000 afdrukken) in Brussel kunnen worden vermenigvuldigd. ${ }^{25}$

Van Kinsbergen werkte langzamer dan het genootschap had gehoopt. Enerzijds was het fotografisch procédé bewerkelijk. Anderzijds stelde de fotograaf hoge eisen aan zich zelf. Bij de Boroboedoer stonden verschillende bomen in de weg, zodat een opname van de tempel als geheel, vanuit de hoek die Van Kinsbergen had gekozen, onuitvoerbaar was. Dan moesten die bomen maar gekapt worden. Ook daarmee bemoeide het genootschap zich. ${ }^{26}$ In juli 1864 te Diëng aangekomen verwonderde Van Kinsbergen zich over de tempels daar. Hij liet de aarde rond de gebouwen weggraven en ontdekte dat een aanzienlijk gedeelte ervan onder het grondoppervlak gelegen was. Dat leidde tot een compleet opgravingsproject, waarbij de fotograaf zich ontwikkelde tot archeoloog. Op 1 augustus lichtte hij daar het genootschap over in. Hij stuurde tekeningen mee en deed voorstellen voor de voortgang van het project. Van Kinsbergens lange brief is een zeer levendig verslag en geeft herhaaldelijke blijk van het grote enthousiasme van de fotograaf-archeoloog. ${ }^{27}$ Het gouvernement gaf op 2 september 1864 de resident van Bagelen, C. Castens, opdracht met zijn eerstaanwezend ingenieur naar Diëng te reizen om met Van Kinsbergen te overleggen over de verdere uitgraving van de ruïnes aldaar. Er werd direct geld gerserveerd voor het project. Het genootschap was door het doortastende optreden van de ondernemende Van Kinsbergen een eigen archeologische opgraving rijk. Het uitgebreide verslag dat de amateurarcheoloog op 30 september 1864 vanuit Wonosobo naar Batavia stuurde, begeleid door tweeënzestig opnames die hij aldaar gemaakt had, laat zien dat hij naast de camera ook de pen vaardig hanteerde. Levendig ('Stel u voor mijne heeren!'), alsof hij het woord voerde op een vergadering, beschreef hij de gebeurtenissen, die aanleiding hadden gegeven tot de uitgraving, vanaf het moment van zijn eerste kennismaking met het gebied. ${ }^{28}$ Dit verslag, dat gepubliceerd werd, maar ook de niet in de Notulen afgedrukte brieven die

\footnotetext{
25 Notulen 2:19, vergadering 9-1-1864.

26 Notulen 2:89, vergadering 2-4-1864.

27 In het genootschapsarchief over de jaren 1863-1867 bevinden zich interessante brieven en tekeningen van Van Kinsbergen, alsmede enkele foto's. Brief van 1-8-1864 in ANRI KBG Dir 0292, waarbij een viertal belangrijke schetsen van Diëng.

28 Notulen 2:261-9, vergadering 5-11-1864.
} 
zich in het genootschapsarchief bevinden, laten zien dat hij de kennis over Diëng sinds het bezoek van Brumund en diens aantekeningen erover, vooruit had gebracht. De beschrijving van het complex van tempels was sinds de uitgraving aanzienlijk bijgesteld en de onderlinge verhouding tussen de verschillende tempels veel duidelijker geworden. Men durfde nu van een tempelstad te spreken. In het volgende jaar, mei 1865, vond het genootschap dat een commissie van drie bestuursleden, Rochussen, Levyssohn Norman en Van den Berg, poolshoogte moest gaan nemen te Diëng, om het gouvernement beter te kunnen adviseren over het vervolg van het project. ${ }^{29}$ In het jaarverslag van het genootschap in de Javasche Courant werd ruime aandacht besteed aan Van Kinsbergens werkzaamheden te Diëng. Het genootschap was daarover zo tevreden, dat hij de titel van 'photograaf des Genootschaps' verwierf. De enthousiaste secretaris Levyssohn Norman, noemde het gebied 'het Benares van Midden-Java'. ${ }^{30}$

Van Kinsbergen vervolgde zijn 'kunstreizen', zoals deze missie door het gouvernement werd aangeduid. Zijn status werd hoe langer hoe meer die van de fotograaf-kunstenaar én deskundige-archeoloog. Hem werd toegestaan

uit de steenbrokken, in den omtrek der Hindoe-tempels en bouwvallen verspreid liggende, ten behoeve van het museum van het Bataviaasch genootschap zoodanige uit te kiezen, als uit een architectonisch oogpunt door hem bijzonder merkwaardig worden geacht. ${ }^{31}$

Deze interessante bij-opdrachten en nevenactiviteiten vertraagden de aflevering van de driehonderd foto's. In juli 1866 moest de opdracht daarom met een jaar worden verlengd tegen een vergoeding van $f 1000$ per maand en $f 200$ voor transportkosten. (De dagloners die op Diëng het graafwerk verrichtten, verdienden $f 0,25$ tot $f 0,30$ per dag. ${ }^{32}$ ) Op 25 september 1866 schreef het genootschap een ongeduldige brief over zijn verblijf van twee maanden in Batavia. Van hem werd verwacht dat hij onverwijld het reizen zou hervatten. Van Kinsbergen antwoordde op 16 oktober en verklaarde zich bereid te vertrekken. ${ }^{33}$ In november 1866 ging hij voor zijn vierde contractjaar op pad. In januari 1867 meldde het genootschap dat het al twee maanden niets van hem had vernomen. Pas in juli kwamen er 167 opnames uit Kediri, Penataran en omgeving. In Penataran waren opnieuw opgravingswerkzaamheden nodig

29 Notulen 3:43, vergadering 7-4-1865. Verslag van die commissie in Notulen 3:108, vergadering 7-7-1865.

30 Javasche Courant, extra bijvoegsel 20-6-1865, nr 50, p. 2-3. De benoeming was geschied op 10-2-1865, Notulen 3:26.

$31 \quad$ Notulen 3:3, vergadering 10-2-1865.

32 Notulen 4:188, vergadering 31-7-1866.

33 ANRI KBG Mus 0029, conceptbrief aan van Kinsbergen. Uit zijn bijgevoegde antwoord van 16-10-1866 blijkt de genootschapsbrief te dateren van 25-9-1866. 
geweest. Toen de foto's in september 1867 op het Koningsplein werden bekeken, bleek het bestuur weer uitermate tevreden. Het had dan lang moeten wachten, de kwaliteit van het afgeleverde werk was zeer hoog. ${ }^{34}$ Nog lang na het afronden van zijn reis talmde Van Kinsbergen met het maken van de zes contractueel vastgelegde afdrukken van ieder cliché. Pas in februari 1872, ruim negen jaar na het sluiten van het contract, leverde de fotograaf de eerste complete set van 332 foto's af, waarna er nog vijf sets moesten volgen. De naam van de fotograaf was echter na het uitkomen van dit album Oudheden van Java gevestigd, ook internationaal. Dat hij sommige plaatsen zeer uitgebreid opnam (tientallen foto's van Diëng en Penataran), terwijl andere belangrijke plaatsen (Prambanan) met maar enkele foto's vertegenwoordigd waren en andere helemaal niet, had de begeleidingscommissie niet kunnen voorkomen. ${ }^{35}$ Het was in belangrijke mate een gevolg van de koppeling van Van Kinsbergens werk aan de uitkomsten van Brumunds reis en diens plotselinge dood. De predikant was van plan geweest om ook de Boroboedoer weer te bezoeken, maar was daar niet meer aan toe gekomen. Verder was de fotograaf een eigenzinnig man en maakte hij zijn eigen keuzes. Daarbij had het genootschap hem ook meer vrijheid gelaten dan in 1862 was afgesproken, en wel als teken van vertrouwen van de kant van het bestuur. Het maakte niet uit voor de manier waarop de foto's werden ontvangen, die nog steeds gelden als belangrijke documenten in de geschiedenis van de bestudering van de oudheden op Java. ${ }^{36}$ Losse afdrukken werden in Batavia via de studio van Ernst en Co te koop aangeboden, waardoor ook een ruimer publiek er kennis mee kon maken.

Van Kinsbergen kreeg in 1872 nog een tweede opdracht om veertig foto's te maken voor een album over de Boroboedoer. ${ }^{37}$ Conrad Leemans kon niet nalaten een en ander aan te merken op de Oudheden van Java, toen de foto's Leiden bereikten. De opdracht voor de Boroboedoer-foto's vond hij zelfs een onnodige geldverspilling. Zijn eigen Bôrô-Boedoer met de litho's naar de tekeningen van Wilsen was net uit en maakte verdere documentering overbodig. Het weerhield het genootschap er niet van om met trots voort te werken aan het tweede album van de 'photograaf des Genootschaps'. Dat Leemans zich erover beklaagde, dat hij niet was gehoord in de aanloop tot het verlenen van de tweede opdracht - hij was immers dé expert ter zake van die tempel - tekent de rivaliteit die hij voelde tussen het genootschap

34 Notulen 4: 249, vergadering 30-10-1866; Notulen 5:10 (vergadering 29-1-1867), 23 (vergadering 26-3-1867), 75 (vergadering 30-7-1867) en 86 (vergadering 22-9-1867).

35 Van Kinsbergen 1872, in Notulen 10:bijlage 2 bij vergadering 5-3-1872.

36 Zie over het belang van Van Kinsbergens 'Photographiën naar oudheden van Java': Krom 1923, I: 20-3; Theuns-de Boer en Asser 2005.

37 Van Kinsbergen 1874 in Notulen 12:bijlage f bij vergadering 9-6-1874. 
en zijn eigen museum. Leemans' opmerkingen leidden zelfs tot vragen van de minister van koloniën, of het Boroboedoer-project van Van Kinsbergen wel door moest gaan (1873). Leemans was echter niet kleinzielig en erkende dat Van Kinsbergens Oudheden 'eene onschatbare bijdraag tot de kennis van den oorspronkelijken [staat der oudheden] en eene wezenlijke winst voor de wetenschap' vormde. ${ }^{38}$ Het feit dat de uitvoering van het Boroboedoerproject ook weer aanleiding gaf tot opgravingen en herstelwerkzaamheden ${ }^{39}$ bevestigde de positie van het genootschap als de organisatie die zich met hulp van de overheid bezighield met oudheidkundig onderzoek, opgravingen en restauraties op Java. De glasnegatieven van Van Kinsbergen zijn in het begin van de twintigste eeuw door het genootschap overgedragen aan de Oudheidkundige Dienst, de organisatie die in 1913 voor het beheer van de oudheden was opgericht (nu Dinas Purbakala), waar ze nu nog zijn. De taken van het genootschap op het terrein van de oudheden hadden zich toen verzelfstandigd.

Het bestuur raakte door de missies van Brumund en Van Kinsbergen steeds beter op de hoogte van de toestand van de oudheden, vooral van de deplorabele toestand van sommige tempelruïnes. Diëng en Penataran kwamen erdoor op de archeologische kaart te staan. Vooral de alertheid van bibliothecaris Van der Chijs, die rechtstreeks in contact stond met Van Kinsbergen, treft in de bestuursverslagen. Het genootschap werd daardoor een waakhond. Van der Chijs' opmerking in 1863 over Brumunds observatie over het afbreken van de Bagong-tempel (Diëng) - stenen van die tempel werden op de markt in Batoer verkocht - was aanleiding tot een brief aan het gouvernement, waarna dat maatregelen nam om de oudheden beter te beschermen. ${ }^{40}$ Daarbij kwam het genootschap terug op eigen voorstellen uit 1860 voor het betere beheer van oudheden op Java. Het gouvernement ging niet over tot strafbaarstelling, maar gebruikte termen als 'met leedwezen' om aan te duiden dat de zorg voor de oudheden niet was zoals gewenst. Het deed een beroep op de 'goeden wil en den wetenschappelijken zin der hoofden van gewestelijk en plaatselijk bestuur'. Dat moest voldoende zijn om te leiden tot beter onderhoud en moest roof en vernieling voorkomen. Dat echter geen sancties werden getroffen, verzwakte het standpunt van de regering. ${ }^{41}$

In 1865 was het opnieuw Van der Chijs die de zorg voor de oudheden

38 Notulen 11:102-4 (vergadering 19-8-1873) en 162 (vergadering 22-12-1873). In de notulen is de brief van Leemans geciteerd. Enkele woorden lijken echter te zijn weggevallen, die ik hier tussen vierkante haken heb gereconstrueerd.

39 Verslag van Van Kinsbergen over zijn Boroboedoer-opdracht in Notulen 12 :71-6, vergadering 9-6-1874.

$40 \quad$ Notulen 1:190-1, vergadring 18-4-1863.

41 Notulen 1:242-8, vergadering 12-9-1863. Daar wordt het gouvernementsbesluit van 18-81863 geciteerd. 
onder de aandacht van het bestuur bracht, waarna hij in januari 1866 adviseerde om het gouvernement een aantal maatregelen voor te stellen. Eerst gaf hij een reeks tempels en ruïnes op die voor geregeld onderhoud in aanmerking kwamen. Daarna vroeg hij vooral aandacht voor de verzorging van het Prambanan-complex en wees op de 'fraaije beelden van Loro Djonggrang, die men gaarne in 's genootschaps museum voorgoed bewaard zag.' 42 Dat gebeurde niet. De betreffende beelden bevinden zich nog steeds in situ. Hij adviseerde ook nader onderzoek naar de tempels op de hellingen van de Lawoe en de Smeroe. Dat beelden beter konden blijven waar ze waren, was te Batavia niet doorgedrongen. Tijdens dezelfde vergadering van januari 1866, waarin Van der Chijs' advies werd besproken, werd ook geprobeerd om de beelden op het terrein van het residentshuis te Kediri en een kolossale Ganesha uit Blitar voor het museum te verkrijgen. ${ }^{43}$ Voor wat betreft die in Kediri was dat in 1851 al eens geprobeerd. De Ganesha staat nog steeds in Blitar.

Het duidelijkst komt de rol van adviserend lichaam in oudheidkundige zaken tot uiting in de rol die het genootschap speelde bij de opgravingen te Diëng, die door Van Kinsbergen waren begonnen. Diens verslag had het genootschap er in augustus 1864 meteen toe aangezet het gouvernement maatregelen in overweging te geven. De begonnen opgraving moest worden voortgezet, er moest een budget voor worden vastgesteld, de lokale autoriteiten moesten verantwoordelijk worden voor de uitvoering van het project. ${ }^{44}$ Een uitgebreider verslag van 30 september 1864 - Van Kinsbergen was toen ruim twee maanden aan het werk op Diëng - bewerkte de rest. Het genootschap werd gevraagd om advies te geven over de aanbevelingen van de resident van Bagelen, Castens, die onder meer de reconstructie van een afwateringskanaal en een administratieve herindeling van residenties voorstond. De grens tussen de residenties Bagelen en Banjoemas liep precies over het plateau, wat de goede uitvoering van het opgravingsproject bemoeilijkte. Daarop stuurde het genootschap in mei 1865 de al genoemde commissie van drie bestuursleden naar Diëng om ter plaatse te beoordelen of de aanbevelingen van Castens opgevolgd moesten worden. ${ }^{45}$ In het verslag van die commissie week zij nogal af van de de mening van de resident. De herindeling was wel een goed idee, maar moest niet lopende het opgravingswerk worden doorgevoerd. Het afwateringskanaal moest niet worden gerestaureerd. Het gouvernementsbesluit van 4 maart 1866 volgde bijna geheel de aanbevelingen van de commissie van drie en van het genootschapsbestuur. Het opgravings-

$42 \quad$ Notulen 4:7-9, vergadering 16-1-1866.

43 Notulen 4:9, vergadering 16-1-1866.

44 Notulen 2:226, vergadering 16-9-1864.

$45 \quad$ Notulen 3:43, vergadering 7-4-1865. 
project werd gedoteerd met een subsidie van $f 5.000$ en de uitvoering werd in handen gegeven van Kiay Soero Semito uit Batoer, terwijl de eerstaanwezend ingenieur van Bagelen, G.A. Pet, maandelijks de voortgang zou inspecteren en daarvan het gouvernement via het genootschap verslag zou doen. ${ }^{46}$ In de loop van 1866 zou Pet, inmiddels tot lid benoemd van het genootschap, rapporteren over de voortgang van de opgravingen (Notulen 4:176, 187, 232, 257, 5:44, 60, 88, 6:54). Het genootschap ontving intussen de al door Van Kinsbergen opgegraven kleinere voorwerpen voor het museum, terwijl de grotere stenen en beelden bij de Passangrahan te Diëng bleven. Later zou een deel van die verzameling alsnog naar Batavia verhuizen. Diëng was aldus het paradepaardje van het genootschap. Het belang van het complex is nog steeds groot, getuige het aantal bezoekers dat het nog in onze eeuw trekt. Het 'project Diëng' was tegelijk het concrete bewijs aan het adres van de bezorgde Leemans dat het bestuur, ondanks wisselingen, in staat was in nauwe samenwerking met het gouvernement te zorgen voor de Javaanse oudheden. Op het gebied van het beheer van oudheden op Java speelde het genootschap nu een centrale rol. Gouverneur-generaal Sloet van de Beele was op dit terrein een actieve factor. Hij was persoonlijk geïnteresseerd in de zorg voor Java's oudheden en koos voor een zwaardere rol voor het genootschap in Batavia boven de verre Leemans in Leiden. Hij stelde ook belang in de foto's die Van Kinsbergen op Java maakte en liet die naar zich toebrengen om ze te kunnen bekijken. Van Kinsbergen begeleidde de gouverneur-generaal op een van zijn reizen. Als beschermheer van het genootschap kan Sloet het best vergeleken worden met zijn voorganger Van der Capellen, een halve eeuw eerder.

\section{Verzamelingen: archeologische voorwerpen}

De kommervolle omstandigheden waaronder de museumcollecties en de bibliotheek tot eind 1867 waren ondergebracht, waren nog geen reden om de verzameltaak te verwaarlozen, die het genootschap zich gesteld had. Onderhuurder Lange, die in 1848 de drukkerij had overgenomen en in de bijgebouwen was blijven werken, beklaagde zich in juni 1862 over de slechte staat van de door hem gehuurde ruimtes, waarvoor het genootschap nog zeshonderd gulden per jaar aan huur ontving. ${ }^{47}$ In 1865 koos de drukker eieren voor zijn geld en vertrok, ook al met het oog op de op handen zijnde verhuizing van het genootschap. ${ }^{48}$ Door Langes vertrek was meer ruimte beschikbaar.

$46 \quad$ Notulen 4:82, vergadering 27-3-1866.

47 TBG 12:563, vergadering 7-6-1862.

48 Het verslag van 11-5-1865 in Notulen 3:69 vermeldt het vertrek van Lange. 
In de periode van vijfeneenhalf jaar, gelegen tussen de beslissing over de nieuwbouw en het betrekken van het gebouw, was het genootschap bepaald actief op acquisitie-gebied. Het deed bovendien zijn best om de collecties fatsoenlijk uit te stallen. Het mocht dan op een pakhuis lijken, er heerste orde. Brumund had vóór zijn vertrek op zijn grote reis van 1862 de oudheidkundige verzameling bekeken en de beelden 'in fraaije groepen gerangschikt naar de goden of het tijdvak dat deze vertegenwoordigen'. Verder heerste in de kasten het geografische principe: 'zoveel mogelijk steeds alles bijeen wat tot dezelfde landstreek behoort'. ${ }^{49}$ Jammer genoeg beschikken we niet over beschrijvingen door bezoekers aan de Rijswijkstraat in deze periode en evenmin over foto's, waaruit we ons een beter beeld kunnen vormen. De geruststelling uit eigen bestuurskring (1862), dat de nieuwe beschermheer, Sloet van de Beele, zelf had kunnen vaststellen dat de collecties er goed bijstonden, leest als een bezwering en was vooral bedoeld om het toen dreigende oprukken van de Leidse confraters af te wenden. ${ }^{50}$

De gedrukte notulen, tot augustus 1862 in het Tijdschrift, daarna in aparte jaarbundels Notulen, bieden ons een ingang tot het onderwerp van de aanwinsten, maar het beeld van de werkelijke toestand in het museum in de laatste jaren van de Rijswijkstraat wordt er niet veel scherper op. De registers op deze notulen door de hoofd-ingenieur chef der telegrafie, H.L. Janssen (1868), en J.A. van der Chijs (1879) zijn een godsgeschenk. De afdelingen 'oudheden' en 'land- en volkenkunde' nemen in deze registers de meeste plaats in, gevolgd door 'taal- en letterkunde' in het eerste en de 'bibliotheek' in het tweede register. De onvolprezen Van der Chijs zou de hele rest van de 19e eeuw ijverig registers blijven maken, waar we nu nog de vruchten van plukken. Zijn drie registers $(1879,1889,1899)$ zijn voor de hele periode van 1867 tot 1898 een belangrijke ingang tot de genootschapsgeschiedenis. Na zijn aftreden als bestuurslid in 1900 - hij stierf in 1905 - is soortgelijke arbeid voor latere perioden niet meer ondernomen. Uitgebreide lijsten en overzichten achterin ieder deel vormen de tijdrovende zoekmiddelen voor de Notulen na 1898.

Bepalen we ons eerst tot de oudheidkundige collectie. Die was vooral op Java gericht. Op het gebied van de oudheidkunde had Java natuurlijk door de rijke bewoningsgeschiedenis het meeste te bieden, zowel aan resten van grote als kleine tempelcomplexen. Daarbij vergeleken liepen de buitengewesten achter. Die waren minder geëxploreerd, ook dunner bezaaid met ambtenaren en militairen, die het genootschap moesten voorzien van materiaal, aanwijzingen, gegevens, aanwinsten. Vooral Midden-Java, de residenties Banjoemas, 
Bagelen en Kadoe, leverde aanwinsten op. Daarop volgde de omgeving van Soerabaija, Pasoeroean, Malang en Probolinggo. Van deze gebieden was Bagelen veruit het best vertegenwoordigd. Het bezoek van Brumund, maar vooral de erop gevolgde, door Van Kinsbergen begonnen opgravingen op Diëng, betekenden de start van een ware schatgraverij.

De toenemende stroom aanwinsten die via het gouvernement binnenkwam als gevolg van de overheidsmaatregel van 1855, vraagt om nadere beschouwing. Om het verloren gaan van opgegraven objecten, tegen te gaan, had het gouvernement in dat jaar bepaald dat het kon besluiten wat er met opgegraven geld of waardevolle voorwerpen zou moeten gebeuren. Het kwam neer op een meldingsplicht voor de bestuursambtenaren die van vondsten lucht kregen. ${ }^{51}$ De vondst werd dan aan het bestuur van het genootschap voorgelegd met de vraag of het er belangstelling voor had en of het bereid was ervoor te betalen. Omdat de betaling was gebaseerd op de metaalwaarde van het voorwerp, waren de prijzen voor het bestuur aantrekkelijk. Er was nog nauwelijks een markt die bepaalde hoe de artistieke of oudheidkundige waarde kon worden gekapitaliseerd. Een andere mogelijkheid was, als het genootschap van overname afzag, de openbare verkoop van de vondst. Op basis van deze regeling was een praktijk ontstaan waarbij het genootschap een aanbod kreeg, dat het beoordeelde (kopen of niet?). In 1861 voegde het genootschap in een brief aan de hoofden van de gewesten eigener beweging aan deze praktijk toe dat het niet alleen in vondsten in edele metalen, maar ook in opgegraven voorwerpen in steen en niet-edele metalen was geïnteresseerd. ${ }^{52} \mathrm{Na}$ het gouvernementsbesluit van 1862 over de reis van Brumund was ook de aankoop voor Leiden een van de mogelijkheden geworden.

In 1857 kwamen nog maar vier van deze aanbiedingen van het gouvernement binnen, terwijl bij een vijfde niet vermeld staat of het een aanbod van het gouvernement was. ${ }^{53}$ In 1861 was de stroom nog steeds tamelijk beperkt: er is van slechts drie vondsten sprake. Het ging om drie koperen voorwerpen, een metalen klok en een ring met een boeddha-afbeelding. Het eerste voorwerp,

\footnotetext{
51 TBG 12:186, algemene vergadering 16-11-1861.

52 TBG 12:186-7, algemene vergadering 16-11-1861.

53 TBG 7:186, vermeldt een brief van de eerste gouvernements-secretaris van 28-10-1856 over acht goudwerken uit Probolinggo. Een brief van dezelfde van 13-11-1856 over 'eenige goud- en zilverwerken' gevonden in Geling (Jepara), aangekocht voor $f$ 35,92 en 27 duiten. Een soortgelijke brief van 16-12-1856 bood een aarden pot aan met zes bellen en een stuk kristal. De koop werd gesloten voor $f$ 20. Dit alles ter vergadering van 23-2-1857 (Notulen 7:187). Van de eerstgenoemde goudwerken werd op de vergadering van 6-4-1857 een gouden 'kroon- of koeloetornament' gemeld als gekocht (Notulen 7:250). Op 27-7-1857 werden twee oude gouden oorringen uit de buurt van Bidara-Cina gekocht voor $f 15$ gekocht. Niet vermeld wordt of het een aanbieding van het gouvernement is (Notulen 7:457). Tenslotte kwam er aan het eind van het jaar nog een brief binnen van het gouvernement, 20-11-1857 over drie koperen schenkbladen, een potje en een bidkrans, die voor $f 13$ werden overgenomen (TBG 8:2, vergadering 28-12-1857).
} 
afkomstig van Bangka, werd als niet waardevol genoeg afgeslagen, de andere, beide uit Bagelen afkomstig, werden voor respectievelijk $f 20$ en $f 100$ aangekocht. ${ }^{54}$ Het jaar 1861 leek armetierig te zijn voor de oudheidkundige aanwinsten, maar wel kwamen in dat jaar de Bandjarmasinse rijkssieraden binnen, die historisch-antropologisch interessant waren. Een probleem vormt hierbij dat aan de term 'oudheidkunde' een ruime betekenis werd gegeven, zodat voorwerpen die wij in de twintigste eeuw niet als 'oudheidkundige aanwinst' zouden bestempelen, dat in de negentiende eeuw wel konden zijn.

Pas echt ging de stroom aanbiedingen via het gouvernement vloeien in 1863. Toen kwamen er meer dan twintig binnen. Toen ook werd van voorwerpen voor het eerst gemeld dat zij aan de antiquarische of archeologische verzameling werden toegevoegd, waarbij de oudere geschiedenis van de nieuwere gescheiden leek te zijn. ${ }^{55}$ In maart 1863 meldde het jaarverslag dat er sinds november 1861 vijftien oudheidkundige voorwerpen waren aangekocht (Notulen 1:162). Het lijkt alsof de komst van Sloet van de Beele in oktober 1861 direct tot grotere activiteit aanleiding had gegeven. In de rest van het jaar 1863 volgden nog zestien meldingen (Notulen 1:179, 193, 249, 283, 287). Daarbij werden voor het eerst ook de belangen van Leiden in de gaten gehouden. Pas als het genootschap in Batavia van aankoop afzag, suggereerde het aan het gouvernement om het besproken voorwerp voor Leiden aan te kopen. Zo kon bijvoorbeeld een gouden ring uit Banjoemas met een metaalwaarde van $f 40$, waarvan al voorbeelden in de collectie te vinden waren, voor Leiden worden bestemd (Notulen 1:41, 65-6). De opbrengst ging steeds, naar de formulering van het gouvernementsbesluit, 'voor de helft naar de vinder en voor de wederhelft naar het bestuur der dessa, waar het voorwerp gevonden is, ter verdeeling onder de bewoners dier dessa of om ten meesten nutte van de gemeente te worden aangewend' (Notulen 1:66). Zo was een mooi midden gevonden tussen de belangen van de vinder en de belangen van de gemeenschap. Wat de rol bleef van de vrije markt, van opkopers die zelf de vinders wisten op te sporen of bij wie de vinders zelf hun vondsten kwamen aanbieden, is moeilijk na te gaan. Zo'n markt is er ongetwijfeld geweest.

Tot de belangwekkendste aankopen van deze periode behoort een in 1863 in de residentie Kadoe, dessa Paingan opgegraven gouden boeddha-beeldje op een zilveren voetstuk met een zilveren rugplaat, waarvan de metaalwaarde op $f 732$ werd geschat. Het is in werkelijkheid een vierarmige Wisnu van bijna 19 centimeter hoogte. Om de uitzonderlijke kwaliteit van het beeldje besloot het genootschap op het aanbod van de regering in te gaan, 'al gaat

54 TBG 11:420, vergadering 2-3-1861 voor de aangeboden koperen voorwerpen. De metalen (bronzen?) klok wordt gemeld in de vergadering van 13-7-1861, TBG 12:118. Daar ook de eerste vermelding van de gouden boeddha-ring. (Pagina 133 en 143 voor de sluiting van de koop.)

55 Notulen 1:71 (antiquarisch) en 76-7 (archeologisch), vergadering 23-1-1863 en 24-2-1863. 
de overname dan ook met belangrijke geldelijke opofferingen gepaard. ${ }^{56}$ In januari 1864 was de overname een feit. Het beeldje kon worden gerepareerd en werd vervolgens, om de waarde, bij de thesaurier in bewaring gegeven. Bij de jaarvergadering van 30 april 1864 werd het als een van de mooiste beeldjes uit de collectie naar voren geschoven. Het werd tentoongesteld in het Nederlandse paviljoen op de Internationale Koloniale Tentoonstelling in Parijs in 1931, waar het als door een wonder, als enige van de voorwerpen uit de Bataviase schatkamer, ontkwam aan de brand, zij het beschadigd. De conservator van de oudheidkundige afdeling schreef in 1931, nadat de schamele resten van de bruikleen waren terugontvangen in het museum, over de schade geleden in de schatkamer:

Niet minder dan veertien gouden en vier zilveren godenbeeldjes werden door de brand vernietigd, meer dan twee derde van wat de collectie in totaal aan deze voorwerpen bezat. Het eenige beeldje waarvan een - zwaar verminkt - overblijfsel werd terugontvangen is no. 486 , staande vierarmige Wisnu. ${ }^{57}$

Het beeldje verloor in de brand de zilveren rugplaat, maar het zilveren voetstuk bleef gespaard. Het was in 1992 te zien op de tentoonstelling 'Het Goddelijk gezicht van Indonesië' in de Nieuwe Kerk te Amsterdam. ${ }^{58}$

Zelfs niet in de buurt van die hoge waarde van voornoemd beeldje kwam een gouden armband die in Rembang was gevonden en waarop twee tekens gegrift stonden, die de aandacht van het bestuur trokken. Voor $f 225$ nam het gouvernement de armband ten behoeve van het museum over. ${ }^{59}$ Het kon ook anders aflopen. In 1866 vond Pak Boengeng in de dessa Goenoeng Toegil (Probolinggo) een koperen busje met gouden en andere metalen voorwerpen dat het genootschap werd aangeboden voor $f 275$. Het genootschap wilde er niet meer voor geven dan de metaalwaarde, $f$ 185,11. Het gouvernement kwam er nog eens op terug: in Probolinggo zouden de voorwerpen voor circa $f 275$ verkocht kunnen worden. Het genootschap zwichtte niet en dus ging het busje met inhoud naar Probolinggo terug voor een verkoping, waarvan de opbrengst voor de helft naar Pak Boengeng zou gaan. In 1865 zag het genootschap twee keer van een kostbare vondst af ten gunste van Leiden: $f$ 160,65 en $f 115,25$ voor tweeëntwintig gouden boeddha-voorwerpen, vierendertig zilveren munten en nog eens elf gouden voorwerpen, alle uit de residentie

56 Notulen 1:305-6, vergadering 12-12-1863. Het beeldje was gevonden ten oosten van de dessa Paingan, residentie Kadoe en aan het genootschap aangeboden bij een brief van de eerste gouvernementssecretaris dd 2-11-1863.

57 Bosch en Le Roux 1931:672. Over de tentoonstelling en de brand: Bloembergen 2003:271316.

58 Fontein 1990:205-6, waar overigens in verband met dit voorwerp aan de brand, noch aan de schade gerefereerd wordt. Bij Fontein ook een afbeelding.

$59 \quad$ Notulen 1:81 (vergadering 24-2-1863) en 179 (vergadering 18-4-1863). 
Bagelen afkomstig. ${ }^{60}$

Al met al was het onderwerp 'overname' van opgegraven waardevolle voorwerpen niet meer weg te denken uit de bestuursvergaderingen. Het was echter niet de enige manier waarop de collectie werd aangevuld. Schenking bleef de meest voorkomende manier. Tegenover de vijftien aangekochte oudheidkundige voorwerpen, die het jaarverslag van 1863 meldde, stonden er drieëntwintig die door diverse personen waren geschonken. Vooraan stond gouverneur-generaal Sloet van de Beele, die vanaf zijn eerste reis naar Midden- en Oost-Java, de reis waarop hij Van Kinsbergen meenam, de belangen van het genootschap in het oog hield. Vier stenen met inscripties en twee voetstukken van lingga's (Soerabaija), vijf metalen voorwerpen uit Kadoe, en koperen, gouden en stenen sieraden van de landen van de Mangkoe Negoro, alle gemeld in de notulen van 2 augustus 1862, vonden hun weg naar het museum. ${ }^{61}$ Precies een jaar later was Sloet van de Beele weer in Midden-Java, waarvandaan hij een nieuwe schenking van onder meer twee inscripties en twee Nandi's meenam, terwijl de regent en de resident van Bandjar Negara aan Sloet in totaal zeven andere archeologische voorwerpen meegaven. ${ }^{62}$ Van een reis naar Oost-Java aan het eind van 1865 bracht de beschermheer wederom een aantal beelden en stenen mee, terwijl hij ook de aandacht vestigde op de grote beelden te Singosari, die al door Van Kinsbergen waren gefotografeerd.

Den resident heb ik opgedragen te onderzoeken, wat bij onderhandsche uitbesteding het vervoer van die voorwerpen met kleinere van Malang en een grooten beschreeven steen van Ngantang naar Soerabaija zoude kosten. Zijn die voorwerpen eens daar, dan zal dat vervoer naar hier weinig bezwaar opleveren. ${ }^{63}$

Het is duidelijk dat Sloet een voorstander was van het samenbrengen van archeologische vondsten in Batavia. Het denkbeeld dat beelden en stenen beter konden blijven waar zij waren, was niet aan hem besteed. Het citaat tekent Sloets belangstelling voor de zaken van het genootschap. Hij liet blijken dat hij zijn beschermheerschap serieus nam. Dat hij de taken van het museum breder zag dan het nog niet lang tevoren definitief afgeperkte gebied van de taal-, land- en volkenkunde van de archipel, blijkt uit andere schenkingen, waaronder een bronzen medaille geslagen door de provincie Gelderland ter herinnering van de hulp geboden door Willem III bij de watersnood van 1861 (Notulen 1:177). Sloet van de Beeles vertrek in oktober 1866 kwam een jaar vóór het gereedkomen van het museum aan het Koningsplein. Terug in Nederland

$60 \quad$ Notulen 3 (1865):35-6, 91, 131, 155.

61 TBG 12:586. Zie ook Notulen 1:162, jaarverslag.

62 Notulen 1:238, vergadering 1-8-1863.

63 Notulen 4:1-2, vergadering 16-1-1866. 
zette hij Van der Tuuk in voor de bestudering van zijn collectie Lampongse handschriften, terwijl hij voor de Koninklijke Akademie te Amsterdam sprak over de studie van de inheemse talen (Groeneboer 2002). De vergelijking met Van der Capellen dringt zich weer op. Deze immers toonde tijdens, maar ook na zijn Indische verblijf weer terug in patria, belangstelling voor de taal-, land- en volkenkunde van Nederlands-Indië.

Anderen, bestuursleden én gewone leden, behoorden eveneens tot de begunstigers van het genootschap. De tot erelid benoemde Netscher stuurde in 1862 vanuit zijn nieuwe standplaats Riouw een gebeeldhouwde kop en een gebakken steen, afkomstig van een hindoe-ruïne bij Kota Pinang (Siak). ${ }^{64}$ Van der Chijs droeg onder meer twee boeddha-hoofden bij, vermoedelijk van de Boroboedoer afkomstig en later nog een hindoe-kris (Notulen 2:264, 315). Het gewoon lid, de gouvernementssecretaris A. Loudon, bracht in januari 1862 vier kleine stenen Ganesha's aan, aangeduid als 'voorwerpen van ethnologischen aard', en een paar maanden later nog eens vijf beelden uit de hindoe-tijd. Toen hij later dat jaar terugkwam van zijn gezantschapsreis naar Siam nam hij diverse Thaise voorwerpen mee voor de collectie. ${ }^{65}$ Loudon werd in november 1864 tot bestuurslid en direct tot voorzitter gekozen. Zijn belangstelling voor het genootschap was voldoende geweest om hem meteen op deze post te brengen.

De fotograaf van het genootschap, Van Kinsbergen, droeg vruchten van zijn opgravingen bij Diëng aan. ${ }^{66}$ Ook schilder en genootschapslid Raden Saleh droeg oudheden bij. Door hem aangeboden koperen platen met inscripties werden bij de jaarvergadering van 1866 speciaal vermeld vanwege hun ouderdom (Notulen 4:145). De lijst is niet volledig, maar geeft aan hoeveel particuliere personen konden verwerven. Er ging veel van hand tot hand en veel bleef in particulier bezit. Het voorbeeld van beschermheer Sloet van de Beele had in ieder geval het effect dat het tot navolging opriep. De overheid zelf was uiteraard een groot leverancier van voorwerpen.

Het is niet eenvoudig om, ondanks al deze meldingen in de notulen, een beeld te krijgen van wat er in de periode tot de opening van het nieuwe museum binnenkwam. De omschrijvingen zijn veelal vaag. Nummers en precieze aanduidingen van de herkomst ontbreken in de notulen. Dateringen worden zelden gegeven, terwijl, om de zaak nog ingewikkelder te maken, archeologische en etnologische aanwinsten door elkaar worden opgesomd, zodat soms op basis van de vage omschrijving niet valt op te maken om wat voor een aanwinst het gaat. Toch werd ook hier, stapsgewijs, vooruitgang

64 TBG 12:228, vergadering 7-6-1862.

65 TBG 12:229 (vergadering 4-1-1862), 536 (vergadering 5-4-1862) en 548 (vergadering 3-51862).

66 Notulen 3:25, vergadering 10-2-1865; 4:87, vergadering 27-3-1866. 
geboekt. Levyssohn Normans Katalogus van de ethnologische afdeeling (1868) bracht een scheiding aan in de collectie. Dat Levyssohn Norman deze catalogus samenstelde en dat deze gedrukt werd, is nog bewonderenswaardiger als we dit afzetten tegen de lijdensweg die de catalogus van de archeologische afdeling wachtte. W.P. Groeneveldt kreeg in 1877 toestemming om tot drukken ervan over te gaan. ${ }^{67}$ Hoewel deze lijdensweg grotendeels buiten het tijdsbestek van dit boek valt, dient er hier enige aandacht aan te worden besteed omdat de naam van Friederich er aan verbonden is.

Friederich had zich in juni 1863 gemeld bij het genootschap en vond het bestuur bereid van Brumunds papieren afschriften te laten maken ten behoeve van zijn regeringsopdracht. ${ }^{68}$ Daarmee leek de verhouding tussen de voormalige adjunct-bibliothecaris en het genootschap weer in orde. $\mathrm{Na}$ 1863 bleef Friederich uit het blikveld van het genootschap. Over de vorderingen die hij maakte bij het verzamelen van inscripties en de bestudering ervan leest men in de notulen niets. Sloet van de Beele schreef in 1866 in zijn lijvige memorie van overgave over de verplichting die Friederich had om halfjaarlijks over de voortgang van de opdracht te rapporteren. 'Hieraan heeft hij nimmer voldaan, niettegenstaande herhaalde aanmaningen.' Hij voegde er vergoelijkend aan toe, 'dat het aan geleerden, die zich met een onderzoek van grooten omvang bezig houden, moeijelijk te vergen is op gezette tijden verslag van hunnen arbeid te doen'. ${ }^{69}$ Toen Friederich in juni 1868 eindelijk met een verslag kwam, was dat voor de directeur van onderwijs, L.W.J. de Waal, aanleiding om advies te vragen aan het genootschap, onder meer omtrent de vraag 'welke maatregelen zouden kunnen worden genomen om van de aan de ambtenaar Friederich opgedragen werkzaamheden spoedige en goede uitkomsten te verkrijgen'. ${ }^{70}$ Het oordeel van het genootschap was hard. Friederich kon beter van zijn taak worden ontheven.

Eene opdragt als die van de Regering aan de Heer Friederich is geheel eene zaak van vertrouwen. Wordt dat beschaamd en blijven alle aansporingen vruchteloos, dan is, dunkt ons, de eenige afdoende maatregel, die te nemen valt, aan zoodanige opdragt een einde te maken.

Het verslag van Friederich van juni 1868 werd 'een uiterst schrale oogst van vijfjarigen wetenschappelijke nasporingen' genoemd.

67 De voltooiing van de catalogus zou nog tien jaar vergen (Notulen 15:118-9, vergadering 7-81877).

68 Notulen 1:223-6, brief van Friederich, 26-6-1863.

69 NA Koloniën 2.10.03 nr 24 'Overzicht van den Staatkundigen toestand van Nederlandsch Indië op het tijdstip der aftreding van den Gouverneur Generaal Sloet van de Beele.' 1866, p. 1471-2.

70 ANRI KBG Dir 0997, citaat uit het antwoord van het genootschap, 4-3-1869 nr 24. 
Van de hem oorspronkelijk opgedragen verzameling, bewerking en verklaring der oud Ind. opschriften op steen en in metaal, welke steeds door hem als hoofdzaak had behoren te worden aangemerkt, vindt men daarin nagenoeg geen spoor. [...] Het geheel draagt het kenmerk van met overhaasting te zijn zamengesteld om tot bevrediging der Regering toch maar het een en ander te leveren. Grote wetenschappelijke waarde heeft het niet. ${ }^{71}$

Gezien het persoonlijke karakter van de zaak, werden de stukken over de beëindiging van de opdracht niet in de Notulen geplaatst. In het archief zijn ze echter te vinden. ${ }^{72}$ In februari 1869 had Friederich een aanvrage gedaan om met ziekteverlof te kunnen gaan. Dat verzoek werd niet ingewilligd. Friederich werd eervol ontslagen waarna in juni 1869 het besluit volgde hem pensioen te verlenen. Dat er teleurstelling was over het niet afronden van de inscriptie-opdracht, is duidelijk (Krom 1923, I:17-8).

Voordat het tot Friederichs ontslag kwam, had het genootschap nog eens een beroep op hem gedaan. Toen eind 1867 de archeologische verzameling in het nieuwe museum zou worden opgesteld, deed zich de behoefte aan een catalogus van die collectie opnieuw voelen, te meer waar die van de etnologische collectie door Levyssohn Norman al was gemaakt. Het was Cohen Stuart, die op 14 januari 1868 voorstelde

den heer R.H.Th. Friederich uit te noodigen, om den catalogus der archeologische verzamelingen des Genootschaps, waarmede hij reeds voor 20 jaren met Dr. W.R. van Hoëvell een aanvang heeft gemaakt, te willen voltooien en de daartoe behoorende voorwerpen tevens te rangschikken. ${ }^{73}$

Friederich werd door dit voorstel, dat direct werd aangenomen, opnieuw aan het genootschap verbonden met een belangrijke taak. Hij liet op 20 maart weten de opdracht 'volgaarne' te willen aannemen, maar eerst een reactie te willen afwachten van de gouverneur-generaal, in wiens opdracht hij de inscriptie-verzameling aanlegde. ${ }^{74}$ In mei van dat zelfde jaar bleek uit een rapportage van sergeant N.W. Hoepermans, een van de militairen die Friederich bij zijn inscriptie-opdracht ter zijde stonden, dat er al tweehonderdtwintig stenen en achthonderd bronzen waren beschreven en gerangschikt. Hoepermans was van 1 april tot 21 mei 1868 in het museum werkzaam en de ordening was mogelijk geheel van zijn hand. ${ }^{75}$

\footnotetext{
71 ANRI KBG Dir 0997, citaat uit het antwoord van het genootschap, 4-3-1869 nr 24.

72 Notulen 6:86, vergadering 1-12-1868; 7:16, vergadering 4-3-1869.

73 Notulen 6:10. De brief aan Friederich van dezelfde datum in ANRI KBG Dir 0997, uitgaande brieven $1868 \mathrm{nr} 9$.

$74 \quad$ Notulen 6:24, brief van Friederich van 20-3-1868.

75 Friederich vroeg op 13-6-1868 vanuit Buitenzorg aan het genootschap een verklaring dat Hoepermans tussen 1-4 en 21-5-1868 werkzaam was geweest 'aan het Archeologisch Museum van het Bataviaasch Genootschap (ANRI KBG Dir 0998). Tijdens de vergadering van 26-5-
} 
Op het werk dat Van Hoëvell en Friederich al in de jaren 1840 aan de verzameling hadden verricht, werd voortgebouwd. Van de ruim honderdzeventig voorwerpen, beschreven op een collectie van circa vierhonderd in 1850, naar de meer dan duizend die Hoepermans in mei 1868 meldde, was een enorme vooruitgang. Drie bronzen werden als vermist opgegeven. Friederich antwoordde op 13 juni 1868 op een vraag van het bestuur of hij zich iets wist te herinneren van de vermissingen. Hij verwees naar wat er twintig jaar eerder was gepasseerd rond vermiste bronzen en handschriften. Van Hoëvell zou de zestienarmige Brahma (nummer 59 van de catalogus) mee naar huis hebben genomen. Ook voor een vermiste beker met tekens van de dierenriem en voor twintig Maleise manuscripten wees Friederich beschuldigend naar Van Hoëvell, maar de vermiste Shiva en Boeddha (nummers 23 en 90 van de catalogus) waren volgens hem na Van Hoëvells vertrek nog aanwezig geweest. De notulen noemen geen namen, al kan het niet anders of de naam van Van Hoëvell moet in de vergadering gevallen zijn. Het bestuur liet de zaak liever rusten. Een omstandig rapport over de oudheidkundige verzameling, dat Friederich in het vooruitzicht stelde, was op dat moment belangrijker. ${ }^{76}$

Hoepermans was degene die het werk deed. Het is de vraag of Friederich zich überhaupt in het museum liet zien. Hoepermans was begonnen als tekenaar en opmeter, opgeleid in Leiden in het maken van afdrukken van inscripties. Hij had zich in de loop van de meer dan vijf jaar waarin hij in Friederichs kielzog werkzaam was geweest, opgewerkt tot een deskundige. Hij was degene die de lijsten van de verzameling, het basiswerk voor de catalogus, had opgesteld, die begin 1869, 'sedert geruimen tijd bij zijn chef Dr R.H.Th. Friederich in behandeling' waren. ${ }^{77}$ De analogie met de in 1845 door Van Hoëvell uit het genie-depot geplukte Friederich, die zich daarna tot wetenschappelijk ambtenaar had opgewerkt, dringt zich op, vooral als men leest dat het Hoepermans was die in april 1869 de catalogus van de archeologische verzameling indiende. Hij stuurde tevens drie archeologische opstellen in. De assistent had de plaats van de meester ingenomen (Notulen 7:2).

Terwijl het genootschap nog hoopte dat Friederichs bewerking van de lijst van Hoepermans iets zou opleveren dat op een catalogus zou lijken, besloot het gouvernement tot Friederichs ontslag. Aandringen op het afronden van de catalogus, zoals het bestuur in januari en maart 1869 deed, had geen zin

\footnotetext{
1868 werd Hoepermans' brief van 17-5-1868 besproken. Daarin werden de aantallen beelden genoemd, alsook de vermissingen gemeld. Notulen 6:48-9.

76 Notulen 6:63, brief van Friederich van 13-6-1868. De originele brief is te vinden in de bundel correspondentie over de jaren 1867-1868 (ANRI KBG Dir 0998). Over de collectie Van Hoëvell recentelijk: Legêne 2005.

77 Notulen 7:8, vergadering 5-1-1869, brief van Hoepermans van 25-12-1868.
} 
meer. ${ }^{78}$ Het ontslag doorkruiste alle hoop op een bijdrage van Friederich. Het gouvernement stond de papieren en goederen van Friederich en Hoepermans aan het genootschap af, die er een commissie van drie personen op afstuurde. Het bestuur bleef zitten met een catalogus waarvan het driemanschap, de bestuursleden J.J. van Limburg Brouwer, Stortenbeker en Cohen Stuart, oordeelde dat die 'eene algeheele omwerking' diende te ondergaan. Hoepermans zou gepolst kunnen worden om te zien of hij daar, op aanwijzingen van de directeur van het museum, Levyssohn Norman, toe bereid was, echter niet dan nadat het gouvernement eerst over de toekomst van de sergeant-zonderbaas had besloten. ${ }^{79}$ De slotsom voor het genootschap was somber. Het had geen gedrukte catalogus, wel in handschrift de aanzet tot een catalogus. Het had een zeventigtal afdrukken van verspreide inscripties, maar geen persoon die deze collectie kon publiceren. Een stapel papieren en aantekeningen, aanzetten tot artikelen en studies, maar slechts een paar publicabele artikelen, twee van Friederich (1870 en 1875) en een van Hoepermans (1874, TBG 19, 21 en 23; Krom 1923, I:18). Friederich ging terug naar Nederland, Hoepermans maakte de catalogus niet af. Levyssohn Norman had wel een ingedeelde, genummerde en gerubriceerde archeologische collectie. Een van de commissieleden, Van Limburg Brouwer, zette later het werk aan de catalogus voort. In 1874 werd hem gevraagd hoe het daarmee stond, waarop hij vanuit Fort de Kock antwoordde dat hij het onmogelijk kon voltooien zonder eerst enige tijd in Batavia te verblijven (Notulen 12:11, 35). Pas in 1877 werd, zoals reeds vermeld, het werk aan de catalogus afgemaakt door Groeneveldt, al duurde het nog tien jaar voordat de oudheidkundigen die in handen konden nemen (Groeneveldt 1887). Dat de collectie toen bestond uit 2024 voorwerpen, waarvan 1856 in steen en metaal, waaronder 639 beelden, geeft aan dat de aanwinsten sinds 1850 de collectie hadden doen vervijfvoudigen.

Verzamelingen: etnologische voorwerpen

Zoveel als er te doen was over de catalogus van Friederich en Hoepermans, die in gewijzigde vorm pas in 1887 verscheen, zo weinig is er te vertellen over de voorgeschiedenis van de catalogus van de etnologische afdeling, die al in 1868 beschikbaar kwam en die de bezoeker van het nieuwe museum direct van dienst kon zijn. Bij het vertrek van Netscher naar Riouw in mei 1861 had Der Kinderen zowel de secretarisplaats bezet als de zorg voor het museum op zijn schouders genomen. ${ }^{80}$ Toen in juni 1862 bleek dat Der Kinderens drukke

78 Twee brieven van het bestuur aan Friederich, 5-1-1869 nr 8 en 4-3-1869 nr 23 in ANRI KBG Dir 0997.

79 Verslag van de commissie in Notulen 7:bijlagen $\mathrm{M}$ en $\mathrm{N}$.

80 TBG 11:432, vergadering 4-5-1861. 


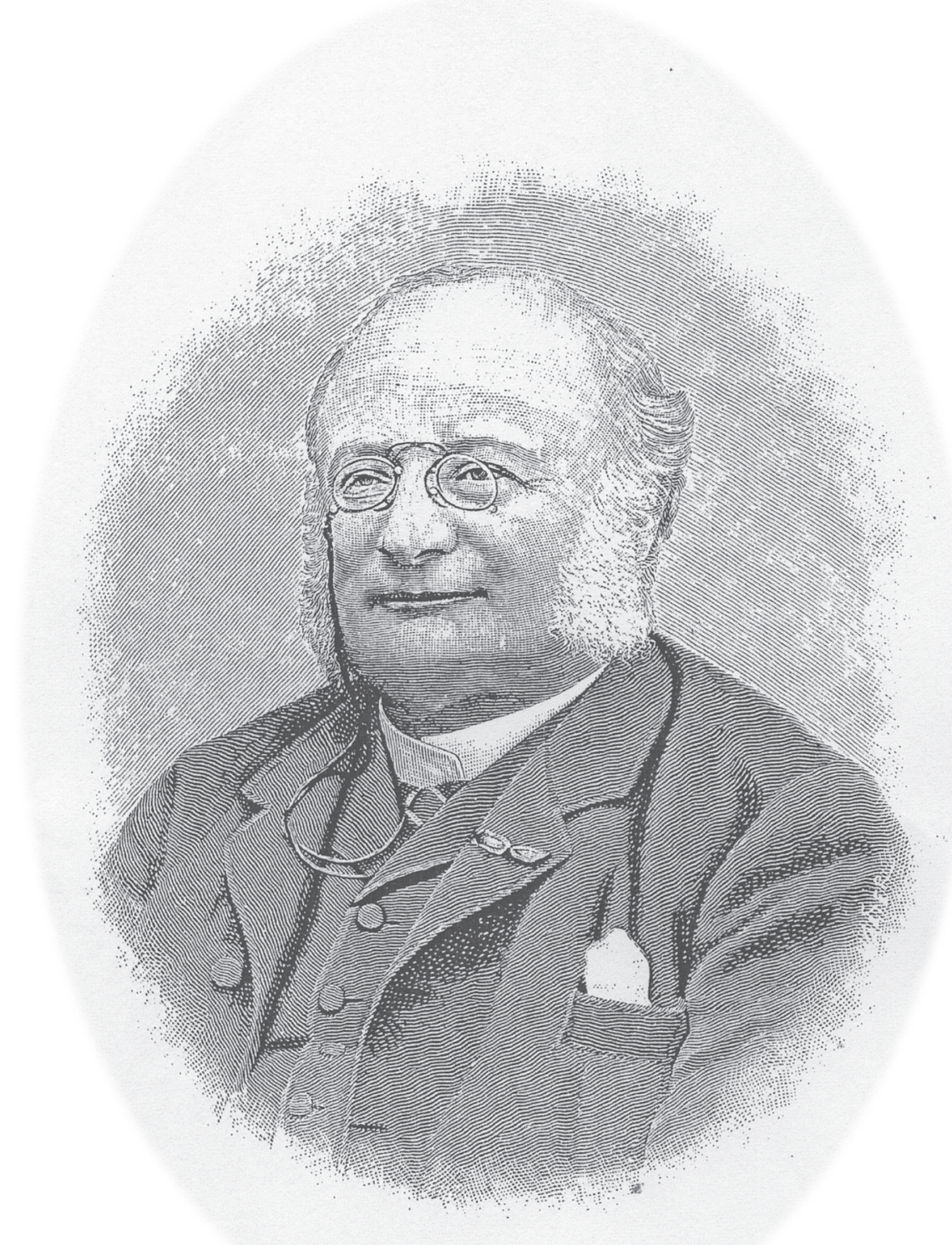

Portret van Henry David Levyssohn Norman, directeur van het museum en secretaris van het genootschap, lithografie uit Eigen Haard

(collectie RKD/Iconografisch Bureau Den Haag) 
ambtsbezigheden het hem onmogelijk maakten beide functies te blijven vervullen, was de plaats van directeur over de 'natuur- en kunstverzameling' van het genootschap overgenomen door de jeugdige referendaris bij de Algemene Secretarie, Henry David Levyssohn Norman (1836-1892) ${ }^{81}$

Levyssohn Norman was in Den Haag geboren. Hij studeerde rechten in Leiden, waar hij in 1857 promoveerde op een proefschrift over De Britsche heerschappij over Java en onderhoorigheden 1811-1816. Het jaar daarna slaagde hij tevens voor het Delftse examen voor Oost-Indisch ambtenaar, waarna hij nog vóór het einde van 1858 in Batavia arriveerde. Daar kwam hij te werken bij de Algemene Secretarie, waar hij in korte tijd opklom tot hoofdcommies en referendaris. Met hem trof het genootschap, dat hem in april 1862 tot bestuurslid had gekozen, het buitengewoon. De 25-jarige directeur had volgens het nieuwe reglement onder meer de zorg voor de catalogisering van de etnologische collectie tot taak. Dat vatte hij serieus op. In maart 1863 was het catalogiseerwerk zelfs al voor een groot deel klaar. De voorwerpen van de buitengewesten waren alle beschreven en de directie hoopte binnen een jaar de gedrukte catalogus te kunnen aanbieden. ${ }^{82} \mathrm{Nu}$ had Levyssohn Norman kunnen profiteren van voorwerk dat door Von Gaffron, Netscher en vooral Von Rosenberg was verricht. Von Rosenberg had in 1858 een indeling voor de catalogus gepresenteerd. In 1864 heette de etnologische catalogus van directeur Levyssohn Norman bijna voltooid. De publicatie werd nog opgehouden doordat de herkomst van sommige voorwerpen niet te achterhalen was. Ook hoopte de directie toen nog de catalogus van de mineralogische collectie aan het geheel te kunnen toevoegen (Notulen 2:136). In 1865 werd dat probleem in ieder geval opgelost, toen deze deelcollectie aan de Natuurkundige Vereeniging werd overgedragen. Toch zou het nog tot 1868 duren eer Levyssohn Normans catalogus zou verschijnen. ${ }^{83}$ Dat was echter, zoals al gezegd, een snelle sprong vooruit vergeleken bij de treurige gang die de catalogus van de oudheidkundige verzameling doormaakte. Dat Levyssohn Norman, inmiddels opgeklommen tot gouvernementssecretaris en secretaris van de Raad van Indië, zijn functie als directeur van het museum behield en in 1864 zelfs de post van secretaris van het genootschapsbestuur erbij nam, is een aanwijzing voor zijn bijzondere toewijding aan het genootschap. ${ }^{84}$ De Koninklijke Akademie te Amsterdam erkende zijn verdiensten

\footnotetext{
81 TBG 12:550, vergadering 7-6-1862. In 1862 was er weer niet van het 'museum' sprake.

TBG 1:161, vergadering 27-3-1863.

Notulen 3:67-9 over het afstoten van de mineralogische verzameling.

Over de bestuurswijziging van 6-8-1864, veroorzaakt door de benoeming van Van der Chijs tot inspecteur van het Indisch onderwijs, waardoor secretaris Mr. W. Stortenbeker de bibliothecarisplaats van Van der Chijs overnam en Levyssohn Norman de plek van Stortenbeker erbij nam, Notulen 2:214-5.
} 
door hem tot correspondent te benoemen. In mei 1869 legde hij zijn functie als directeur van het museum neer. Pas in oktober 1869, met zijn bevordering tot directeur van Binnenlands Bestuur in het vooruitzicht, verzocht hij het bestuur om een opvolger voor hem te zoeken als secretaris. Dat werd toen Van Limburg Brouwer, die hem in mei ook als directeur van het museum was opgevolgd. ${ }^{55}$ Levyssohn Norman werd later algemeen secretaris en beëindigde zijn Indische carrière als lid van de Raad van Indië (1877-1884). Zoals hij als genootschapssecretaris diende onder voorzitter A. Loudon, was hij als algemeen secretaris de rechterhand van diens broer, gouverneurgeneraal James Loudon. Het sympathieke levensbericht van de hand van zijn medebestuurslid, de latere directeur van de faktorij van de Nederlandsche Handelsmaatschappij, N.P. van den Berg, schetst een beeld van een zeer sociaal en bewogen man, die belang stelde in toneel en muziek (N.P. van den Berg 1895).

Als we de etnologische verzameling wat nader willen bekijken, zijn er naast de catalogus van 1868 natuurlijk ook weer de notulen. Afgaande op de meldingen in het register van Janssen, dat we overigens met voorzichtigheid moeten gebruiken, geldt voor de periode 1857-1866 dat de aandacht niet op Java geconcentreerd was. Anders dan bij de oudheidkundige verzameling, waar Java nu eenmaal een concentratie aan primaire bronnen bezat, was de etnologische aandacht juist naar buiten gericht. De aandacht ging in overgrote mate naar Sumatra, Borneo, Celebes en de kleinere eilanden. Dat komt overeen met de veranderingen die het gouvernement in de loop van het decennium 1850-1860 langzaam toeliet. Er kwam meer belangstelling voor de buitengewesten, waardoor verschillende gebieden binnen het aandachtsveld van militairen, bestuursambtenaren en zendelingen-missionarissen kwamen, meer dan in de periode tot 1850 het geval was geweest. Zo weerspiegelen de contacten met de wereld buiten Java, die het genootschap had, de veranderingen in de archipel, zelfs nog vóór de grote, op exploratie gerichte expedities van de jaren 1870. De Jong wijst in zijn Waaier van het fortuin op het geleidelijk binnen de Nederlandse invloedskring komen van Bangka, West-Borneo, Zuidoost-Sumatra en Ceram. Hij licht toe hoe in de tweede helft van de jaren vijftig Timor, Flores, de Molukken, Bone en Bandjermasin het doelwit werden, terwijl in de jaren 1860 Sumatra's Oostkust, Siak, de Lampongs en Deli binnen de Nederlandse invloedssfeer geraakten (De Jong 1998:233-41). Door de notulen en het Tijdschrift lopend, ziet men, net als in de collectie etnografica de aandacht van Java wegdrijven naar de hierboven genoemde gebieden.

85 Over H.D. Levyssohn Norman: ENI s.v. Levyssohn Norman. Over zijn aftreden als directeur van het museum, Notulen 7:33-4 (vergadering 4-5-1869) en als secretaris Notulen 7:51 (vergadering 5-10-1869). Op 18-12-1869 volgde zijn bevordering tot directeur van het Binnenlands Bestuur. 
In de Verhandelingen is deze verschuiving minder duidelijk, doordat er minder frequent delen verschenen en de grote monografieën voor een deel bibliografisch van aard waren, dan wel als catalogus fungeerden. De tekstedities waren vooral op het Javaans en het Chinees gericht.

Als we kijken naar het actieve verzamelbeleid, dan zien we dat nog steeds gegrepen werd naar het aloude middel van de circulaire, waarin leden en bestuursambtenaren gevraagd werd om voorwerpen te verzamelen en naar Batavia te zenden. In dat opzicht was er sinds 1779, toen de directie de eerste vragenlijst uitstuurde, niets veranderd. Toen Netscher in 1857 een oproep opstelde, had men, door de Javaanse en Maleise vertaling ervan in de krant te plaatsen, ook Indonesische inzenders proberen te bereiken. ${ }^{86}$ Een jaar later kwam naar aanleiding van een zeer geprezen monografie over de zuidelijke districten van het regentschap Tjiandjoer door controleur T.W. Hoogeveen, de gedachte op om opnieuw een circulaire te laten rondgaan, nu gericht op de controleurs, om soortgelijke arbeid uit te lokken voor 'de meest verschillende gedeelten van Java'. Het bestuur zag toen bezwaren, hoewel het van mening bleef dat de circulaire wel dé manier bleef om 'van tijd tot tijd de aandacht openbaar te vestigen op meerdere punten, tot de ethnologie, statistiek, archaeologie en linguistiek van den indischen archipel betrekking hebbende, waaromtrent de wetenschap gegevens of nader kennis verlangt' ${ }^{87}$ Daarop werd in september 1858 wel een circulaire opgesteld, waarin een aantal desiderata van het genootschap werd opgegeven. Naast precieze opgaven van oudheidkundige aard, vroeg het genootschap naar wapens, kledingstukken, versierselen, talismannen. Het gaf daarbij de gewesten op, waarvan de collectie aanvulling verdiende: 'Atjeh, Oostkust van Sumatra, Palembang, Lampongs, Bangka, Zuidelijk en Oostelijk Celebes, Menado, den ganschen Molukschen archipel, Nieuw Guinea, Timor, Bali, Lombok en verdere oostelijke eilanden'. ${ }^{88}$ Java behoefde kennelijk geen aandacht.

Een aanschrijving van het genootschap of een van het gouvernement, dat maakte nogal verschil, vooral voor de aangesproken hoofden van de verschillende gewesten, die in hun ambtsijver nu eenmaal meer letten op de verzoeken uit Buitenzorg dan op die afkomstig van een particuliere instelling als het Bataviaasch Genootschap. Van het gouvernementsbesluit van 24 mei 1862 waarin de hele opdracht aan Brumund lag besloten en waarin ook de etnologie aandacht kreeg, mocht meer worden verwacht. De hoofden van gewestelijk bestuur werden - naar de woorden van het gouvernementsbesluit - uitgenodigd 'om ten behoeve van het gouvernement, zoveel hun zulks

86 TBG 7:257, vergadering 18-5-1857.

87 TBG 8:104, vergadering 19-6-1858. Het lijkt goed mogelijk dat het alweer Netscher was die de zaak aankaartte.

88 TBG 8:293, vergadering 16-9-1858. 
mogelijk is, ethnographische verzamelingen te maken, met last om die aan het Bataviaasch Genootschap van Kunsten en Wetenschappen op te zenden'. ${ }^{89} \mathrm{Al}$ gauw bleek dat de aanschrijving eerder vragen had opgeroepen dan dat ze residenten aan het werk had gezet. Op een collectie voorwerpen uit Deli na, die door de altijd ijverige resident van Riouw, Netscher, was gestuurd, had het bestuur tevergeefs op inzendingen gewacht. Toen op initiatief van Der Kinderen op 4 september 1863 een herinnering aan de gewestelijke bestuurshoofden was uitgegaan, kwamen de reacties snel binnen, in oktober drie, in december nog eens zes andere (Notulen 1:298, 319).

Het ging niet om voorwerpen, want de (assistent-)residenten bleken met de aanschrijving van het gouvernement problemen te hebben gehad. Die was te vaag geweest dan dat zij ermee uit de voeten konden. De resident van de Lampongse districten, F.M.G. van Cattenburch, had het in zijn brief van 20 oktober 1863 kernachtig uitgedrukt. De zinssnede 'zooveel zulks mogelijks is' uit het gouvernementsbesluit had hem tot de slotsom doen komen dat het aanleggen van de etnologische verzameling kosteloos moest gebeuren. 'Welligt is het gouvernement in het denkbeeld, dat die verzameling, misschien met moeite, maar altijd zonder groote uitgaven te vorderen, te maken zou zijn' (Notulen 1:319). De Lampongse resident sneed aansluitend een stel relevante vragen aan: als het niet kosteloos hoefde, voor wiens rekening kon dan worden ingekocht, en wie zou de inkopen beoordelen? Kon het eenmaal aangekochte door het Bataviaasch Genootschap worden afgewezen? Hoe zat het dan met de gemaakte kosten? Ter illustratie lichtte hij toe dat er in de Lampongs veel van buiten werd aangevoerd, dat dus niet authentiek Lampongs was, en dat het oorspronkelijk Lampongse, zoals de hoofdtooien van jonge meisjes, kostbaar was. Het bestuur moest zich daarbij een bedrag tot $f 300$ voorstellen, terwijl oor-, hals- en armversieringen eveneens duur zouden uitvallen (Notulen 1:320-1).

Het bestuur begreep dat er iets moest gebeuren, wilde men nog enig profijt trekken van de gouvernementele aanschrijving over het verzamelen uit 1862. Het wilde bij nadere circulaire uitleg geven over wat men onder een etnologische verzameling verstond. Verder wilde het de regering een mededeling ontlokken over de kosten. Tenslotte wilde het bestuur het bezwaar van gebrek aan tijd, dat door sommigen was aangevoerd, opheffen door verzamelgebieden aan te geven waarop de ijverigen zich in eerste instantie zouden moeten richten. Zo kwam er een prioriteitenlijst die begon met inheemse wapens en daarna muziekinstrumenten, vervolgens kledingstukken en lijfsieraden, daarna landbouwgereedschappen en huisraad (Notulen 1:323). In februari 1864 moest het gouvernement toegeven dat het bij de aanschrijving 
van mei 1862 het probleem van de kosten, die het aanleggen van een verzameling etnografica met zich zou meebrengen, had onderschat.

De regering kan niet ontkennen, dat $\mathrm{Zij}$ bij het doen van bovenbedoelde uitnoodiging op eenige welwillendheid gerekend heeft; evenwel is $\mathrm{Zij}$ genegen om de voorwerpen, die niet anders dan tegen betaling te verkrijgen zijn voor de daarvoor gestelde prijzen over te nemen, in welk geval alsdan bepaalde voorstellen van UwEdG. tegemoet worden gezien. ${ }^{90}$

Het bestuur van het genootschap liet daarop op 15 april 1864 een circulaire uitgaan om de zaak van het verzamelen nog eens uit te leggen en aan te geven dat de prioriteit bij inheemse wapens zou komen te liggen. Daarop reageerde prompt in juni resident Van Cattenburch met de geruststellende mededeling dat hij begonnen was met het verzamelen en dat hij binnenkort drie soorten wapens zou aanbieden. ${ }^{91}$

Daarmee leek de zaak voor een ieder duidelijk geworden. Dat dacht Levyssohn Norman niet. Hij wees er tegen het einde van 1864 op dat er weinig reacties op de circulaire van 15 april waren binnengekomen en weet dat aan de omslachtige werkwijze die bij die circulaire was vastgesteld. De gewestelijke bestuurders moesten eerst een opgave doen van de wapens die zij wilden inzenden, met tekeningen plus een opgave van de kosten, waarna het genootschap zou aangeven welke daarvan daadwerkelijk konden worden aangekocht. Levyssohn Norman vond het een onpraktische werkwijze en dacht dat het beter helemaal aan de hoofden van bestuur kon worden overgelaten. ${ }^{92}$ Een collectie van bijna driehonderd voorwerpen uit de residentie Kadoe was de eerste inzending die na de circulaire van 15 april binnenkwam. De controleurs E.D. Levyssohn Norman, van Magelang en broer van de directeur van het museum, en W.L.H.A. de Harloff, van Prapak, hadden tot tevredenheid van hun eigen resident en het genootschapsbestuur niet alleen de verzameling bijeengebracht, maar ook een 'met zorg uitgewerkte catalogus' ervan meegestuurd. Deze was zo nuttig dat Cohen Stuart er nog de suggestie bij deed de namen van de voorwerpen ook in het Javaanse schrift in de catalogus op te nemen, naast de Latijnse karakters waarin ze waren opgenomen. ${ }^{93}$

Wapens waren al sinds 1859 een aandachtspunt geweest. In het vorige hoofdstuk werd al het besluit gememoreerd om wapens, kledingstukken en

\footnotetext{
90 Notulen 2:60, vergadering 12-3-1864. De circulaire aan de gewestelijke besturen waaruit geciteerd wordt, is van 8-2-1864 $\mathrm{nr} 274$.

91 Notulen 2:173-4, vergadering 11-6-1864.

92 Notulen 2:304, vergadering 5-11-1864.

93 Notulen 2:205, 257 en 303. De resident had in eerste instantie aangekondigd dat alle vier controleurs van zijn residentie doende waren (brief van 18-7-1864). Per brief van 19-10-1864 waren het er twee, die hun collectie bleken ingestuurd te hebben.
} 
andere voorwerpen, die als huldeblijk aan de vertegenwoordigers van het bestuur werden aangeboden vanwege hun historische waarde als een aparte afdeling aan de verzameling van het genootschap toe te voegen. ${ }^{94}$ Daarna was de maatregel gevolgd op grond waarvan bij expedities veroverde wapens in de genootschapsverzameling konden terechtkomen. ${ }^{95}$ Daarbij gevoegd kwam nu de aanschrijving over wapens, die op 15 april 1864 van het genootschap was uitgegaan. Tussen 1859 en 1866 zijn er al zo'n vijftigtal meldingen van binnengekomen wapens. Bij sommige van deze meldingen ging het om grotere groepen voorwerpen, zodat het al met al om honderden afzonderlijke exemplaren ging. De resident van Madoera, N.D. Lammers van Toorenburg, bracht het bestuur op het idee om contact te zoeken met kantoren van justitie en politie waar zich inheemse wapens zouden kunnen bevinden. Tegen deze manier om de verzameling uit te breiden had het gouvernement echter bezwaar (Notulen 2:187, 222).

Een ander specialisatiepunt in de collectie vormde een groep 'bewerktuigde wigvormige stenen' of wiggen, die binnen het belangstellingsgebied van het genootschap waren gekomen door een schenking van 86 van die stenen door A.W. Kinder de Camercq, bij diens vertrek naar Europa in 1862. De inzender wees erop dat de stenen bekend waren als 'batoe goentoer' (donderstenen) en beval nader onderzoek aan. Hij twijfelde er niet aan of zijn stenen, die in West- en Midden-Java waren opgegraven, behoorden tot een pre-hindoeïstische periode. Hij wees op hun gebruik als vuurstenen bij de bevolking. ${ }^{96}$ Hoewel de ouderdom van deze wiggen eerder een plaats in een prehistorische verzameling rechtvaardigde, is het begrijpelijk dat het actieve gebruik dat ervan werd gemaakt door de bevolking ze voorlopig in de etnologische collectie deden belanden. Het bestuur liet er geen gras over groeien en stuurde een circulaire om de leden op deze merkwaardige stenen te wijzen en inzendingen uit te lokken. ${ }^{97}$ Beschermheer Sloet betoonde zich weer een ijverig inzender. Hij stuurde eerst een Djokjase wigge en in december 1863 nog eens elf van die vuurstenen, pijlpunten en mesjes die in Ede (Gelderland) waren gevonden en die op verzoek van Sloet door de directeur van het Leidse Rijksmuseum van Oudheden waren gestuurd. Ze konden dan dienen voor de vergelijkende etnologie in Nederlands-Indië. Nog weer later stuurde de gouverneur-generaal een Overijsselse wigge, die van Sloets broer, B.W.A.E. baron Sloet tot Oldhuis, afkomstig was, met hetzelfde doel. ${ }^{98}$ De wiggencir-

TBG 9:9, 43, vergadering 6-11-1858 en 5-2-1859.

TBG 9:37, 42, vergadering 5-2-1859.

Notulen 1:48-9, vergadering 22-11-1862.

Notulen 1:153. De circulaire was van 1-1-1863.

Notulen 1:153 (voor de Djokjase wigge), 308 (voor de Edese) en Notulen 2:236 voor de Overijsselse. 
culaire had een positief effect. Vóór het eind van 1864 waren er nog eens acht andere inzendingen en bleek de collectie sinds de schenking door Kinder de Camercq verdubbeld. ${ }^{99}$ Op zijn beurt zorgde het bestuur er weer voor dat de Britse arts J. Barnard Davis uit Shelton een tiental Javase donderstenen ontving voor diens vergelijkend onderzoek. ${ }^{100}$

Was de circulaire voor de etnologische verzameling een belangrijk hulpmiddel, het bestuur vatte de zaken ook gerichter aan door onderzoekers persoonlijk aan te schrijven en hen om medewerking te verzoeken. Deze werkwijze had in 1856 van de exploratiereis naar Nieuw-Guinea 'een gansch museum' opgeleverd van voorwerpen van dat eiland (TBG 12:175-6). A. Bernstein, die in oktober 1860 tot lid was benoemd, omdat zijn ornithologisch onderzoek in de Grote Oost hem op zijn reizen in de gelegenheid zou stellen de belangen van het genootschap te behartigen, kreeg in juni 1862 een herinnering aan het verzoek om medewerking met de vraag op te geven wat hij er tot dan aan gedaan had. ${ }^{101}$ Toen hij daarop van zijn reis naar de Molukken en Nieuw-Guinea verslag deed, was dit nogal ontmoedigend. Hij had zo goed als niets voor het genootschap kunnen bemachtigen. Zijn vermelding echter van bepaalde doodsbeenkisten van de Tabellorezen en van Alfoerse schilden maakte het bestuur nieuwsgierig. De vermelding dat hij op reis zou gaan naar Halmaheira leidde tot het besluit hem $f 300$ toe te zenden met het verzoek zo'n Tabellorese doodsbeenkist en een collectie Alfoerse schilden aan te schaffen, alsook andere voorwerpen die hij op zijn reizen nog mocht tegenkomen. ${ }^{102}$ Verder werd de bioloog-geoloog-cartograaf Von Rosenberg in 1862 door het gouvernement als ambtenaar 'speciaal belast met het doen van reizen in het belang van natuurkundige onderzoekingen'. ${ }^{103}$ Het bestuur verzocht hem op zijn reis naar de Tanimbar-eilanden de belangen van het genootschap indachtig te zijn (Notulen 1:151-2). Von Rosenberg had echter lucht gekregen van de gunstige aanbieding van $f 300$ aan Bernstein, die hem het aankopen van voorwerpen gemakkelijker zou maken en vroeg dus bij het gouvernement of hij niet op dezelfde wijze kon worden behandeld. Bernstein bleek indertijd echter het geld weer te hebben teruggestuurd, omdat hij bereid was kosteloos voorwerpen aan het genootschap af te staan. Zo was de $f 300$ weer terug en kon nu voor Von Rosenberg worden gebruikt. ${ }^{104}$ In oktober 1864 greep het gouvernement, dat kennelijk uit het geval van Bernstein de lucht

\footnotetext{
99 De meldingen zijn toegankelijk via het Register op de Notulen over de jaren 1857-1866, Janssen 1867:29.

100 Notulen 3:107, vergadering 7-7-1865.

101 TBG 10:464, vergadering 6-10-1860; Notulen 12:567, vergadering 7-6- 1862.

102 Notulen 1:87-90, brief van 18-12-1862.

103 Over Rosenberg ENI (s.v. Rosenberg), waar ook het citaat uit afkomstig is. Verder Bakels en De Jonge 2001:11.

104 Notulen 2:223-4, vergadering 16-9-1864.
} 
van 'bijklussen' had gekregen, in en bracht onder Von Rosenbergs aandacht dat de door hem verzamelde etnologische voorwerpen eigendom waren van het gouvernement en dat hij dubbelen moest afstaan aan het museum van het genootschap. Tegelijkertijd liet het gouvernement Von Rosenberg weten dat het genootschap bereid was etnologische voorwerpen die hij zou verwerven, te bekostigen. ${ }^{105}$ Van al dit gekrakeel werd het museum uiteindelijk niet veel wijzer. Bernstein schonk in 1864 een aantal Halmaheirase voorwerpen, en zag daarbij fijntjes af van de mogelijkheid om een beroep te doen op gelden. ${ }^{106}$ Daarbij waren Alfoerse schilden, waarover eerder was gecorrespondeerd. Von Rosenberg droeg in 1864 een verzameling voorwerpen uit de residentie Menado en in 1866 een verzameling voorwerpen van de Aroe-eilanden bij. ${ }^{107}$ Vooral de Leidse collecties profiteerden van Von Rosenbergs reizen.

In tegenstelling tot de gouvernementele reizigers en natuuronderzoekers Von Rosenberg en Bernstein, die nogal wat over en weer correspondeerden eer het genootschap ook werkelijk voorwerpen van hen ontving, was de controleur van Tondano, later assistent-resident van Gorontalo, Johann Gerard Friedrich Riedel een ambtenaar die met de geringste aansporing van het genootschap activiteiten aan de dag legde, voor zowel het Tijdschrift als het museum. Riedel was in 1832 geboren in Tondano en was na een opleiding in Nederland in 1853 als ambtenaar naar Indië gekomen. Eenmaal terug in zijn geboortestreek legde hij zich toe op de taal en op de gebruiken van de Minahasa. Hij betekende veel voor de ontwikkeling van de handel in Gorontalo. De Minahasa was het genootschap niet onbekend, want de resident van Menado, A.J.F. Jansen, had in de jaren vijftig een tweetal artikelen over talen en dialecten en over de landbouw in de Minahasa aan het Tijdschrift bijgedragen. In 1862 was een rapport van de commissaris voor de residentie Menado, K.H. Tutein Nolthenius over verenigingen in de Minahasa ter beschikking gekomen en Van der Chijs, altijd alert, had gewezen op de mogelijkheid om informatie over de Alfoeren bij Riedel in te winnen (Notulen 1:32, 215). Deze reageerde daar in 1863 op met een artikel onder de titel 'Iets omtrent het landschap Bolaäng Mongondouw'. In hetzelfde jaar stuurde hij voor het eerst een verzameling voorwerpen uit Gorontalo, waaronder donderstenen die ter plaatse als amuletten werden gebruikt, gevolgd door een in 1864 via de resident van Menado aangeboden grotere verzameling van voorwerpen van de Tooen-oen Boeloe-stam. ${ }^{108}$ Hij stuurde ook een opstel over de stenen graven in de Minahasa mee en vermeldde dat

105 Notulen 2:242-3, brieven van 29-10-1864, waarvan het genootschap afschriften ontving.

106 Notulen 2:71-2, vergadering 12-3-1864.

107 Notulen 2:38, vergadering 9-2-1864; 4:95-6, vergadering 27-3-1866.

108 Notulen 2:36, brieven van Riedel van 23 en 26-12-1863; Notulen 2:81 en volgende een catalogus van de in april 1864 aangekomen voorwerpen. 
hij zich onledig hield met de vergelijkende taalstudie en al in zes streektalen boekjes had vervaardigd. Die durfde hij niet aan te bieden aan het gouvernement omdat de gouvernementsbesluiten over bekronen en drukken van leerboekjes in inheemse talen alleen over het Javaans, Maleis en Soendanees spraken. Riedel had daaruit afgeleid dat er geen beleid was, gericht op het stimuleren van andere streektalen. Mede door zijn aandacht voor de stenen graven (tiewoekar) kwam het genootschap in het bezit van zo'n grafsteen (Notulen 3:86). In 1864 stuurde Riedel twee beeldjes, een opstel over een ordalium, een soort godsgericht, en een grote verzameling voorwerpen uit vier verschillende landschappen van de Minahasa (Notulen 2:165, 170, 233). In 1866 opnieuw artikelen voor zowel het Tijdschrift als voor de Verhandelingen, als ook voorwerpen voor het museum (Notulen 4:31, 180, 251). Riedel was in alle opzichten het ideale, actieve lid voor het genootschap. Zowel taalkundige studies als historisch-etnologische opstellen vloeiden uit zijn pen. Hij was een systematisch verzamelaar en - geboortig uit de streek - precies de regiovertegenwoordiger, die het genootschap idealiter zich in andere streken ook zou wensen. De verzameling etnografische voorwerpen uit de Minahasa van het museum groeide dan ook aanzienlijk dankzij Riedel. Zijn overplaatsing naar Billiton, waar hij assistent-resident werd, was in zekere zin een verlies. In juni 1871 werd Riedel tot erelid benoemd. ${ }^{109} \mathrm{Hij}$ werd resident in Timor en later in Ambon en bleef na zijn pensionering in Indië wonen. Hij stierf in 1911 in Batavia (ENI s.v. Riedel).

Een bijzondere collectie in het museum vormde de verzameling rijkssieraden van de sultan van Bandjarmasin. De opvolgingsperikelen aan het Bandjarmasinse hof hadden vanaf 1852 tot problemen met het koloniale bestuur geleid, die uiteindelijk voerden tot de ondergang van dat rijk. In 1860 lijfde het gouvernement het grondgebied van Bandjarmasin in en verloren de rijkssieraden, symbolen van de waardigheid van de sultan, die in de laatste jaren in feite de leenman was geweest van het gouvernement, in de ogen van het koloniale bestuur hun betekenis. Ze werden hem afgepakt - het gouvernement sprak van 'afpakking' - en naar Batavia overgebracht. ${ }^{110} \mathrm{De}$ 'procesverbalen van afpakking' werden in juli 1861 door het gouvernement aan het genootschap gestuurd met het aanbod om daaruit voor het museum 'zoodanige voorwerpen te kiezen, welke uit een archeologisch oogpunt als zeldzaamheden dienden te worden bewaard'. Hoewel de eerste gouvernementssecretaris het archeologische belang in zijn brief als motief aanduidde, was er eerder sprake van een historisch-etnologisch belang. Het genootschap mocht vrijelijk kiezen. Alleen de in de collectie begrepen zeventig karaats

110 Zie een samenvatting van de Bandjarmasinse krijg in ENI 1:135-6. 
diamant wilde het gouvernement behouden. ${ }^{111}$ De commissie uit het bestuur, die met de lange lijst gewapend de voorwerpen in de provisiepakhuizen ging bekijken, kwam tot de conclusie dat de collectie bijeen moest blijven en dat het genootschap die in haar geheel wilde overnemen. Daarin bewilligde het gouvernement en zo kwam het genootschap na de bezittingen van de afgezette Bantamse sultan in het bezit van die van de Bandjarmasinse. ${ }^{112}$ In 1862 kwamen daar nog wapens bij van een van de hoofdpersonen in de voortgaande perikelen, prins Hidajat-Oelah, die op grond van de bepaling van 1858 over de plaatsing in het museum van buitgemaakte wapens, werden overgedragen. ${ }^{113}$ Ook in 1863 kwamen er nog krissen en met diamanten bezette sieraden binnen (Notulen 1:193, 220, 283). Dit bezit was echter niet altijd definitief. In 1864 kreeg een van de belanghebbenden in de strijd om de troon, sultan Tamdjid Illah, zijn zwaard Parang Sondrek, weer terug. ${ }^{114}$ Het omstreden bezit was in handen van sommigen een pijnlijke zaak. In 1865 deed de resident van de Zuid- en Ooster-afdeling van Borneo, kolonel E.C.F. Happé, afstand van het recht om een Bandjarmasinse kris en een lans tot het einde van zijn leven in bezit te houden, een recht dat hem bij koninklijke machtiging als een beloning voor bewezen diensten was verleend. Bij nader inzien bezwaarde het bezit Happé, zodat hij er van afzag en de twee wapens alsnog aan de collectie in het museum werden toegevoegd. Dat gebeurde ook met twee andere wapens die in hetzelfde jaar in de nalatenschap van de overleden regent van Martapoera werden aangetroffen en waarop de regent noch zijn nakomelingen, naar de mening van het gouvernement, aanspraak konden maken. Die wapens gingen eveneens naar Batavia. ${ }^{115}$ Hetzelfde zou in 1865 nog eens gebeuren met een kris en twee houten beelden. De collectie Bandjarmasinse kroongoederen groeide daardoor steeds verder aan (Notulen 3:91, 130).

Op dezelfde manier als aan de Bandjarmasinse collectie voorwerpen werden toegevoegd, gebeurde dat in 1865 met enkele goederen van de afgezette sultan van Bantam, die al tientallen jaren in het museum waren. Een met spiegels bekleed ledikant, een kistje met handschriften dat onder dat ledikant werd bewaard, een lans met een vlag en vijftien metalen bekkens gingen over van de regent van Serang naar de collectie Bantamse goederen in het museum. ${ }^{116}$ De rijkssieraden van Bone ondergingen niet hetzelfde lot.

111 De diamant zou later in Nederland op 38 karaats worden gesteld en leverde bij een veiling in $1898 f 5.620$ op, veel minder dan men gedacht had (Fasseur 1995:109-11).

112 TBG 12:122, vergadering 13-7-1861; 12:136, vergadering 13-7-1861; 12:219, vergadering 14-12-1861.

113 Notulen 1:33, vergadering 11-10-1862.

114 Notulen 2:174, vergadering 11-6-1864.

115 Notulen 3:79, vergadering 11-5-1865.

116 Notulen 3:130-1, vergadering 19-9-1865. 
Zij gingen niet over naar het Bataviaasch Genootschap, al mocht dat er wel de beschrijving van hebben en afbeeldingen publiceren (TBG 10:317, 448; Notulen 1:301).

De etnologische afdeling groeide aldus op verschillende manieren aan. Waar de oudheidkundige collectie op Java geconcentreerd was, richtte de etnologische zich juist op de andere eilanden, waar nog zoveel te ontdekken was, letterlijk door ontdekkingsreizigers. Ook oorlogsbuit speelde hier meer dan op Java, waar met het einde van de Java-oorlog (1830) geen nieuwe vijandelijkheden tegen de vorsten meer waren ondernomen. Toch bleek de verzameling bij de presentatie van de catalogus in 1868 Javaanser van kleur dan men uit het voorgaande zou verwachten. De grote collectie van de controleurs Levyssohn Norman en De Harloff, die bovendien zelf voor goede documentatie hadden gezorgd, nam meer dan een kwart van de catalogus in beslag. Van Sumatra waren de Westkust en de Lampongs het best vertegenwoordigd. Onder West-Java werden de Bantamse rijkssieraden opgenomen. Onder de Zuid-Ooster-Afdeling van Borneo de Bandjarmasinse rijkssieraden. Bali en Lombok waren slecht vertegenwoordigd, dit ondanks de arbeid die Friederich in de jaren 1840 had ondernomen. Museumdirecteur Levyssohn Norman had in zijn heel korte verantwoording op verschillende problemen gewezen. Zo had hij hulp ingeroepen van Indonesiërs die in Batavia waren om bepaalde objecten te kunnen thuisbrengen, waarbij hem meermalen tegenstrijdige informatie was gegeven. Vandaar dat de catalogus, die in het museum klaarlag, was doorschoten met wit papier, opdat bezoekers correcties en aanvullingen kwijt konden. ${ }^{117}$

\section{Publicaties: Indische taalkunde}

De bevordering van de studie van de inheemse talen bleef een voorname doelstelling van het genootschap. In de jaarverslagen die tussen 1863 en 1866 verschenen, werd dat onderwerp steeds als eerste behandeld, vóór de berichten over oudheidkunde en etnologie, en vóór het nieuws over de publicaties van het genootschap. Onder het kopje 'Indische Taalkunde' kwamen verschillende aspecten aan de orde: het werk aan woordenboeken en spraakkunsten van talen van de archipel, vergelijkend taalonderzoek, tekstedities, school- en leesboeken in de inheemse talen voor onderwijs en volksontwikkeling en tenslotte het verzamelen van handschriften en inscripties voor het museum.

Kijken we naar de publicaties, de Verhandelingen voorop, dan is voor

117 Inleiding van twee pagina's door Levyssohn Norman in Katalogus ethnologische afdeeling 1868. 
taalkunde, in deze ruime zin opgevat, veruit de meeste plaats ingeruimd. In de delen 29-33 (1862-1868) werd de helft van de beschikbare pagina's aan de Indische taalkunde besteed. Het Soendanese woordenboek van Jonathan Rigg springt daarin naar voren, maar ook Von Dewalls studie naar vormveranderingen in het Maleis. Als we de periode iets ruimer nemen, de delen 27-35 (1860-1870), dan domineren de tekstedities boven de strikt taalkundige disciplines: de Brata-Joeda (27-28), de Lajang Damar Woelan (30), de Hsi Yuan Lu (30, vertaling), de Hoa Tsien Ki (32, vertaling) en de Ardjoena-sasra-baoe (34). De Verhandelingen waren in die jaren verder gewijd aan etnologie (Nias en de Chinese bevolkingsgroep), de oudheden (Brumunds studie), de numismatiek (Netschers en Van der Chijs' Munten van Nederlandsch-Indië) en geschiedenis (Netscher over Djohor en Siak). ${ }^{118}$ Met de nadruk op taalkunde, inclusief tekstedities, werd aldus de lijn van de jaren 1840 en 1850 doorgetrokken. Overigens was het genootschap in de periode 1860-1870 met negen delen Verhandelingen zeer productief.

In het Tijdschrift was de taalkunde veel minder prominent aanwezig. Daar domineren de etnologische studies, reisbeschrijvingen en geschiedenis. Daar geldt bovendien, in afwijking van de Verhandelingen die nogal op Java gericht waren, een gerichtheid op de buitengewesten. We kunnen dus zeggen dat de Verhandelingen in deze jaren vooral aan de taalkunde-in-ruime-zin plaats boden, terwijl het Tijdschrift de land- en volkenkunde voor zijn rekening nam.

Riggs Soendanese woordenboek was de enige lexicografische bijdrage, een vakgebied dat er trouwens in het algemeen bekaaid afkwam. In de jaren 1840 was nog er een woordenboek van het Favorlangs (van Formosa) verschenen en een aparte Formosaanse woordenlijst. Een lexicografische traditie was er nauwelijks binnen de publicaties. Woordenboeken kwamen echter wel ter sprake, al leidde het niet vaak tot publiceren. Riggs woordenboek had lang moeten wachten. Friederich had er vele editeursuren aan besteed, maar het kon de Soenda-kenner Daniël Koorders niet bekoren. Hij besprak het woordenboek nogal streng in de Java-Bode. Overigens nam het bestuur dit goed op. Koorders' commentaar kon de wetenschap alleen maar vooruit helpen (Notulen 1:133-4). Van het Javaanse woordenboek waar C.F. Winter en J.A. Wilkens sinds 1844 in opdracht van het gouvernement aan werkten, kon in 1865 het manuscript van de eerste letters in Batavia worden bekeken. Het bestuur wilde zich met het gouvernement over de uitgave in afleveringen verstaan, maar Wilkens, die sinds de dood van Winter in 1859 het woordenboek verder alleen bewerkte, voelde daar niet voor. Het woordenboek zou

118 Tussen 1862-1868 waren de pagina's als volgt verdeeld: tekstedities 204, taalkunde in striktere zin 779, etnologie 348, numismatiek 230, oudheidkunde 309, geschiedenis 81 . De delen uit 1860 en 1870 bevatten nog eens 1713 pagina's tekstedities. 
uiteindelijk nooit verschijnen, maar in manuscript in Leiden terecht komen en daar het materiaal vormen voor latere lexicografen (Notulen 2:103, 3:55). Een Kawi-Javaans woordenboek van L. Rhemrev, een Nias' woordenboek van A.H. Intveld (Notulen 1:138-9), een Alfoers woordenboek van J.S. van Coevorden (Notulen 2:107) en een Nederlands-Mafoors (Papoeaas) woordenboek van Geisler en Jaesrich (Notulen 4:154) kwamen wel ter sprake, maar raakten weer vergeten. Er werd dus wel aan woordenboeken gewerkt, maar ze werden niet afgemaakt of bleven buiten het zicht van het genootschap. Van der Tuuk zou hier als lexicograaf voor het Batak en het Kawi-Balinees torenhoog bovenuit steken, maar met hem had het genootschap in deze periode nauwelijks contact, omdat hij in Amsterdam zat. Zijn publicaties, te beginnen met die over het Lampongs, verschenen in het Tijdschrift pas tussen 1869 en 1884 (Groeneboer 2002:891-7).

De projecten van Karel Frederik Holle (1829-1896) kregen wel de nodige aandacht. Deze kleurrijke en aan het Soendanees toegewijde theeplanter had in 1857 voor het eerst over Soendanese poëzie geschreven in het tijdschrift van het genootschap (TBG 6:114). In maart 1859 stuurde hij 101 Soendanese spreekwoorden in, die eveneens in het tijdschrift terechtkwamen. ${ }^{119}$ Holle werd in 1860 lid van het genootschap. Vanuit Garoet benaderde hij het bestuur op 6 augustus 1862 met twee plannen op het gebied van de vergelijkende taalkunde: het samenstellen van een 'vergelijkende woordenlijst van alle in Nederl. Indië gesproken wordende inlandsche talen en dialecten' en een overzicht van 'alle in de Nederl. Indischen Archipel in gebruik of in gebruik geweest zijnde letterschriften' (Notulen 1:13-4). Voor de woordenlijst dacht het genootschap tweehonderd woorden nodig te hebben. Het werden er honderdvijftig, waarvan Holle de Soendanese vertaling vaststelde, waarna de lijst naar vijf taalkundigen ging. Men hoopte aldus een zestal talen of taalgroepen te bestrijken. ${ }^{120}$ Een jaar later kon men al tevreden toezien op inzendingen van vijftien talen en dialecten (Notulen 2:106). In 1865 besloot het bestuur voor het Javaans de diepte in te gaan. De inzending van W.Palmer van den Broek uit Soerakarta werd aan alle hoofden van gewestelijk bestuur op Java gezonden om te zien of het Javaans in hun gewest afweek van het Solose taaleigen (Notulen 3:55). Er was duidelijk enthousiasme over Holles project. Het bestuur werkte mee. De residenten van Java eveneens. In 1865 bleven inzendingen binnenkomen (Notulen 3:85, 100, 106, 133, 144, 151-2). Van der Chijs die met voorzitter A. Loudon in 1866 aanwezig was bij de opening van de kweekschool voor inheemse onderwijzers in Bandoeng, de eerste in

119 TBG 9:220, vergadering 9-4-1859. De spreekwoorden in TBG 10:62.

120 Notulen 1:139-40. Het ging om H. von DeWall (Maleis), W. Palmer van den Broek (Javaans), H.N. van der Tuuk (Bataks), B.F. Matthes (Boeginees, Makassaars, andere talen van Celebes) en J.G.F. Riedel (Alfoers en andere talen van de Minahasa). 
zijn fuctie van inspecteur van het inheemse onderwijs, de tweede als lid van de Raad van Indië, had op zich genomen om met Holle te confereren over de tot op dat moment binnengekomen lijsten. ${ }^{121}$ Holle was ook een drijvende kracht achter de oprichting van de Bandoengse kweekschool.

Zes jaar later moest Van der Chijs, inmiddels vice-voorzitter geworden, bekennen dat het gesprek met Holle in 1866 wel had plaatsgevonden, maar dat voorzitter Loudon, die inmiddels was overleden, aan de directie daarvan geen verslag had uitgebracht. ${ }^{122}$ Het rapport van Van der Chijs uit 1872 eindigde met een vraag: 'Welke is de tegenwoordige toestand dier zaak, waaraan indertijd te veel moeite en kosten zijn besteed om haar onafgedaan te laten?' Het project dat tussen 1862-1865 veel enthousiasme had opgewekt, was verzand. Dat was niet te wijten aan Holle die onvermoeibaar doorwerkte aan zijn projecten.

Het tweede, op het terrein van de historisch-vergelijkende taalwetenschap gelegen project, het overzicht van de Indische letterschriften, werd in 1877 door Holle in Buitenzorg uitgegeven op kosten van het Bataviaasch Genootschap, onder de titel: Tabel van oud- en nieuw-Indische alphabetten. Een uitgebreidere uitgave volgde in 1882. ${ }^{123}$ Van den Berges biografie van Holle besteedt terecht ruime aandacht aan Holles verdienste voor de paleografie van Indonesië, waaraan hij met zijn Tabel bijdroeg. Het was een belangrijk hulpmiddel voor iedereen die Indonesische inscripties of handschriften wilde lezen. Van den Berge oordeelde mild over het Bataviaasch Genootschap, terwijl dat het woordenlijstenproject van 1862 lelijk liet verzanden (Van den Berge 1998). Onvermoeibaar stelde Holle in 1880 aan het genootschap een nieuw, groter woordenlijstenproject voor dat pas in 1894 leidde tot de publicatie van een Blanco woordenlijst ten behoeve van taalvorschers in den Nederlandsch-Indischen archipel. Niet gehinderd door enige slechte herinnering aan het verzande project ging een hele nieuwe generatie aan de slag met wat terecht genoemd werd: Holles woordenlijst. Tussen 1895 en 1898 kwamen tientallen inzendingen binnen. Holle mocht dit niet meer beleven. Hij stierf in 1896 (Van den Berge 1998:187-8). Pas in 1980 zouden de lijsten door W.A.L. Stokhof worden gepubliceerd.

Overigens was het Van der Tuuk die naast Holle het belang van woordenlijsten inzag voor de vergelijkende taalstudie. Nadat hij in de Lampongse districten in opdracht van het gouvernement veldwerk had gedaan (1868-1869), verscheen van hem in het Tijdschrift een 'Proeve van een vergelijkende woordenlijst van de Lampongsche tongvallen', terwijl hij in die periode in verschil- 
lende brieven van zijn bevindingen over het Lampongs verslag deed. ${ }^{124}$ Ook schreef hij aan Holle, met wie hij voor zijn vertrek naar Sumatra in Garoet over diens woordenlijsten en alfabetten had gesproken. In 1872 deed Van der Tuuk nog eens een voorstel aan het genootschap om woordenlijsten rond te zenden in verband met het onderzoek naar de Sumatraanse talen (Notulen 10:150). Toen zat Van der Tuuk echter al op Bali en deed hij dit voorstel in verband met zijn eigen onderzoek naar het Kawi. De gang van zaken met Holles woordenlijst laat zien dat binnen het genootschap in de jaren 18621868 wel aanvankelijk enthousiasme werd opgebracht voor dit belangrijke project, maar dat een tekort aan mankracht en vakmanschap verhinderde het binnen redelijke tijd af te ronden.

Tot de taalkunde rekende het genootschap ook de adviserende taak die het in 1858 op verzoek van het gouvernement op zich had genomen om leer- en leesboekjes in het Javaans en Maleis voor het inheemse onderwijs te beoordelen om te zien of zij voor de uitgeloofde premies in aanmerking kwamen. ${ }^{125}$ Van dat oordeel hing af of het gouvernement tot het drukken van die boekjes bij de Landsdrukkerij overging. Tot 1868 werden aan het genootschap achtentwintig manuscripten ter beoordeling voorgelegd. De kampioenmededinger naar de premie van het gouvernement was de assistent-resident van Gorontalo, Riedel, van wie het genootschap vier inzendingen te beoordelen kreeg. Goede tweeden waren de predikant bij de inheemse gemeente te Depok en latere hoogleraar Maleis te Delft, J.R.P.F. Gonggrijp, verder de Semarangse zendeling, later onderwijzer en lector Maleis te Leiden, H.C. Klinkert en tenslotte de klerk-commies A.A. Voorneman. De enige genootschapsman die meedeed, was Netscher, van wie twee keer een inzending beoordeeld werd. Toen hij echter naar Riouw vertrok als resident, was hij niet meer in een positie om naar deze prijzen mee te dingen. Slechts twee van de te beoordelen inzendingen waren van Indonesiërs: Raden Bagoes Moedjarad uit Soerakarta en Raden Moehamed Hoesein, de hoofd-panghoeloe van Krawang. Het merendeel van de boekjes was in het Maleis.

De goede bedoelingen van het gouvernement en de positieve beoordeling die het genootschap over sommige werkjes gaf, konden niet voorkomen dat het project in een slecht licht kwam te staan door het oordeel dat Klinkert, zelf inmiddels als bijbelvertaler in dienst van het Nederlandsch Bijbelgenootschap getreden en in Riouw woonachtig, erover velde in de Bijdragen van het Koninklijk Instituut (1866) en de bijval, die hij daarop kreeg van Van der Tuuk in De Gids (1866). 'Dat gemors van Europeanen in de inlandsche talen, wan-

124 Groeneboer 2002:22-4 en briefnummers 191, 195, 196, 198, 199, 200, 202. Publicaties van Van der Tuuk in TBG vermeld in Groeneboers 'Lijst van publicaties Van der Tuuk', nrs 1869, 1870a en 1872a.

125 TBG 8:102, vergadering 19 juli - lees juni - 1858. 
neer zal men toch ten onzent inzien, dat het ons zoogenaamd moreel overwigt in de waagschaal stelt?', aldus collega bijbelvertaler Van der Tuuk over de beoordeling door Klinkert (Groeneboer 2002:533). Indirect kregen ook de beoordelaars van het genootschap een veeg uit de pan. Zij hadden immers, om verschillende redenen en met kracht van argumenten, over sommige van de door Klinkert bekritiseerde boekjes uitspraken gedaan, waarna het gouvernement had besloten tot de uitgave ervan. In de notulen kon iedereen nazien dat het vooral om Netscher ging, maar ook om Friederich, voorzitter Wassink, Brumund, Van der Chijs en Levyssohn Norman, die als beoordelaren namens het genootschap optraden. Aan de hoge taalvaardigheidseisen van Klinkert en Van der Tuuk voldeden deze bestuursleden niet. ${ }^{126}$ Ook Cohen Stuart was een 'vijand van al zulke boeken en boekjes voor schoolgebruik, welke in stede van beschaving te bevorderen, taalbederf in de hand werken, of wegens volslagen onverstaanbaarheid zonder eenigen invloed blijven' (Kern 1877:8).

Van der Tuuk zou in 1872 het genootschap adviseren de rapporten die het aan het gouvernement uitbracht over schoolboekjes openbaar te maken. Dat vond het genootschap te riskant en dus werd besloten het niet te doen. ${ }^{127}$ Wel had het genootschap al jaren eerder besloten zich in te zetten voor een betere verspreiding van de leesboekjes. Het gaf de gouverneur-generaal op 1 oktober 1862 in overweging 'de voor de inlanders ter landsdrukkerij uitgegeven wordende boekwerkjes meer algemeen en overal in de binnenlanden verkrijgbaar te doen stellen'. Op 23 maart 1863 besloot het gouvernement dit in ieder geval voor Java en Madoera te doen en met de verkoop de onderwijzers van de inheemse scholen, de zoutverkooppakhuismeesters en de koffiepakhuismeesters te belasten, die dan tien procent van de opbrengst zouden ontvangen. Verder moesten de residenten erop letten of er voldoende voorraad was (Notulen 1:137-8). Het succes dat Holle behaald had met de verkoop van Soendanees leesmateriaal was de aanleiding geweest tot het ongevraagde advies aan het gouvernement.

Ging het bij Klinkert, Van der Tuuk en Cohen Stuart vooral om het taalkundig falen van de vertalers, een heel andere kwestie was de inhoud van sommige schoolboekjes, die eveneens in het geding kwam. In 1858, bij een van de eerste adviezen, deed dit probleem zich al voor naar aanleiding van een boekje van Gibson. Omdat het 'van meer zuiver godsdienstigen aard'

126 Zie de beoordelingen in de notulen van de boekjes van R. Bagoes Moedjarad TBG 9:438 en TBG 10:15; van Voorneman TBG 10:308, 454 en TBG 11:402; van Martens TBG 10:312, 314, 446, 454 en TBG 11:413; van Gonggrijp TBG 11:420, 423 en TBG 12:208; van Voorneman TBG 11:438 en TBG 12:215; van Riedel TBG 12:217, 504, 539 en Notulen 2:154; van R. Moehamad Hoesin Notulen 1:289, 2:210, 231, 282.

127 Notulen 10:102, brief van Van der Tuuk, 20-6-1872. 
was, werd het voor de schooljeugd minder geschikt geacht. ${ }^{128}$ Daarmee kwam het genootschap direct terecht in het debat over de plaats van de islam in de Indonesische samenleving en de rol van zending en missie. Holle, die zich op verzoek van het gouvernement over Soendanese schoolboeken had gebogen, kwam over hetzelfde onderwerp in 1863 in conflict met de als theoloog opgeleide ambtenaar Koorders naar aanleiding van een boekje voor de Soendanese schooljeugd, dat vanuit een christelijk perpectief niet rechtzinnig was (Van den Berge 1998:122).

Het erelid Cohen Stuart deed in 1867 het voorstel om naast de Verhandelingen en het Tijdschrift nog met een aparte serie tekstuitgaven te beginnen onder de serietitel Werken, in navolging van het KITLV. De Verhandelingen zouden dan niet langer tekstedities bevatten, maar meer aan de uitkomst van wetenschappelijk onderzoek gewijd zijn. Cohen Stuart was onder meer op zijn voorstel gekomen doordat Klinkert had gewezen op de wenselijkheid van een aparte uitgave van de Sadjara Malajoe, terwijl Holle aanbeval om lontarhandschriften uit de Soenda-landen, die door Raden Saleh waren geschonken, uit te geven (Notulen 5:23-6).

Het bestuur besloot naar aanleiding van een nota van Cohen Stuart en boekhandelaar Lange om van dit plan vooralsnog af te zien. Men was bang dat de gouvernementssubsidie van $f 8.000$ per jaar niet zeker was en dus durfde het bestuur deze dure nieuwigheid niet aan (Notulen 5:26). Het lijkt er echter meer op dat het bestuur bang was zijn vingers te branden aan de Sadjara Malajoe. Holle vond in de gepubliceerde nota van Cohen Stuart aanleiding om op de inhoud van de Sadjara Malajoe in te gaan, die het ongewenste effect zou kunnen bewerken dat deze uitgave 'meer de herinnering aan de grootheid van het Maleische vorstenhuis, dan het bewustzijn, dat zij onder ons beter af zijn, bij de onder ons gezag staande Maleijers zal bevorderen' ${ }^{129}$ Holle verwees naar de kritiek van Klinkert op de schoolboekjes en bepleitte dat een midden zou worden gevonden tussen de belangen van de inhoud en die van de zuiverheid van de taal. Klinkert zelf, alsdus Holle, had boter op zijn hoofd als vertaler in het Maleis van enkele van die boekjes.

In de briefwisseling die volgde, steeds gericht tot het bestuur van het genootschap, komt Holle vooral als volksopvoeder en Cohen Stuart als cultuurrelativist naar voren. De paternalistische Holle gaf niet hoog op van de intellectuele capaciteiten van de inheemse, 'wiens politieke en godsdienstige horizont niet verder reikt dan zijn neus'. Voor hem waren de behoeften aan opvoedend materiaal, in de vorm van school- en leesboekjes, zo groot dat hij bereid was om desnoods de mindere kwaliteit van de gebruikte taal voor

128 TBG 8:288 vermeldt niet meer dan deze motivering. De notulen in ANRI KBG Dir 0223 (vergadering 16-9-1858) komen overeen met de gedrukte notulen.

129 Brief van Holle 29-6-1868, Notulen 7:Bijlage A, vergadering 5-1-1869, p. ii. 
lief te nemen. 'Wat baat het mij, of de drinkbeker van goud is, als hij vergift bevat? Dan drink ik liever water uit een behaarde klapperdop, al is dit niet kraakhelder!'130 Cohen Stuart erkende wel dat Holle niet rechtstreeks partij koos voor het 'brabbelmaleis' van sommige schoolboekjes, 'maar de geheele strekking van zijn vertoog brengt toch [...] eene mate van inschikkelijkheid op dit punt met zich, waarmede ik mij bezwaarlijk zou kunnen vereenigen'. ${ }^{131}$ De taalambtenaar Cohen Stuart ging vervolgens over tot commentaar op Klinkerts bespreking van de Maleise schoolboekjes, die Holle had aangezwengeld. Hij vond Klinkerts kritiek voor een deel gezocht, voor een deel ongegrond, vond dat de commentator het hier en daar rechtstreeks bij het verkeerde eind had, maar erkende dat er ook veel behartigenswaardigs in diens bespreking zat. Cohen Stuart nam liever afstand van het door het gouvernement geïnstigeerde systeem van prijsuitreiking aan wie ook maar enigszins geschikte schoolboekjes leverde, dan dat hij verder de discussie met Klinkert aanging. Hij kon trouwens niet nalaten en passant te vermelden dat hij voor geen van de besproken schoolboekjes als genootschaps- of gouvernementsbeoordelaar verantwoordelijk was. Hij vond dat het schrijven en vertalen van school- en leesboekjes voor het inheemse onderwijs alleen door moedertaalsprekers of door inschakeling van hen kon gebeuren en kon melden dat het vigerende systeem bij de overheid al in heroverweging was. ${ }^{132}$ Het onderwerp was in april 1868 zelfs al in de Tweede Kamer ter sprake geweest, toen de tot kamerlid gekozen Koorders, geen vriend van Holle, probeerde de begroting van het departement van koloniën te amenderen op het punt van het inheemse onderwijs in een poging om het bestaande systeem van schoolboekproductie met prijstoekenning de nek om te draaien (Van den Berge 1998:134-5). Overigens prees Cohen Stuart Holle zeer, omdat hij voor de Soendanese school- en leesboekjes wél inheemse schrijvers en vertalers had ingeschakeld.

Zo gematigd als Cohen Stuart zijn standpunt voor wat betreft de schoolboekjes naar voren bracht, zo radikaal wees hij het door Holle voorgestelde ingrijpen op het gebied van uitgaven voor het grote publiek af. Hij vond dat er geen sprake van censuur kon zijn, hoe goedbedoeld ook. Hij vond de door Holle genoemde voorbeelden, onder andere uit de Sadjara Malajoe, van hetzelfde kaliber als wat in de Nederlandse school- en volksliteratuur voorkwam. ${ }^{133}$ Hij vreesde dat bij het volgen van Holles adviezen alleen nog 'bloemlezingen of gezuiverde uitgaven' konden worden toegelaten en dat denkbeeld wees hij pertinent van de hand. Dit punt was natuurlijk voor het

Notulen 7:Bijlage A, vergadering 5-1-1869, p. ii.

Notulen 7:Bijlage B, brief van Cohen Stuart dd 7-7-1868, pp. vi-viii.

Notulen 7:Bijlage B, vergadering 5-1-1869, pp. viii-xi.

Notulen 7:Bijlage B bij de vergadering 5-1-1869, brief van Cohen Stuart, pp. iv-v. 
bestuur de reden geweest om de discussie tussen Holle en Cohen Stuart in de Notulen op te nemen. Tegelijk was het meegenomen dat Cohen Stuart Klinkert van repliek diende, waar het genootschap immers, als beoordelende instantie, in de zaak van de kwaliteit van de gepubliceerde schoolboekjes, niet vrij te pleiten was van medeverantwoordelijkheid. Ondertussen was het voorstel van de nieuwe serie uitgaven ('Werken') om financiële redenen in de ijskast gezet, wat het bestuur goed zal zijn uitgekomen, omdat ondertussen de discussie over de inhoud van de uit te geven werken kon uitrazen. In de bestuursvergaderingen kwam een en ander ongetwijfeld uitgebreider ter sprake dan de korte mededeling van het ter zake genomen besluit doet vermoeden. De omstandigheid dat het bestuur grotendeels uit ambtenaren van het gouvernement bestond en dat onderwerpen als onderwijs en volksopvoeding belangrijk waren, geeft aanleiding om dit te denken. Van der Chijs was er als inspecteur van het inheemse onderwijs het meest direct bij betrokken. Het feit dat het bestuur besloot de discussie Holle-Cohen Stuart te publiceren en er een honderdtal extra exemplaren als brochure van te drukken, geeft aan dat het onderwerp belangrijk genoeg was om breed te worden bediscussieerd. ${ }^{134}$ Een nadere brief van Holle over het onderwerp van 28 juni 1869 werd onderwerp van correspondentie tussen Van Limburg Brouwer en Holle om te kijken naar 'hetgeen uit deze bijdrage ter opname in het Tijdschrift kan worden genomen, met weglating van hetgeen tot verder geschrijf over het onderwerp zou kunnen aanleiding geven'. Voor het bestuur was de discussie gesloten. ${ }^{135}$ In andere media woekerde de discussie levendig voort (Van den Berge 1998:137-40).

De discussie tussen Holle en Cohen Stuart kan niet los gezien worden van de algemene gedachtenvorming die in de jaren 1860 gaande was over het inheemse onderwijs, over de taal die zou worden gebruikt in de inheemse scholen alsook over de manier waarop inheemse onderwijzers zouden worden opgeleid. In dat verband waren de school- en leesboekjes in de streektalen al vóór de kritiek van Klinkert en de bijval van Van der Tuuk aan de orde geweest. Niet toevallig waren het weer verzoeken van Holle, de altijd actieve ijveraar voor het Soendanees, die de discussie op gang hadden gebracht. Het ging om het voorstel om bestaande Maleise, Javaanse en Soendanese leerboekjes te laten vertalen in het Lampongs, Bataks en Makassaars en een tweede voorstel om een door Holle zelf vervaardigde lettertafel voor het Bataks te laten drukken ter verspreiding in de Bataklanden. Het gouvernement zag bezwaren en legde de zaak voor advies aan het genootschap voor, dat in een brief, opgesteld door Levyssohn Norman, aandrong op een 
grondige regeling van het inheemse onderwijs in de streektalen, op de opleiding van een 'keurbende' van Indonesiërs in Nederland, die dan later op de kweekscholen in de archipel zouden kunnen lesgeven en die veel beter dan de overwegend Nederlandse schoolboekenschrijvers in staat zou zijn tot het maken van geschikt lesmateriaal in de streektalen. Cohen Stuart wijdde aan de ontwerpbrief van Levyssohn Norman een aparte nota, waaruit bleek dat hij over zo'n opleiding van een keurbende in Nederland anders dacht. Hij stelde toen ook, naar aanleiding van het voorstel om schoolboekjes te vertalen in andere streektalen, het hele systeem van schoolboekproductie aan de orde, waarvan hij geen voorstander was. Het Bataviaasch Genootschap was aldus op een veel breder terrein gaan adviseren dan dat van de (studie van) de taal-, land- en volkenkunde in strikte zin. Het gaf adviezen waarop het gouvernement zijn onderwijsbeleid of beleidsveranderingen op dat terrein mede baseerde. ${ }^{136}$

\section{Verzamelingen: handschriften en inscripties}

Het laatste onderwerp dat tot de Indische taalkunde werd gerekend, vormde de collectie handschriften en inscripties, een belangrijke bron voor zowel historische als vergelijkende taalstudie, maar tevens voor de oudheidkunde en etnologie van belang. Het behoud en de uitbreiding van de collectie alsook de bestudering ervan voor de bovengenoemde vakken komen als onderwerpen in deze periode gedurig aan de orde. De collectie vormde een moeilijk tot een geheel te smeden verzameling, doordat de 'beschreven stenen' en de koperen platen met inscripties bij de beelden werden bewaard als onderdeel van de collectie oudheden, terwijl de handschriften op papier, palmblad en andere materialen bij de boeken in de bibliotheek waren opgeborgen. De handschriftenverzameling, inscripties in steen en koper nu even niet meegerekend, profiteerde in deze periode niet van grote aanwinsten, zoals dat in het verleden het geval was geweest. Was er in het begin van de jaren 1850 sprake van ongeveer 750 handschriften, grotendeels afkomstig uit de collectie van de sultan van Bantam en uit de Merbaboe-aanwinst, begin 1870 kwamen Cohen Start en Van der Chijs niet veel verder dan 780 stuks, waarvan 87 Javaanse, 53 Maleise, 130 Arabische en 508 op palmblad. ${ }^{137}$ Ter vergelijking: de Algemene Secretarie gaf in 1867 op dat zij beschikte over een verzameling

136 Notulen 4:32-50 voor de brief van Levyssohn Norman, en 51-80 voor Cohen Stuarts nota. Hieruit blijkt dat het systeem van prijstoekenning al eerder ter discussie stond. Zie ook Groeneboer 1993:193.

137 Verslag van de commissie Van der Chijs/Cohen Stuart in Notulen 8:15-8, vergadering 1-21870 . 
van 59 Maleise en Arabische handschriften, terwijl Klinkert vanuit Riouw opgaf over 81 Maleise handschriften te beschikken (Notulen 5:41-3, 4:191). De eerste gedrukte catalogus was die geweest van de Arabische handschriften door Friederich, in 1853 in de Verhandelingen verschenen. De tweede uitgave, weer van alleen de Arabische manuscripten, zou in 1873 door L.W.C van den Berg worden verzorgd (L.W.C. van den Berg 1873, 1877).

Friederich, de eerste conservator van de oosterse handschriften, vertrok in 1860 met verlof naar Europa. Hij werd pas in in maart 1864 opgevolgd door Cohen Stuart, vooral bekend met het Javaans door zijn jarenlange verblijf in Soerakarta. Naast Van der Chijs, die sinds januari 1861 bibliothecaris was, werd aan Cohen Stuart de zorg voor de collectie handschriften toevertrouwd. Toen hij zich in 1863, nog vóór hij formeel tot conservator werd aangesteld, over de handschriften boog, kwam hij maar tot vijftien (uitsluitend) Javaanse en 26 Arabisch-Javaanse en Maleis-Javaanse handschriften, een opgave die slechts een deel van de collectie omvatte. Als javanicus had hij voor deze manuscripten natuurlijk de meeste aandacht. Hij hield zich in eerste instantie niet bezig met de Maleise, Arabische, Balinese en andere handschriften. Hij boog zich wel over de koperen platen met Oud-Javaanse inscripties en ging onder meer ten rade bij Raden Pandji Soerja Widjaja, de Balinees Ida Ketoet Anom en Raden Pandji Koesoemo Adji Negoro, de patih van Tjiamis, voor ophelderingen, waar zijn kennis te kort schoot (Notulen 1:264-5 noten, 2:113). Het lithograferen of fotograferen van inscripties, in steen of koper, werd overwogen en door hem onderzocht, als een manier om wetenschappers in de gelegenheid te stellen nieuw gevonden inscripties te vergelijken met die in verzamelingen in Indië en Europa. ${ }^{138}$

Pas bij de algemene vergadering van 1864 viel er, mede dankzij de nieuw aangestelde conservator, iets substantieels te melden over de verzameling. In het jaarverslag had de verzameling nu een apart kopje gekregen, 'handschriften en inscriptiën', teken van de waardigheid van deze deelcollectie. Toen werden nieuwe aanwinsten gemeld, onder andere een handschrift van Pangeran Dipo Negoro, dat van het gouvernement ter vertaling was verkegen en waarop Cohen Stuart veel later nog zijn tanden zou stukbijten. ${ }^{139}$ Van de Merbaboe, dessa Bedakkan, kwam via de directeur van het museum, Levyssohn Norman, een verzameling lontarbladen binnen, terwijl andere schenkers (Sloet van de Beele, Pangeran Ario Soerjo Negoro, Holle, Teijsman, Diemont) een of enkele handschriften afstonden (Notulen 2:109-11). In 1865 en 1866 meldde het genootschap weinig aanwinsten. De oproep die het geplaatst had bij de leden en in de dagbladen, was nauwelijks beantwoord. Er was

138 Notulen 1:261, vergadering 12-9-1862; 2:112, algemene vergadering 30-4-1864.

139 Notulen 2:109, algemene vergadering 30-4-1864. Brief van Cohen Stuart aan Van der Tuuk, 19-11-1868 (Groeneboer 2002:185) over de vertaling van deze 'Babad Diponegoro'. 
vooral gevraagd naar historische babads, waarvan men aannam dat er daar veel van te verwerven waren. Wel was via Sloet van de Beele een Javaans manuscript met de Bedojo-zangen binnengekomen. In 1866 herhaalde het bestuur de oproep aan de leden, maar toen was er wat meer te melden. Er waren eenentwintig koperen platen bijgekomen, onder meer door een opgraving van vijftien platen bij Soerabaija en schenkingen van Pangeran Ngabehi en Raden Saleh. De collectie van voor-Mohammedaanse, koperen platen was door deze aanwinst opgelopen tot zevenendertig. Ook werd er toen gewerkt aan het afschrijven van een collectie Kawi-handschriften in Tjiboeroei, waarvan het bestaan door Holle was gesignaleerd. Toch vond het bestuur dat de pogingen om de verzameling uit te breiden in dat jaar 'vooralsnog niet die medewerking hadden ondervonden, waarop men gemeend had te mogen rekenen'. Vandaar dat de leden ('Mijne Heeren') nog eens van harte werden aangespoord (Notulen 3:59, 4:154-6).

Het had niet aan Raden Saleh gelegen dat het genootschap over het gebrek aan aanwinsten klaagde. De bekende schilder was met toestemming van het gouvernement in 1865 op een 'kunstreis' over Java vertrokken, waarbij hij verzocht had zich ook nuttig te mogen maken door oudheden en manuscripten te verzamelen die zich in het bezit van de inheemse bevolking bevonden. Cohen Stuart zag er veel in en toen de reis aan Raden Saleh werd toegestaan was het deze conservator die de reiziger instrueerde over de wensen van het genootschap. Raden Saleh werd tot lid van het genootschap benoemd. ${ }^{140} \mathrm{Hij}$ kwam onder meer terug met honderdvijftig oudheidkundige voorwerpen en achtendertig manuscripten op palmblad. De laatste werden op de algemene vergadering van 26 juni 1866 getoond aan de eenentwintig aanwezigen, onder wie Raden Saleh zelf. De schilder werd bij die gelegenheid tot erelid benoemd, nog geen jaar nadat hem het lidmaatschap was gegund. Waar hij mee terugkwam van zijn 'kunstreis' was voor de afdeling handschriften dan ook veruit de grootste aanwinst in vijf jaar tijd, al moesten sommige bamboehandschriften, nadat ze afgeschreven waren, weer naar de rechtmatige bezitters terug. Naast Raden Saleh waren vooral Holle en Sloet van de Beele voor de verzameling handschriften actief. De gulle schenkers waren inmiddels dus niet meer uitsluitend Europeanen. Het ontbreken echter van een gedrukte catalogus van de handschriften, alsook het uitblijven van een editie van de belangrijkste inscripties bevorderde het gebruik van de collectie niet, noch de kennis van wetenschappers in Europa en elders van wat de collectie te bieden had. 
Gebouwen: 'Een sieraad voor Nêerlandsch Indië's hoofdstad' (Uhlenbeck)

\section{Batavia}

In 1861 zag het er voor de toekomst van het genootschap somber uit. De regering bevestigde in september nog eens dat het niet zou betalen aan voorzieningen in de vorm van gebouwen voor de in Batavia gevestigde, belangrijkste organisaties, als ze niet tot een fusie zouden besluiten. Het bestuur nam er in de vergadering van 5 oktober nota van en besloot de commissie-Van der Chijs-Rochussen-Der Kinderen aan het werk te zetten om te zien of de al door het bestuur afgewezen fusie toch te realiseren zou zijn. ${ }^{141}$ Tijdens de algemene vergadering van 16 november werd in vogelvlucht (1853-1861) de sombere werkelijkheid door secretaris Der Kinderen nog eens aan de leden voorgehouden.

De nieuwe landvoogd, de in oktober 1861 aangetreden baron Sloet van de Beele, had het beschermheerschap van zijn voorganger Pahud overgenomen (Kern 1892). Sloet, die als een ijverig amateur-wetenschapper bekend stond, had nog voor het eind van het jaar met de aanbieding van de erefunctie ingestemd, 'niet slechts om eene gewoonte te volgen, maar uit warme belangstelling in alles wat wetenschap en kunsten betreft', aldus de nieuwe beschermheer in zijn acceptatiebrief. Hij was meteen het 'pakhuis' aan de Rijswijkstraat gaan bezoeken. ${ }^{142} \mathrm{Hij}$ was er door bibliothecaris Van der Chijs en secretaris, tevens conservator, Der Kinderen rondgeleid en had er ruim anderhalf uur de tijd voor genomen. Het was kennelijk geen erg formeel bezoek, want genootschapsvoorzitter Van Swieten en vice-voorzitter Wassink ontbraken. Dat door bibliothecaris en secretaris, de een bestuursambtenaar, de ander rechterlijk ambtenaar, bij hun hoogste baas de nood van het genootschap naar voren was gebracht, lijkt vanzelfsprekend. ${ }^{143}$ Zowel de slechte staat van de gebouwen als de door de regering in de Den Haag en door het gouvernement in Batavia beoogde samensmelting van de drie belangrijkste gesubsidieerde, particuliere organisaties zullen zijn besproken, al zeggen de notulen daar niets over. Rapporteerde de commissie-Van der Chijs in januari 1862 nog over de mogelijke uitweg uit de impasse tussen genootschap en overheid met betrekking tot de fusie in een rapport dat in het bestuur werd

\footnotetext{
141 TBG 12:144-5, vergadering 5-10-1861.

142 TBG 12:168. De term 'pakhuis' werd gebruikt door secretaris Der Kinderen in zijn 'Overzigt over de jaren 1853-1861', grotendeels door Netscher opgesteld en voorgelezen tijdens de algemene vergadering 16-11-1861. De acceptatiebrief van Sloet werd vermeld in TBG 12:222, vergadering 4-1-1862, maar niet in de notulen opgenomen. De door Sloet eigenhandig geschreven brief, waaruit het citaat, in ANRI KBG Dir 0260, vergadering 4-1-1862.

143 TBG 12:153-4, vergadering 16-11-1861, en 222-3, vergadering 4-1-1862.
} 
rondgelezen, in de eropvolgende maanden meldden de notulen niets meer over het commissievoorstel. ${ }^{144}$

Het rapport bestond uit een negentiental 'Concept-voorwaarden van vereeniging der drie te Batavia gevestigde wetenschappelijke ligchamen' en werd op 15 april 1862 door Der Kinderen aan de Natuurkundige Vereeniging en de Maatschppij van Nijverheid gestuurd. Wat de commissie voorstelde was eerder een federatie van drie organisaties, dan een echte fusie. De drie zouden zich verenigen tot één, maar wel blijven bestaan uit drie onderscheiden afdelingen. De afdelingen zouden ieder beurtelings de voorzitter leveren en ieder een eigen bestuur, eigen wetten en eigen geldmiddelen houden. Dat alles zou onder één hoofdbestuur moeten functioneren, dat gevormd zou worden uit de drie voorzitters, secretarissen en penningmeesters. In het voorstel was zoveel mogelijk geprobeerd het eigen karakter van de bestaande organisaties te handhaven. Heikele kwesties, zoals een nieuwe naam en de hoogte van de contributie waren nog niet opgelost. Al met al maakt het voorstel een nogal zwakke indruk. ${ }^{145}$ Namens de Natuurkundige Vereeniging antwoordde secretaris Versteeg in mei 1862 dat zijn bestuur zich van advies zou onthouden. Pas als de voorwaarden door het genootschap zelf zouden zijn aangenomen, aangeboden aan de regering en dan weer door de regering aan de vereniging gestuurd, zou zijn vereniging een mening willen geven. Namens de Maatschappij van Nijverheid hadden voorzitter $H$. de Bruijn en bestuurslid Netscher laten weten dat de voorwaarden door de algemene vergadering van de maatschappij op 17 april 1862 waren aangenomen. ${ }^{146}$ Met deze brieven werd, afgaande op de gedrukte notulen, niets gedaan. Ze kwamen zelfs niet ter sprake. Het heeft er alle schijn van dat informeel bekend was dat een uitweg uit de ontstane impasse in de maak was.

\section{Den Hagg}

Die uitweg werd niet in Batavia, maar in Den Haag gevonden en wel door de nieuwe minister van koloniën, de nog maar net in patria teruggekeerde Gerard Hendrik Uhlenbeck (1815-1888). Uhlenbeck was in Colombo geboren, had in Nederland een technische opleiding gevolgd, om in 1837 als tweede luitenant van de genie naar Indië te vertrekken. Als adjudant van de directeur van de genie in Batavia begon hij zijn carrière. Hij was één van de

\footnotetext{
144 TBG 12:227, vergadering 4-1-1862.

145 Concept-voorwaarden met de aanbiedingsbrief van Der Kinderen aan de Natuurkundige Vereeniging en de Maatschappij van Nijverheid, 15-4-1862, in ANRI KBG Dir 1517, omslag 40 (1862).

146 Brief van Versteeg van mei 1862 (geen datum) en brief van De Bruijn en Netscher, 26-5-1862 in ANRI KBG Dir 1517, omslag 40 (1862).
} 
ondertekenaars van het rekest aan de koning van 25 mei 1848, waarin om de afschaffing van het radikaal werd gevraagd. Beroepsmatig was hij betrokken bij de voorbereidingen voor de spoorwegaanleg in de Vorstenlanden in de jaren veertig. In 1853 werd hij benoemd tot chef van de Waterstaat en 's Lands Civiele Werken. Die dienst werd in 1855 omgevormd tot Departement van Burgerlijke Openbare Werken (BOW), waarvan Uhlenbeck de eerste directeur werd (Ravesteijn en Kops 2004). Hij nam toen ontslag uit militaire dienst. Onder zijn toezicht was in 1858 door ingenieur P.J.G. Beijerinck een ontwerp gemaakt voor een nieuw gebouw op het Harmoniecomplex ten behoeve van het genoootschap. Dat plan werd niet verwezenlijkt, omdat het te duur was en omdat de overheid eerst de al besproken fusie gerealiseerd wilde zien. Uhlenbeck werd betrekkelijk laat lid van het genootschap, namelijk op 4 juni 1859, in dezelfde vergadering als H.D. Levyssohn Norman. ${ }^{147}$ Toen Uhlenbeck in april 1861 met verlof naar Nederland vertrok, was hij goed op de hoogte van de bouwvalligheid van het bestaande genootschapshuis. Hij wist dat het museum, de voormalige kolfbaan, was ontruimd en dat de toestand van het gebouw in de Rijswijkstraat nijpend was. Uhlenbeck was voorzitter geweest van de Maatschappij van Nijverheid en uit dien hoofde was hij goed bekend met de problematiek van de 'fusie der maatschappijen'. Op 1 februari 1862 trad hij in het nieuwe, door Thorbecke geleide kabinet aan als minister van koloniën.

Als gouverneur-generaal trof hij een andere spoorwegman aan: Sloet van de Beele, voormalig voorzitter van de raad van toezicht op de spoorwegdiensten in Nederland. Sloet was eind augustus 1861 naar Indië vertrokken en mogelijk had hij Uhlenbeck in zijn periode van voorbereidingen op het vertrek ontmoet. Sloets bezoek aan het pakhuis in de Rijswijkstraat is veelbetekenend geweest voor de toekomst van het genootschap. Daardoor kende hij de situatie net zo goed als Uhlenbeck. Vermoedelijk stond Sloet van het begin af aan niet achter het idee van de door Pahud voorgestane fusie.

Precies een maand na zijn aantreden als minister nam Uhlenbeck het initiatief. Het genootschap had in hem geen beter vriend en pleitbezorger kunnen wensen. Op 1 maart 1862 schreef hij een notitie, waarin hij zonder omwegen voorop stelde:

Ik wensch dat de daarstelling van een nieuw gebouw voor museum etc., en de bijeenkomsten van het Bataviaasch genootschap van kunsten en wetenschappen tot een onderwerp van voordragt aan den Koning worde gemaakt; en naar aanleiding van de hier berustende stukken [...] worde voorgesteld: op het tegenwoordige emplacement een nieuw, doelmatig en om aan de

147 TBG 9:238, vergadering 4-6-1859. Tijdens dezelfde vergadering werd A. Prins tot bestuurslid en generaal Van Swieten tot voorzitter gekozen, terwijl hijzelf afwezig was. 


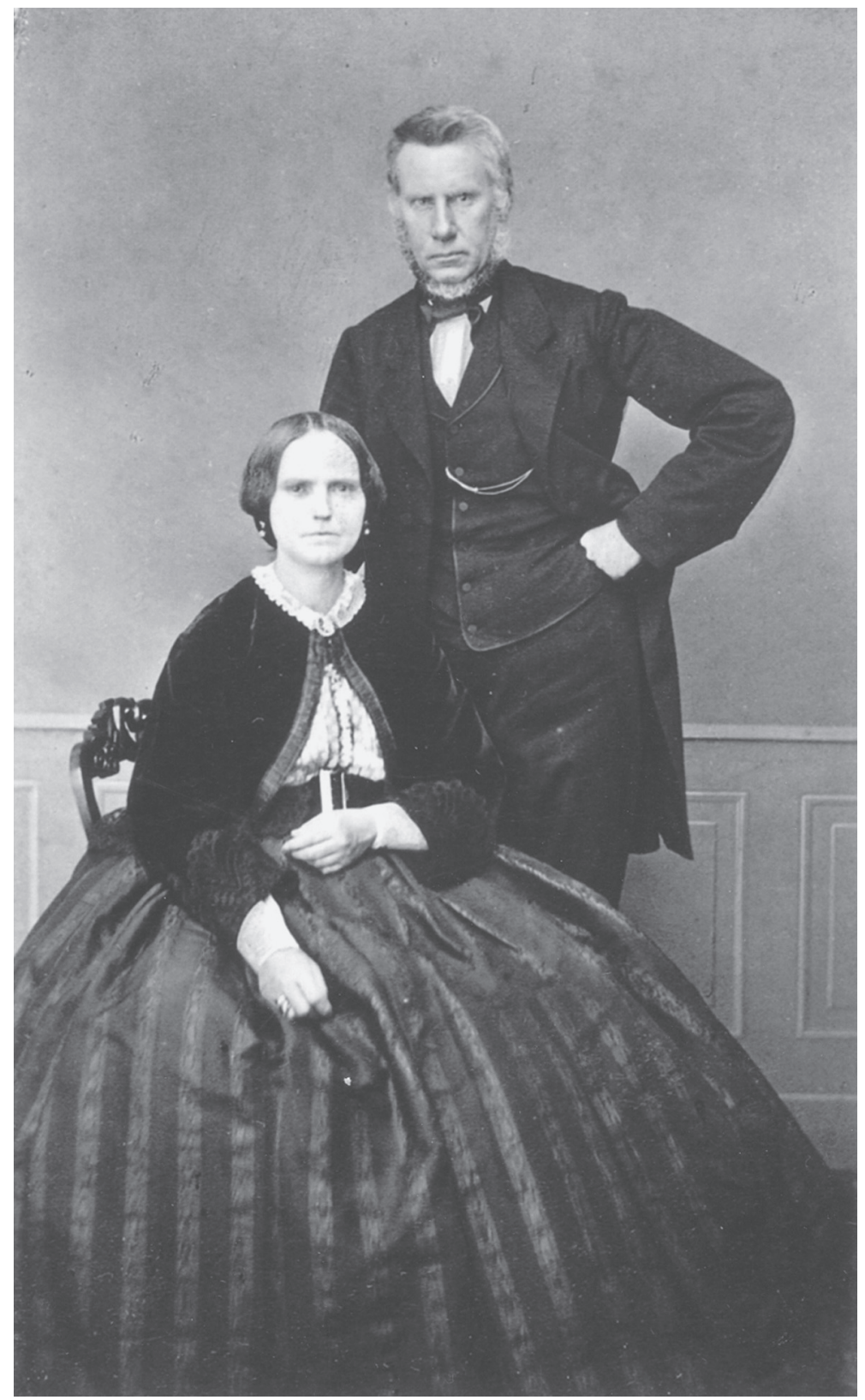

Dubbelportret van Gerhard Hendrik Uhlenbeck, directeur van BOW en later minister van koloniën, en zijn echtgenote, Maria Catharina Godin (carte de visite, collectie RKD/Iconografisch Bureau Den Haag D 3447) 
behoeften gedurende plusminus een kwart eeuw te bevredigen gebouw; om te strekken tot museum en bewaarplaats van gouvernements geschenken, zoomede boekerij, behoorende aan en staande onder toezigt van het Bat.gen.

Uhlenbeck gaf direct enkele randvoorwaarden aan: het gebouw moest in 1863-1864 gerealiseerd worden en mocht $f 175.000$ gaan kosten. Het genootschap zou het onbezwaard vruchtgebruik krijgen en bovendien in 1863-1864 $f 2.400$ extra subsidie ontvangen om tijdelijke huisvesting te huren. ${ }^{148}$ De ambtenaren van het ministerie kwamen direct in actie en leverden de minister in de maand april drie nota's: A. over de wenselijkheid van de samensmelting van wetenschappelijke lichamen in Nederlands-Indië, B. over de bouw van een museum voor het genootschap, en C. over 's Lands Plantentuin in Buitenzorg. Uhlenbeck wees op 18 april 1862 resoluut de eerste rapporteur terecht: 'De ondergetekende wenscht van landswege slechts één gebouw te doen daarstellen voor het oudste der in Indië gevestigde wetenschappelijke genootschappen.' Hij wilde niet meer met de gouverneur-generaal over de samensmelting van de drie organisaties in briefwisseling treden. Voor een alternatief, de oprichting van een geheel nieuwe door het rijk aangestuurde Indische academie van wetenschappen, achtte hij de tijd nog lang niet rijp. ${ }^{149}$ De schrijver van nota B kreeg op dezelfde dag van zijn minister een soortgelijke afwijzing te lezen.

Schrijver dezer nota zal ontwaren uit de in het rapport aan de Koning gemaakte veranderingen [...] dat ik niet beoog eene ineensmelting der drie vereenigingen en beschouwe dat zij zeer gevoegelijk en met meer vrucht naast elkander kunnen bestaan en bloeijen.

Op nota $C$ had Uhlenbeck al een paar dagen eerder geschreven dat hij de zaak van de Buitenzorgse plantentuin helemaal buiten deze kwestie wilde laten en die aan de Indische regering wilde overlaten. ${ }^{150}$

Op 19 april 1862 legde Uhlenbeck de zaak aan Koning Willem III voor. In de brief verwees hij naar eerdere beschikkingen van de koning inzake subsidieverlening aan de wetenschappelijke organisaties in Batavia. Hij legde uit dat het genootschap in een bouwvallige ruimte gehuisvest was en onvoldoende plaats had voor 'de niet onbelangrijke bibliotheek, de niet onaanzienlijke verzameling van het genootschap van voorwerpen, voornamelijk op de land- en volkenkunde van Nederlandsch Indië betrekking hebbende'. Verder suggereerde hij dat vreemde bezoekers een 'treurig denkbeeld' kon-

A.
NA Koloniën verbaal 19-4-1862 nr 35 bevat deze notitie van 1-3-1862.

NA Koloniën verbaal 19-4-1862 nr 35, notitie van Uhlenbeck, 18-4-1862 op p. 36 van rapport

Nota's B en C met Uhlenbecks commentaar in NA Koloiën verbaal 19-4-1862 nr 35. 
den krijgen van de belangstelling in Indië voor zulke zaken, een argument dat Uhlenbeck in 1859 al naar voren had gebracht om toenmalige plannen voor nieuwbouw kracht bij te zetten. Vervolgens wees hij het idee van de samensmelting af met als argument onder meer dat hij persoonlijk goed op de hoogte was met de stand van zaken in Batavia. Tenslotte stelde hij vast dat er geen gouvernementsmuseum was en dat de Indische regering voorwerpen van belang steeds ter bewaring aan het genootschap gaf. Daarna kwam zijn voorstel om te besluiten tot het oprichten van het gebouw

om te strekken tot museum en bewaarplaats van gouvernementsgeschenken en voor de boekerij, behoorende aan en staande onder toezigt van het Genootschap, zoomede voor zijne openbare en bijzondere bijeenkomsten en vergaderingen. ${ }^{151}$

De financiële kaders waren zoals hierboven door Uhlenbeck al op 1 maart 1862 vastgesteld.

De koning reageerde op 22 april 1862 instemmend, zodat Uhlenbeck op 24 april (de 84e verjaardag van het genootschap) aan Sloet van de Beele het goede nieuws kon berichten. Hij voegde er nog persoonlijk aan toe:

Het is mij zeer aangenaam Uwer Exc. deze mededeeling te mogen doen, en op deze wijze te hebben mogen medewerken tot de vervulling eener behoefte, welke in Indië sedert jaren was gevoeld. [...] terwijl ik ook de wensch uitdruk, dat er naar zal worden gestreefd om het nieuw opterigten gebouw, met vermijding van alle onnodige weelde, toch een sieraad voor Nêerlandsch Indië's hoofdstad te doen zijn. ${ }^{152}$

Met het vorstelijke besluit waren eerdere plannen, zoals het nog door Uhlenbeck in 1859 gedane voorstel om op het kolfbaanemplacement te beginnen met de stichting van een nieuw gebouw voor $f 25.500$ als tijdelijke huisvesting voor het genootschap, van de baan. Eerst zou nu het gebouw in de Rijswijkstraat worden afgebroken en daar zou dan in twee jaar tijd de nieuwbouw verrijzen.

\section{Batavia}

Het gouvernementsbesluit van 22 juni 1862, dat op de beslissing uit Den Haag was gebaseerd, gaf in Batavia bekendheid aan de verrassende ontwikkeling. Genootschapsbestuur en gouvernement konden nu aan de slag. Het bestuur belegde een vergadering met Uhlenbecks opvolger als directeur BOW, $\mathrm{H}$. de Bruijn, en schreef een brief aan Sloet van de Beele met verzoek om door

152 NA Koloniën verbaal 24-4-1862 nr 41, waarbij ook het Koninklijk Kabinetsrescript van 22-41862 no 44.1. 
tussenkomst van de minister van koloniën de dank van genootschap aan de koning over te brengen. ${ }^{153}$ Op 8 augustus 1862 vond een eerste vergadering plaats met de directeur BOW. Daarbij werd een pakket van eisen opgesteld, waaruit men zich een beeld kan vormen van het gewicht dat aan de verschillende afdelingen werd gehecht. De volgende ruimtes zouden het nieuwe gebouw vullen (de afmetingen zijn in vierkante meters).

Beoogde indeling van het nieuwe museum (situatie 1862) ${ }^{154}$

\author{
hoofdgebouw \\ bibliotheekzaal \\ leeszaal \\ kamer bibliothecaris \\ archeologische zaal \\ kamer munten/penningen \\ kamer voor kostbaarheden \\ 2 open loodsen (grote voorwerpen) \\ vergaderzaal \\ kamer voor archief/secretaris \\ kamer voor de concierge \\ bijgebouwen \\ woonruimte concierge \\ magazijn \\ 6 bediendenwoningen met keuken \\ 2 latrines ('inodores') \\ 1 wagenloods voor 24 wagens
}

Voor zover er indicaties voor de afmetingen waren vastgesteld, gingen de wensen van het bestuur uit naar een gebouwencomplex met een vloeroppervlak van circa 2.400 vierkante meter (bijgebouwen meegerekend), waarvan de 'zalen' ongeveer 65\% in beslag zouden nemen, de bibliotheek niet meegerekend. De genootschapsnotulen zeggen niet veel over de overige behoeften

153 Brief aan directeur BOW, 14-7-1862 en brief aan de gouverneur-generaal, 15-7-1862 in ANRI KBG Dir 0996, uitgaande correspondentie, nr 179 en 190.

154 TBG 12:589-90, vergadering 8-8-1862. De afmetingen zijn in vierkante ellen opgegeven, hier omgerekend naar vierkante meters. 
voor het gebouw. Er werd aandacht gevraagd voor licht en lucht in de zalen, voor een goede verhouding tussen hoogte en vloeroppervlak en voor de mogelijkheid om de archeologische voorwerpen amfitheatergewijs te kunnen opstellen. Er werd wel aan werkruimte voor de bibliothecaris, secretaris en de concierge gedacht, een werkruimte voor de directeur van het museum werd niet in het programma opgenomen.

In oktober bleek de directeur van BOW problemen te hebben om het program van eisen uit te voeren op het terrein aan de Rijswijkstraat. Daarnaast leek hij ook met het geld niet uit te komen. Hij suggereerde het genootschap de eisen te matigen, minder gericht op de toekomst, meer conform de bestaande situatie. Het genootschap moest zich, met andere woorden, met een kleiner gebouw tevreden stellen. De Bruijn stelde voor om een alternatieve locatie te zoeken aan een van de kanten van het Koningsplein. Tevens stelde hij voor om aan het project een prijsvraag te verbinden. Het bestuur nam de suggestie van het Koningsplein direct over en vroeg de gouverneur-generaal op 15 oktober 1862 op de voorwaarde van de locatie, die van het oude gebouw, zoals dat in het koninklijk besluit was vastgelegd, terug te komen. De zuidzijde van het Koningsplein leek de ideale plek te zijn. Verder hoopte het te kunnen gebruik maken van de opbrengst van een openbare verkoping van het gebouw aan de Rijswijkstraat, waardoor de beschikbare bouwsom groter zou uitvallen. Tenslotte ging het met het prijsvraagidee akkoord. ${ }^{155}$ Een paar dagen later nam De Bruijn in een brief aan de gouverneur-generaal de voorstellen van het bestuur over. Overigens week hij daarmee af van de ideeën die zijn ondergeschikte, hoofdingenieur Beijerinck, had geventileerd. Die was namelijk op 22 september uitgekomen op een plek aan de westzijde van het Koningsplein.

Gouverneur-generaal Sloet van de Beele moest nu met minister Uhlenbeck overleggen over de bouwlocatie. In een brief van 11 november $1862 \mathrm{kwam}$ hij met een sluwe vondst voor de dag. Hij confronteerde zijn minister met een brief van de directeur BOW van 2 april 1858 (toen: Uhlenbeck) waarin over het emplacement in de Rijswijkstraat gesteld werd: 'Dan rijst de vraag of aan de bouw van nieuwe, beter ingerigte en dus ook meer aan de tegenwoordige behoefte geëvenredigde lokalen op een ander, ruimer terrein niet verreweg de voorkeur moet worden gegeven'. Sloet was het helemaal met het genootschap en met Uhlenbecks ideeën uit 1858 eens dat tot een andere locatie moest worden besloten. Het bestaande gebouw verkopen en de opbrengst aan de beschikbare bouwsom toevoegen, ging hem echter te ver. Interessant zijn de stedebouwkundige ideeën die Sloet onder Uhlenbecks aandacht bracht. In de

155 Notulen 1:35-6, vergadering 11-10-1862. De brief aan de gouverneur-generaal, 15-10-1862 nr 256 in ANRI KBG Dir 0996, correspondentie 1861-1864. Afschrift in NA Koloniën verbaal 3-1$1863 \mathrm{nr} 45 / 10 \mathrm{~b}$. 
brief schetst hij een herinrichting van het Koningsplein met midden op het plein een nieuw 'hotel' voor de gouverneur-generaal, aan de noordkant een nieuw gebouw voor de algemene secretarie en aan de zuidzijde het nieuwe gebouw voor het genootschap. Daarmee zou een fraaie indeling van het plein ontstaan met monumentale gebouwen. Sloet sloot af met het voorstel om in ieder geval de beperking tot de locatie in de Rijswijkstraat direct in te trekken. ${ }^{156}$

\section{Den Haag}

Uhlenbecks dagen als minister waren inmiddels geteld. Zijn liberale ideeën en zijn ministeriële onervarenheid ondervonden tegenstand in het parlement. Zijn voorstel voor een nieuwe regeling voor de cultuurondernemingen werd veel te radicaal gevonden. De Eerste Kamer keurde de begroting van koloniën af en Uhlenbeck diende zijn ontslag in. Op 3 januari 1863 werd hem dat verleend. Daags tevoren had hij de koning voorgesteld om conform de voorstellen van Sloet van de Beele de voorwaarde 'ter plaatse van het tegenwoordige gebouw' in te trekken. Op 3 januari had de koning ingestemd en nog vóór Uhlenbeck het ministerie voorgoed verliet, had hij Sloet geschreven dat het genootschap niet meer gebonden was aan de oude locatie in de Rijswijkstraat. ${ }^{157}$ Uhlenbeck wilde met deze stap kennelijk voorkomen dat de bouw van het nieuwe museum vertraging zou oplopen doordat zijn opvolger misschien anders over de zaak zou denken. Het genootschap was Uhlenbeck veel dank verschuldigd voor deze tijdige beslissing. Het benoemde de oud-minister tot erelid en stuurde hem daarvan in een dankbrief bericht. Uhlenbeck reageerde vanuit Den Haag opgetogen op zijn erelidmaatschap:

Een heugelijke dag zal het voorzeker zijn, wanneer de eerste steen van het gebouw voor het genootschap bestemd wordt gelegd; maar nog verblijdender zal het zijn, wanneer het voltooid tot Sieraad strekt van Java's hoofdstad, en feestelijk kan worden ingewijd. ${ }^{158}$

156 NA Koloniën verbaal 3-1-1863 no 45/10b, waarin de brief van de gouverneur-generaal aan de minister van koloniën, 11-11-1862 no 898/12.

157 NA Koloniën verbaal 2-1-1863 nr 7 en verbaal 3-1-1863 nr 45/10b waarin ook het koninklijk kabinetsrescript van 3-1-1863 nr 80.

158 ANRI KBG 0996, 5-3-1863 nr 346. Zie ook Notulen 1:77-8, vergadering 24-2-1863. De dankbrief van Uhlenbeck van 13-5-1863 bevindt zich in de bundel correspondentie over 1863, ANRI KBG Dir 0281. 


\section{Batavia}

In afwachting van de beslissing uit Den Haag over de locatie werden het conceptprogramma en de prijsvraag uitgewerkt, uitgaande van de gedachte dat het wel goed zou komen. In januari 1863 werden deze in de krant gepubliceerd (Javasche Courant 24, 28 en 31-1-1863). De formulering van de prijsvraag, waarvoor de inzendingen op 1 juni 1863 binnen moesten zijn, geeft interessante aanwijzingen voor de veranderingen die ten aanzien van het pakket van eisen van augustus 1862 waren aangebracht. De bouwsom van $f 175.000$ en een langwerpig vierkant of rechthoekige vorm werden als beperkingen aangegeven, maar het aantal idealiter te realiseren vierkante meters werd niet genoemd. Daarin waren de inzenders kennelijk vrij. Wel werd gevraagd om een gebouw dat van alle kanten 'een schoon bouwkundig karakter zou bezitten', waaruit af te lezen valt dat de locatie op Koningsplein-Zuid nog steeds favoriet was. Daar kon een vrijstaand gebouw verrijzen waarop de toeschouwer van vier zijden zicht had. In de bibliotheek moesten 8.000 banden geplaatst kunnen worden in de boekenkasten die het genootschap uit de Rijswijkstraat zou meenemen. Een uitbreiding tot 20.000 banden moest mogelijk zijn. Verder moest de etnologische verzameling drie maal zoveel ruimte krijgen als de archeologische. De vergaderzaal zou iets kleiner mogen zijn dan het archeologische kabinet. Het mineralogisch kabinet en de leeszaal mochten iets kleiner zijn dan de vergaderzaal, en de kamers voor de munten en penningen en voor de kostbaarheden op hun beurt weer iets kleiner. De bibliothecaris en de secretaris zouden nog weer kleiner gehuisvest worden. Voor grote voorwerpen zouden op het terrein nog een of twee open, maar wel overdekte gebouwen nodig zijn, ter grote van de ruimte voor het archeologisch kabinet. Meest opvallend is wel dat de oppervlakte van het hoofdgebouw - in augustus 1862 nog begroot op 2.400 vierkante meter - niet in de prijsvraagopgave was opgenomen.

In maart werd de zevenkoppige commissie ter beoordeling van de te verwachten inzendingen geformeerd. Ze bestond uit genootschapsvoorzitter Wassink en -secretaris Der Kinderen, die van hun kant ook de directeur van BOW, De Bruijn, voorstelden als lid. Deze droeg zijn ondergeschikten, de ingenieurs P.J.G. Beijerinck, jhr. W.F.H.F. de Raders en C.F. Deeleman, naast de genie-kapitein Versteeg (erelid van het genootschap) voor. ${ }^{159}$ Tijdens de algemene vergadering van het genootschap van 27 maart 1863 werd de optimistische verwachting uitgesproken dat binnen twee jaar het nieuwe gebouw kon worden betrokken. ${ }^{160}$ Het zouden er ruim vier worden.

160 Notulen 1:165-9, algemene vergadering 27-3-1863. 
De rest van 1863 ging heen met het wachten op en met het beoordelen van prijsvraaginzendingen. In februari 1864 stelde de Raad van Indië vast dat het jaar 1863 was verlopen zonder dat een voorstel was goedgekeurd. ${ }^{161}$ Hoe de wel ingediende voorstellen er dan uit zagen, komen we nergens aan de weet. Ruim anderhalf jaar na het vorstelijk gebaar bleken er eerst allerlei problemen uit de weg te moeten worden geruimd. Het hoofdprobleem was gelegen in het beoogde terrein op de zuidkant van het Koningsplein, een ruim en van vier kanten zichtbaar perceel waarop een gebouw zou moeten komen dat aan vier zijden de uitstraling van een sieraad had. Dat zou het te duur maken. Het gouvernement had een alternatief bedacht: een terrein aan de westkant van het plein, maar niet op het centrale plein zelf, maar aan de andere kant van de weg die het plein omsloot, op de plek waar vroeger de stallen van de Bataviasche Race-club hadden gestaan. ${ }^{162}$ Door een van de ingenieurs van het departement van De Bruijn was een alternatief plan uitgewerkt voor het bedoelde perceel, waarvan het genootschap inzage kreeg. Het genootschapsbestuur bedacht allerlei bezwaren en uitwegen. Het vond het perceel op de zuidkant van het plein veel geschikter. Een gebouw met één front was minder een 'sieraad' dan een gebouw met vier fronten. Het perceel aan de westkant zou te klein zijn en bovendien grensde het aan een stinkende sloot, 'het wel niet steeds welriekend spruitje Menteng'. Het bestuur zou, als het zelf kon beschikken over de $f 175.000$, het hele project wel onder zijn hoede nemen, zoals Holle ook de kweekschool voor inheemse onderwijzers te Bandoeng had mogen bouwen. ${ }^{163}$ De gouverneur-generaal nam nu snel een besluit. Op 23 februari koos hij tegen de zin van het genootschap voor het perceel aan de westzijde van het plein, waar het gebouw, nu het Nationaal Museum van Indonesië, nog steeds staat. Hij gaf het genootschap het project niet in handen, het zou een BOW-project blijven, en hij vroeg het bestuur vóór 15 april 1864 bezwaren tegen de klaarliggende plannen in te dienen. ${ }^{164}$ Het was bijna twee jaar na de beslissing in Den Haag en er was nog geen spade in de grond gezet.

Zoals in 1858 een project was gepresenteerd, dat door ingenieur Beijerinck was ontworpen, zo bleek nu de eerste ingenieur bij hetzelfde departement, De Raders, zelf lid van de prijsvraagcommissie, de ontwerper te zijn van een gebouw dat op Koningsplein-West zou verrijzen. ${ }^{165}$ De prijsvraag was helemaal van de baan. Het bestuur maakte haast met het doen van voorstellen voor veranderingen in De Raders' project: liever één grote zaal voor de

165 Notulen 2:56, vergadering 12-3-1864.

Notulen 2:1-2, vergadering 9-1-1864.

Notulen 2:4-5, vergadering 9-1-1864.
ANRI Algemene Secretarie besluit 23-2-1864; Advies Raad van Indië, 12-2-1864.

ANRI Algemene Secretarie besluit 23-1-1864 nr 1. Zie ook Notulen 2:52-3, vergadering 12-3- 
etnologische afdeling dan verschillende kleinere; liever geen binnengangen, maar open galerijen en een vestibule met een marmeren vloer en met bovenlicht; liever een andere verdeling van de ruimtes over het gebouw, een andere aansluiting van de vestibule op de binnengalerijen en nog enkele, kleinere punten. De Raders kreeg deze suggesties toegestuurd, vergezeld van tekeningen van de bestuursleden Levyssohn Norman en P. van Swieten, directeur van het Gymnasium Koning Willem III en pas sinds 1863 lid van het bestuur, en een samenvattende nota van Versteeg. ${ }^{166}$ Op basis van de tekening van Van Swieten werd op 22 maart 1864 een discussie met architect De Raders gevoerd. ${ }^{167}$ Die stuurde nog in april het definitieve project aan het bestuur, ${ }^{168}$ waarna nog enig overleg volgde en de gouverneur-generaal op 30 juli 1864 het project definitief goedkeurde. ${ }^{169}$ Eindelijk kon de bouw beginnen.

Bij gebrek aan een uitgebreide beschrijving met tekeningen van de architect moeten we ons een voorstelling maken van het gebouw aan de hand van plattegronden (1877), van de eerste foto's en van beschrijvingen. Heel beeldend gaf secretaris Levyssohn Norman, tevens directeur van het museum, tijdens de algemene vergadering van 30 april 1865 een beschrijving van een virtuele wandeling door het nieuwe gebouw, waarvan de echte bezichtiging nog tot 1867 moest wachten (Notulen 3:76-8). Hij kon melden dat de vloeren er lagen, dat het in 1865 onder dak zou komen en eind 1866 gereed zou zijn.

Het gebouw zou het aanzien krijgen van een Griekse tempel met Dorische zuilen. Men zou tussen de zuilen door een paar treden oplopen om in de met marmer beklede vestibule aan te landen, het gevoel hebbend dat men in een tempel binnentrad, van waaruit men door een colonnade zou treden in de archeologische afdeling, recht achter de ingang. Daar zou men de hindoe-tijd binnenstappen. Daarom was achter de vestibule voor een Indische bouworde gekozen, in afwijking van de Grieks-Dorische van het geheel. In de archeologische afdeling kwamen dan op naar de muren toe oplopende trappen - amfitheatergewijs - de voorwerpen te staan. Aan de voorzijde van het gebouw zouden aan weerskanten van de vestibule telkens twee ruimtes zijn: links een grote vergaderzaal en een kleinere voor de munten en penningen, rechts een grote zaal voor de etnologische afdeling en een kleinere voor de kostbaarheden van het genootschap. De rest van de linkervleugel werd bijna helemaal in beslag genomen door de bibliotheek, de leeszaal en de werkruimte van de bibliothecaris over drie verschillende ruimtes verdeeld. De rechtervleugel zou worden gedomineerd door een tweede grote etnologische

\footnotetext{
166 Notulen 2:54-5, vergadering 12-3-1864.

167 Notulen 2:74-5, vergadering 22-3-1864.

168 Notulen 2:156, vergadering 7-5-1864.

169 ANRI Algemene Secretarie besluit 30-7-1864 nr 13 bevat wel de tekst van het besluit, maar geen tekeningen. Zie ook Notulen 2:200-2, vergadering 6-8-1864.
} 
zaal die tot de achterzijde van het gebouw zou doorlopen.

Men moest zich het museum dus voorstellen als een centraal, tempelachtig gedeelte, waarachter de oudheden een plaats zouden vinden voorzien van twee gelijke vleugels, waarvan de ene zou worden gebruikt voor vergaderen, boekenopslag, lezen en voor het munten- en penningenkabinet, terwijl de rechtervleugel geheel als tentoonstellingsruimte gebruikt zou worden. De vleugels zouden zowel aan de binnenzijde als aan de buitenkant van het gebouw worden gesierd met dezelfde Dorische zuilen, die ook de voorkant kenmerken, waardoor het idee van een Griekse tempel versterkt werd. De zes zuilen van het voorportaal en de vijftien van de zijkanten gaven het geheel een statig, plechtig uiterlijk, met reminiscenties aan de Griekse tempels op Sicilië. De zuilen kwamen zowel in de vestibule als in de galerijen aan de binnentuin terug. Met recht een tempel voor de muzen.

Men verwondere zich er niet over dat Levyssohn Norman tijdens zijn wandeling het mineralogische kabinet oversloeg: dat was begin 1865 overgedragen aan de Koninklijke Natuurkundige Vereeniging, waardoor er extra ruimte beschikbaar kwam voor de andere delen van de verzamelingen.

Achter de vleugels was nog terrein beschikbaar voor een tuin, onder meer voor de grote en zware voorwerpen, terwijl achter op het perceel, niet ver van het spruitje Menteng, het magazijn, de wagenloods, de conciergewoning en de bediendenvertrekken kwamen. Het gebouw zou aan de voorzijde 56 meter breed zijn, de vleugels zouden 32 meter diep en 16 meter breed worden. Van de in eerste instantie gevraagde 2.400 vierkante meter waren er in het hoofdgebouw circa 1.800 gerealiseerd. Op een foto uit circa 1868, waarschijnlijk genomen nog voor de ingebruikneming, ziet men het gebouw haast zonder beplanting en kan men zich dus goed voorstellen hoe de proporties zijn geweest in de oorspronkelijke staat (Merrillees 2000:183). De foto is vermoedelijk gemaakt door de genootschapsfotograaf Van Kinsbergen, al wordt hij ook aan Woodbury and Page toegeschreven. Andere foto's uit dezelfde periode zijn gemaakt door J.A. Meessen. De Van Kinsbergen-opname is echter van betere kwaliteit. ${ }^{170}$

Over de bouwgeschiedenis zeggen de genootschapsnotulen niet veel. In 1865 werden op suggestie van het bestuurslid N.P. van den Berg nog enkele kleine veranderingen aangebracht, maar deze hadden slechts te maken met het voorterrein en een dakgoot. ${ }^{171}$ Waarom de bouw zo lang duurde, kan men dus niet uit het genootschapsarchief of uit de gedrukte notulen vernemen. Sloet van de Beele vermeldde in zijn overdrachtsdocument van oktober 1866, bestemd voor zijn opvolger Pieter Mijer, dat het ruwe metselwerk gereed was, maar dat 
bestellingen uit Europa de voltooiing vertraagden. ${ }^{172}$ Pas in september 1867 is er sprake van het betrekken van het gebouw: er werd een eerste vergadering gehouden van het bestuur, waarna een bezichtiging plaats vond. We mogen aannemen dat het grotendeels klaar was, maar toch vergaderde het bestuur een maand later weer in het gebouw van de Natuurkundige Vereeniging, waar het vanaf december 1864 steeds was bijeengekomen. Kennelijk was nog niet alles gereed om het bestuur voor zijn maandelijkse vergaderingen voorgoed te huisvesten. Het gebouw in de Rijswijkstraat was na mei 1861 niet meer voor vergaderen gebruikt. Het zou na het vertrek van het genootschap in gebruik worden genomen door het Mijnwezen. Nog weer later zou er het kadaster van Batavia in gevestigd worden. Het zal wel eerst zijn opgeknapt, want zelfs de algemene vergaderingen hadden bij voorzitters of vice-voorzitters thuis plaatsgevonden, zo slecht was langzamerhand het genootschapshuis er aan toe geweest. Op 29 oktober 1867 heette het echter dat het nieuwe gebouw betrokken was. ${ }^{173}$ Over de verhuizing van de verzamelingen horen wij weinig of niets. Vooruitlopend op de overbrenging van de collecties had het bestuur aan de directie van Onderwijs, Eeredienst en Nijverheid voor 1868 een bedrag van $f 2.000$ extra aan subsidie gevraagd, de helft bedoeld voor de aankoop van nieuwe kasten, de andere helft om de verhuizing te bekostigen. ${ }^{174}$

In november 1867 bezocht gouverneur-generaal Mijer, die zelf bij zijn eerdere verblijf in Batavia jarenlang bestuurslid was geweest, het nieuwe gebouw. Hij was het met het bestuur eens dat de beeldengalerij achter de vestibule aangepast moest worden. ${ }^{175}$ De opstelling van de archeologische afdeling voldeed niet. In maart 1868 werd besloten voorlopig van verbouwen af te zien, omdat de behoefte ertoe, gezien de omvang van de verzamelingen, niet groot was. Tijdens deze vergadering besloot het bestuur het museum open te stellen voor publiek: zondag, dinsdag en donderdag van 8.00 tot 12.00 uur. Hiermee kwam het tot een wel heel weinig ceremonieel einde van de bouwgeschiedenis en een begin dat - van de kant van het bestuur - niet getuigde van veel gevoel voor public relations en promotie. ${ }^{176}$ Er vond zelfs geen algemene vergadering van de leden plaats, wat men bij het bereiken van deze mijlpaal in de genootschapsgeschiedenis had mogen verwachten.

Met het Grieks-Dorische, monumentale uiterlijk behoorde het museum tot de grotere openbare gebouwen van Batavia. De bouwstijl paste mooi bij de

172 Sloet van de Beele, 'Overzicht van den staatkundigen toestand van Nederlandsch Indië'.

NA Koloniën 2.10.03 no 24, p. 1485-6.

173 Notulen 5:96, vergadering 29-10-1867.

174 Brieven van het bestuur, 25-5-1867 nr 24 en 16-10-1867 nr 53 in ANRI KBG Dir 0997, pp.

233-4 en 255.

175 Notulen 5:101-2, vergadering 28-11-1867.

176 Notulen 6:18-9, vergadering 8-3-1868. 
grote toegang tot het Europese kerkhof op Tanah Abang (1844), het gebouw van het Hooggerechtshof aan het Waterlooplein (1848) en dat van de ernaast gelegen Loge De Ster van het Oosten (1858). Ook de later gebouwde onderkomens van de Raad van Justitie aan het Stadhuisplein (1870) en het Paleis Koningsplein (1879) passen in de serie van monumentale gebouwen die door het departement van BOW zijn neergezet met een indrukwekkende zuilengalerij naar de straat- of pleinkant. En dan noemen we in dit verband alleen de belangrijkste openbare bouwwerken. De ingenieurs van de waterstaat en van $\mathrm{BOW}$ hadden zo voor een coherent bouwprogramma gezorgd, dat het aanzien van Batavia tot in de twintigste eeuw zou bepalen.

De Koninklijke Natuurkundige Vereeniging, die zo vriendelijk was om jarenlang vergaderruimte af te staan aan het genootschap, had een zwervend bestaan geleid. In 1863 kocht het samen met de Maatschappij van Nijverheid, met wie het al 'samen had gewoond' op Noordwijk, een huis aan Koningsplein-Zuid, aan de andere kant van de weg die het plein omsloot en precies tegenover de droomlocatie van het bestuur van het genootschap. Het was een bestaand huis waarvoor $f 50.000$ was betaald en waar de vereniging in 1950, bij het 100-jarig bestaan, nog steeds in gevestigd was (Willekes Macdonald 1950:20-1). Zo waren er in korte tijd zowel aan de westkant als aan de zuidkant van het plein musea gevestigd, want zowel de vereniging als de maatschappij hield er een museum op na, zij wel onder één dak. Het genootschap was aan het samenwonen ontkomen.

Even weinig als we van de bouwgeschiedenis weten, valt er op basis van de genootschapsnotulen te zeggen over de inrichting. De eerste foto's van het interieur dateren pas van 1878. Wij zouden in die notulen verslagen hebben verwacht over de verdeling van de collecties over de beschikbare ruimtes en over de manier waarop een en ander ging worden opgesteld. Van het pakhuis, waar alles opgepropt stond, kreeg het genootschap de beschikking over duidelijk gescheiden ruimtes, waarbij de verschillende vleugels mogelijkheden boden om per collectie accenten aan te brengen. In plaats van tevreden gesteld te worden met verslagen van discussies of toch minstens verwijzingen naar de verschillende mogelijkheden, vinden we praktisch niets. Tijdens Levyssohn Normans denkbeeldige rondleiding door het gebouw in mei 1865 meldde hij dat het bestuur van plan was in de vestibule de kanonnen op te stellen, die voor de kraton in Martapoera hadden gestaan en die na de val van Bandjarmasin door het gouvernement met de Bandjarmasinse regalia waren overgedragen ter bewaring in het museum. De kanonnen, bekend onder de naam Sri Bandjar, zouden zo de bezoeker imponeren en herinneren aan de Bandjarmasinse krijg (Notulen 3:76-7). Bibliothecaris Stortenbeker adviseerde in januari 1866 de bibliotheek te reorganiseren en tijdschriften en boeken die 'buiten de werkkring des genootschaps' lagen, niet langer aan te houden. In augustus eropvolgend besloot het bestuur om in die zin te handelen en 
de bedoelde werken ook niet meer naar het nieuwe gebouw mee te nemen, maar aan andere geleerde genootschappen over te doen. Tegelijkertijd gaf Stortenbeker een lange lijst op van relevante werken die nog ontbraken. ${ }^{177}$ In 1867-1868 werden kasten, stellingen, rekken besteld, maar zo weinig dat het niet anders kan of men deed het in eerste instantie grotendeels met de oude inboedel uit de Rijswijkstraat. ${ }^{178}$ In maart 1868 vermeldden de notulen wel een bijdrage die fotograaf Van Kinsbergen zou leveren aan de inrichting van het museum. Die nam de uitnodiging van voorzitter Loudon aan om een ontwerp te leveren voor zes nissen in de vestibule, waar vermoedelijk de monumentale boeddha's zouden komen te staan, die nu nog steeds de toeschouwer bij binnenkomst treffen. Van Kinsbergen zou tevens de nieuwe directeur van de gebouwen van het genootschap, Egter van Wissekerke, helpen met het aanbrengen van verbeteringen in de beeldengalerij. ${ }^{179}$ Van Kinsbergen met zijn theaterachtergrond zou zeker een meer dramatische opstelling kunnen leveren van het aanwezige hindoe-beeldenmateriaal. De opstelling van personen op zijn fotografische portretten uit dezelfde periode levert daar het bewijs van. Of Van Kinsbergen en Friederich elkaar bij het rangschikken van de beelden in de weg liepen, zeggen de notulen niet. Friederich was immers twee maanden eerder ook gevraagd zich met de opstelling van de archeologische collectie bezig te houden. Het is eerder waarschijnlijk dat Van Kinsbergen Hoepermans in het museum tegenkwam. ${ }^{180}$

Pas in 1869 was er, naar aanleiding van het rapport van de commissie tot opname van het museum enig zicht op wat er ter discussie stond. ${ }^{181}$ Commissieleden Van der Chijs en L.J.J. Michielsen, de laatste kommies bij de Algemene Secretarie en lid van het genootschap, rapporteerden toen over de stand van zaken in het museum. Zij vonden de metalen platen en stenen met inscripties in het portaal, maar ook de voorwerpen in het midden van de beeldengalerij en in de loods voor grote voorwerpen te laag opgesteld. Zij schonken aandacht aan de lelijke papieren etiketten op de beelden en suggereerden geschilderde nummers of blikken etiketten te gebruiken. Zij stelden ook een herschikking van de beelden voor. Antiek en modern zouden moeten worden gescheiden, alsook Javaans en niet-Javaans. De commissie maakte met geen woord melding van de werkzaamheden van Friederich of Van Kinsbergen in de archeologische galerij. Het blijft een vraag of die zich ooit met de rangschikking van de objecten hebben bemoeid.

ring 1-9-1868); 72 (vergadering 6-10-1868).

179 Notulen 8:19, vergadering 8-3-1868.

180 Notulen 8:10, vergadering 14-1-1868.

181 Notulen 7:22-5, vergadering 6-4-1869. 
Van de etnologische verzameling, waar het geografische indelingscriterium heerste dat ook in Levyssohn Normans catalogus (1868) gevolgd was, vond de commissie dat deze toen al leed onder plaatsgebrek. Het beval uitbreiding van de etnologische zaal aan. De commissie vroeg aandacht voor het probleem van de conservering. Veel van de voorwerpen in deze afdeling waren van niet-duurzame materialen gemaakt. Luchten door de kasten open te zetten was de maatregel waartoe men zich nu beperkte, maar dat was niet genoeg. Restauratie van sommige modellen van huizen werd aanbevolen, terwijl tot de overplaatsing van sommige natuurhistorische voorwerpen naar de collectie van de Koninklijke Natuurkundige Vereeniging werd geadviseerd. Er was wel een lijst van Hoepermans van de oudheidkundige verzameling, maar de eerste gedrukte catalogus ervan zou pas in 1887 worden uitgegeven. De commissie beval tenslotte een catalogus van de manuscripten aan. De opmerkingen van de commissie geven enig inzicht in de problemen waarmee de directeur van het museum, Levyssohn Norman, in het nieuwe gebouw te kampen had.

Het voorstel van de commissie om de etnologische zaal uit te breiden geeft aan dat de nieuwbouw al heel snel niet meer voldeed. Ideeën over uitbreiding werden in 1870 besproken: de commissaris van de gebouwen dacht aan een dwarsgalerij die de linker- en rechtervleugel zou kunnen verbinden, een voorstel, waardoor een vierkant blok zou onstaan. ${ }^{182}$ De binnenplaats zou dan aan vier zijden omsloten worden. Daarvoor werd een plan uitgewerkt waarvoor in 1871 een bedrag van $f 35.000$ werd aangevraagd. Een jaar later werd dat bedrag door Den Haag toegekend. ${ }^{183}$ Nog een jaar zou het duren voordat het bestuur besloot tot de uitvoering van de uitbreiding over te gaan, zij het op een andere wijze. De twee vleugels werden verlengd naar de achterzijde toe en van een dwarsgalerij werd afgezien. ${ }^{184}$ Het museum zou worden voorzien van een aanbouw van acht meter aan de linker bibliotheekvleugel en van 22 meter aan de rechter, etnologische vleugel, waardoor het geheel asymetrisch werd. Achter de leeszaal en de kamer van de bibliothecaris ontstond extra ruimte voor boekenopslag. De grote etnologische zaal werd bijna verdubbeld tot een lengte van 48 bij 16 meter. Er kwamen zuilen bij aan de zijkanten om de eenheid van het geheel te bewaren. ${ }^{185}$ Minder fraai was nu dat de twee vleugels niet meer tot gelijke hoogte in het achterterrein uitstaken.

182 Notulen 8:53, vergadering 3-5-1870.

183 Notulen 9:74, vergadering 7-11-1871;10:136, vergadering 19-11-1872.

184 Notulen 11:11, vergadering 4-2-1873; 37, vergadering 11-3-1873; 41, vergadering 28-3-1873;

128 , vergadering 7-10-1873.

185 In het Gedenkboek van 1878 ziet men deze situatie afgebeeld op de plattegrond van de situatie in 1877. 
Een nieuw begin

Het genootschap was op een lang verwacht moment en op een onverwachte manier aan een nieuw gebouw gekomen. Het relaas van de periode 1857-1861 leest als een somber verhaal. Er leek voor het genootschap niet te ontkomen aan de door de subsidiegever opgelegde fusie, die tegelijkertijd het einde zou betekenen van meer dan tachtig jaar zelfstandig bestaan. Het genootschap kroop echter door het oog van de naald, dankzij het feit dat bouwkundig ingenieur en directeur van BOW in Batavia, Uhlenbeck, tijdens zijn verlof in Nederland minister van koloniën werd en het dossier van het Bataviaasch Genootschap meteen ter hand nam. Hij schoof het idee van een samensmelting van drie verenigingen terzijde. Dat de minister op dat ogenblik in de cultuurman en amateur-wetenschapper, gouverneur-generaal Sloet van de Beele een bondgenoot trof, kwam prachtig uit. Het in zijn voortbestaan bedreigde genootschap kreeg zo een nieuwe kans op een centrale plek aan het Koningsplein. Het kortstondige ministerschap van Uhlenbeck speelde daarbij het genootschap in de kaart.

Het is hier niet de plaats om de bouwgeschiedenis van het museum annex genootschapsgebouw verder te volgen. Dat is eerder op zijn plaats in het vervolg van de geschiedenis, die in 1868 moet aanvangen. Wel opvallend is, dat na al die jaren van wachten en bouwen, het volume zo snel te gering was. Even opvallend is, dat er uit de notulen zo weinig te bespeuren is van de kwalitatieve impuls die men uit het betrekken van een nieuwe gebouw had mogen verwachten. Dat de collecties van de Harmonie naar het Koningsplein verhuisden had aanleiding kunnen geven tot herinventarisatie, waardoor veel aan het licht was gekomen: gebreken, vermissingen, om maar iets te noemen. Alleen de etnologische afdeling kreeg meteen een catalogus, de goede timing daarvan kwam voor rekening van de directeur, Levyssohn Norman. Aan de catalogisering van de archeologische collectie werd gewerkt. Verder werd naar de bibliotheek gekeken: wat moest mee en wat kon weg? Voor het overige is van een herbeschouwing van de collectie, die men bij een andere opstelling in een nieuwe ruimte mocht verwachten, zo goed als niets in de notulen te vinden. De commissie Van der Chijs-Michielsen was in 1869 de eerste die kritisch naar de voorwerpen en naar de opstelling keek en zelfs het verslag van die commissie doet pover aan. Wel is een enkele blik in de notulen vanaf 1868 voldoende om te zien dat de uitbreiding van de collectie voortdurend de aandacht van het bestuur had. Aanwinsten stroomden binnen.

De vraag is of men - de activiteiten van het genootschap vanaf 1861 overziend - positief kan zijn over de manier waarop de verhuizing werd voorbereid. Werden alle kansen waargenomen om over de collectie na te denken? Werden verschillende manieren van presentatie overwogen? Werd gekeken naar hoe andere archeologische en volkenkundige musea het pro- 
bleem van de opstelling hadden opgelost? Uiteraard kunnen we deze vragen niet beantwoorden waar de notulen van het genootschap ons hierop geen antwoord geven. Als we echter naar de andere onderwerpen in deze periode kijken, naast die van nieuwbouw en verhuizing, blijkt het bestuur in de jaren 1861-1868 vooral op het gebied van het verzamelen, op dat van de zorg voor oudheden en taalstudie niet had stilgezeten. Daarmee kon het verdergaan in een tempel aan het Koningsplein. 